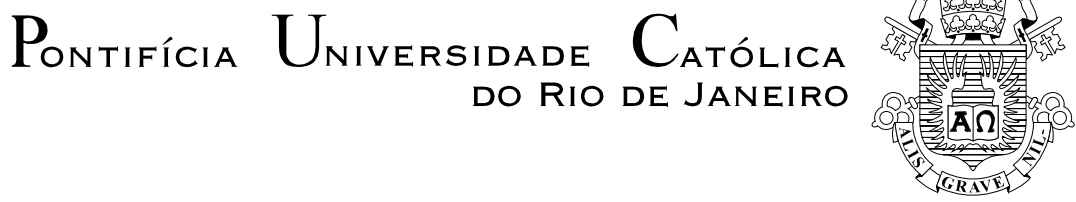

Ana Paula Guida Tavares

A construção do posicionamento do autor na produção textual de alunos do Ensino Médio:

uma análise dos recursos da avaliatividade como estratégias argumentativas

Dissertação de Mestrado

Dissertação apresentada ao Programa de Pós-graduação em Estudos da Linguagem da PUC-Rio como requisitoparcial para obtenção do título de Mestre em Letras/Estudos da Linguagem.

Orientadora: Profa. Adriana Nogueira Accioly Nóbrega

Rio de Janeiro

Abril de 2014 


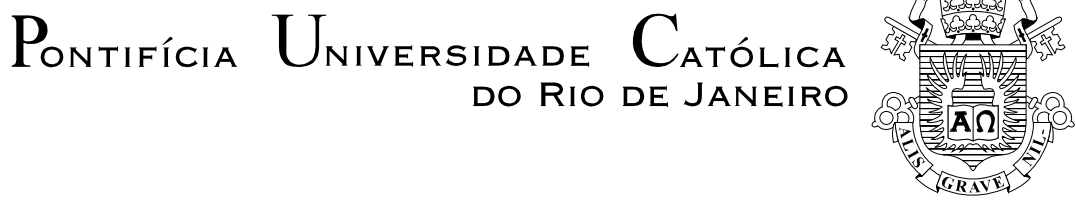

Ana Paula Guida Tavares

\section{A construção do posicionamento do autor na produção textual de alunos do Ensino Médio: uma análise dos recursos da avaliatividade como estratégias argumentativas}

Dissertação apresentada como requisito parcial para obtenção do grau de Mestre pelo Programa de Pós-Graduação em Estudos da Linguagem da PUC-Rio. Aprovada pela Comissão Examinadora abaixo assinada.

Profa. Adriana Nogueira Accioly Nóbrega

Orientadora

Departamento de Letras - PUC-Rio

Profa. Lúcia Pacheco de Oliveira Departamento de Letras - PUC-Rio

Profa. Solange Coelho Vereza

UFF

Profa. Denise Berruezo Portinari Coordenadora Setorial do Centro de Teologia e Ciências Humanas - PUC-Rio 
Todos os direitos reservados. É proibida a reprodução total ou parcial do trabalho sem autorização da universidade, da autora e do orientador.

\section{Ana Paula Guida Tavares}

Graduou-se em Letras, Português e Literaturas de Língua Portuguesa em 2009. Suas áreas de interesse compreendem o estudo da argumentação, a abordagem Sistêmico-Funcional e a produção textual de diferentes gêneros discursivos. Cursou Estudos da Linguagem na PUC-Rio e fez parte, junto à Prof ${ }^{a}$ Dr $^{a}$ Adriana Nóbrega do grupo de pesquisa do projeto Escrita e inclusão social: análise da (re)construção identitária no Ensino Médio. É professora de Língua Portuguesa e de Produção Textual.

Ficha Catalográfica

Tavares, Ana Paula Guida

A construção do posicionamento do autor na produção textual de alunos do ensino médio: uma análise dos recursos da avaliatividade como estratégias argumentativas / Ana Paula Guida Tavares ; orientador: Adriana Nogueira Accioly Nóbrega. $-2014$.

151 f. ; $30 \mathrm{~cm}$

Dissertação (mestrado) - Pontifícia Universidade Católica do Rio de Janeiro, Departamento de Letras, 2014.

Inclui bibliografia

1. Letras - Teses. 2. Linguística sistêmico-funcional. 3. Avaliatividade. 4. Argumentação. 5. Gêneros discursivos. 6. Produção textual. 7. Posicionamento do autor. 8. Ensino médio. I. Nóbrega, Adriana Nogueira Accioly. II. Pontifícia Universidade Católica do Rio de Janeiro. Departamento de Letras. III. Título. 
Para os meus pais, Antonio (in memorian) e Ivete, pelo exemplo e força. Para o meu marido, Gabriel, por tudo o que representa para mim. 


\section{Agradecimentos}

À minha orientadora, competente e querida, Professora Adriana Nogueira Accioly Nóbrega, pelo exemplo de extrema generosidade e estímulo em todos os momentos, por não me deixar desistir e pela parceria para a realização deste trabalho. Muito obrigada!

À Capes e à PUC-Rio, pelos auxílios concedidos, sem os quais este trabalho não poderia ter sido realizado.

Ao meu amado afilhado, Matheus, pelo interesse neste trabalho durante todo o percurso.

Aos meus irmãos, Kátia e Marcio, pelo carinho.

Aos meus pais, pela educação, dedicação e amor de todas as horas.

Ao meu marido, sem o qual nada seria possível ou estimulante nem tampouco prazeroso. Sua paciência e dedicação foram essenciais durante todo esse processo.

Aos meus colegas da PUC-Rio.

Aos professores que participaram da Comissão Examinadora.

A todos os professores e funcionários do Departamento, pelos ensinamentos e pela ajuda.

A todos os amigos e familiares que, de uma forma ou de outra, estimularam essa caminhada. 


\section{Resumo}

Guida Tavares, Ana Paula; Nóbrega, Adriana Nogueira Accioly (Orientadora). A construção do posicionamento do autor na produção textual de alunos do Ensino Médio: uma análise dos recursos da avaliatividade como estratégias argumentativas. Rio de Janeiro, 2014. 151p. Dissertação de Mestrado - Departamento de Letras, Pontifícia Universidade Católica do Rio de Janeiro.

O objetivo deste estudo é investigar a construção do posicionamento autoral em textos dissertativo-argumentativos produzidos por alunos do Ensino Médio, reconhecendo esta prática discursiva como espaço sociossemiótico de elaboração de estratégias argumentativas e negociação de significados. Considerando a escrita como atividade consciente, planejada, pensada e repensada, a presente pesquisa tem como suporte teórico: a perspectiva de linguagem proposta pela Linguística Sistêmico-Funcional (Halliday e Hassan, 1989; Halliday e Matthiessen, 1999; Eggins, 2004; Gouveia, 2009); o Sistema da Avaliatividade (Martin e White, 2005; Vian Jr, 2002); o estudo de Gêneros (Martin, 1992; Bakhtin, 1992; Miller, 1994) e teorias de Argumentação (Breton, 1999; Abreu, 2003). Textos dissertativo-argumentativos elaborados por alunos do terceiro ano do Ensino Médio, que simulam redações propostas em exames de vestibular, foram selecionados para a investigação da construção do posicionamento do autor. Os resultados indicam que recursos da Avaliatividade operam como potencializadores da construção do posicionamento do autor, atuando como possíveis estratégias argumentativas. Como contribuição teórica, a análise dos dados sugere uma estreita relação entre o "potencial de significados" da linguagem e o "potencial argumentativo" de um texto, realizada através de escolhas semânticas e lexicais aliadas a estratégias argumentativas, que resultam em "potenciais de significados argumentativos". Logo, de acordo com este estudo, é possível tecer um paralelo entre a abordagem de linguagem proposta pela Linguística Sistêmico-Funcional e o estudo da argumentação. Implicações do estudo apontam para a latente necessidade de fazermos uso da abordagem SistêmicoFuncional e da Avaliatividade em sala de aula, no ensino-aprendizagem de Língua Portuguesa, principalmente no que se refere à Produção Textual.

\section{Palavras chave}

Linguística Sistêmico-Funcional; avaliatividade; argumentação; gêneros discursivos; produção textual; posicionamento do autor; ensino médio. 


\section{Abstract}

Guida Tavares, Ana Paula; Nobrega, Adriana Nogueira Accioly (Advisor). The construction of authorial positioning in secondary school written production: an analysis of appraisal resources as argument strategies. Rio de Janeiro, 2014. 151p. MSc Dissertation - Departamento de Letras, Pontifícia Universidade Católica do Rio de Janeiro.

The purpose of this study is to investigate the construction of authorial positioning in written argumentative texts produced by $12^{\text {th }}$ grade students, regarding this discursive practice as a social semiotic space for creating strategies of argumentation and meaning negotiation. Considering writing as a conscious, planned and carefully thought activity, this research is theoretically supported by: the language perspective proposed by Systemic Functional-Linguistics (Halliday e Hassan, 1989; Halliday e Matthiessen, 1999; Eggins, 2004; Gouveia, 2009); the Appraisal System (Martin e White, 2005; Vian Jr, 2002); Genres Studies (Martin, 1992; Bakhtin, 1992; Miller, 1994) and theories of Argumentation (Breton, 1999; Abreu, 2003). Argumentative texts written by $12^{\text {th }}$ grade students, which simulate compositions proposed in university entrance exams, were selected in order to investigate the construction of authorial positioning. Results indicate that Appraisal resources enhance the argumentative potential in the construction of authorial positioning, acting as possible strategies in the argumentation process. Considering the theoretical contribution, data analysis suggests a close relationship between language "meaning potential" and text "argumentative potential", which are realized through semantic and lexical choices and are related to strategies of argumentation that result in "argumentative meaning potentials". Therefore, according to this study, it is possible to create a parallel between the language perspective proposed by Systemic Functional-Linguistics and studies of argumentation. Implications of the study point to the latent necessity of using the Systemic-Functional and Appraisal frameworks in the classroom, in the teaching-learning of Portuguese Language, mainly in relation to the Written Production.

\section{Keywords}

Systemic-Funcional Linguistics; appraisal; argumentative texts; genre; written production; authorial positioning; secondary school. 


\section{Sumário}

1. Introdução 12

2. Pressupostos Teóricos $\quad 19$

2.1. A abordagem sociossemiótica de linguagem 19

2.1.2. O contexto, o texto e as realizações da linguagem 23

2.2. Sistema da Avaliatividade 28

2.2.1. Atitude 30

2.2.2. Engajamento 34

2.2.3. Gradação 39

2.3. Gêneros Discursivos e a Redação de Vestibular 41

2.4. Argumentação 47

3. Metodologia $\quad 55$

3.1. Pressupostos metodológicos $\quad 55$

3.2. Contexto e corpus 58

3.3. Geração de dados 63

$\begin{array}{ll}\text { 3.4. Participantes da pesquisa } & 67\end{array}$

3.4.1. Autores 67

3.4.2. Professora, pesquisadora e banca 68

3.5. Procedimentos de pesquisa e categorias de análise 70

4. Análise dos Dados $\quad \mathbf{7 5}$

4.1. A Gradação como elemento potencializador do posicionamento e da argumentação $\quad 76$

4.2. Apreciação e Julgamento - recursos opinativos na construção
do posicionamento autoral

4.3. O Engajamento - estratégias para a concessão de força ao posicionamento e à argumentação 100

$\begin{array}{ll}\text { 4.4. Reflexões } & 117\end{array}$

5. Considerações Finais 121

6. Referências bibliográficas $\quad 128$

$\begin{array}{ll}\text { Anexos } & 132\end{array}$ 


\section{Lista de figuras}

Figura 1 - Representação da realização dos níveis linguísticos e extralinguísticos

Figura 2 - Variáveis do Contexto e Significados $\quad 24$

Figura 3- Metafunções e seus respectivos sistemas de significados 27

Figura 4 - Sistema da Avaliatividade $\quad 29$

Figura 5 - Resumo de Categorias de Afeto 30

Figura 6 - Resumo de Categorias de Julgamento correlatas à Modalidade

Figura 7 - Resumo de Categorias de Julgamento 31

Figura 8 - Resumo de Categorias de Apreciação 33

Figura 9 - Resumo dos recursos de Engajamento 38

Figura 10 - Categorias da Gradação $\quad 40$

Figura 11 - Diferenças contextuais do gênero 45

Figura 12 - Potencial de Posicionamentos 53

Figura 13 - Divisão de Turmas 62

Figura 14 - Redações por título, turma e ordem em que aparecem na análise dos dados

Figura 15 - Agrupamento de redações por categoria de análise 73

Figura 16 - Categorias - análise pela gradação 76

Figura 17 - Recursos opinativos e críticos na construção do percurso argumentativo e do posicionamento do autor 100

Figura 18 - Continuum de força na argumentação e no posicionamento autoral 


\section{Anexos}

Anexo 1 - Redação 1. Título: Canetas e inclusão social 132

Anexo 2 - Redação 2. Título: A importância da leitura e seus reflexos

Anexo 3 - Redação 3. Título: A escrita social 134

Anexo 4 - Redação 4. Título: O ciclo da cultura 135

Anexo 5 - Redação 5. Título: A importância da escrita 136

Anexo 6 - Redação 6. Título: O caminho para entrar na sociedade 137

Anexo 7 - Redação 7. Título: Educação e evolução 138

Anexo 8 - Redação 8. Título: Escrever bem é o produto da leitura 139

Anexo 9 - Redação 9. Título: A importância da escrita 140

Anexo 10 - Redação 10. Título: Chave para o conhecimento 141

Anexo 11 - Redação 11. Título: Inclusão social 142

Anexo 12 - Redação 12. Título: O valor atemporal do ensino sistemático

Anexo 13 - Redação 13. Título: Os reflexos positivos da capacidade de escrita

Anexo 14 - Redação 14. Título: Inclusão e escrita 145

Anexo 15 - Redação 15. Título: Objetivos pelo estudo 146

Anexo 16 - Proposta de Redação - Tema 147

Anexo 17 - Autorização de Pesquisa - Do colégio 148

Anexo 18 - Autorização de Pesquisa - Dos responsáveis 149

Anexo 19 - Autorização de Pesquisa - Dos participantes 150

Anexo 20 - Matriz de Competências para a Redação do ENEM 151 
"Não podemos ensinar a criatividade - como se tornar um bom escritor. Mas podemos ajudar um jovem escritor a descobrir, dentro de si próprio, que tipo de escritor ele gostaria de ser."

Mario Vargas Llosa 


\section{Introdução}

Eu me interesso pela linguagem porque ela me fere ou me seduz. Roland Barthes (2002, p.47)

O objetivo deste estudo é investigar a Produção Textual, mais precisamente, a construção do posicionamento do autor em textos dissertativoargumentativos. Entender mais sobre as formas de construção do posicionamento é, para mim, compreender o movimento de ser autor e se apropriar das palavras para construir valores.

A escrita é indispensável para a formação de indivíduos incluídos socialmente e estudar o discurso é fundamental para que possamos compreender tudo o que envolve a vida em sociedade. Desde que o ser humano começou a organizar o pensamento por meio de registros sistemáticos, a escrita foi se desenvolvendo e adquirindo extremo valor nas relações sociais, na disseminação de informações e ideologias.

O interesse que tenho pela produção textual está profundamente relacionado a minha experiência profissional, mas mesmo antes disso, como aluna de Ensino Médio, eu também lutei com e contra a produção de textos do tipo dissertativo-argumentativo que assombravam o meu ano de vestibular.

Ainda nos primeiros anos como docente, percebi que este assombro também fazia parte da vida dos meus alunos, e, neste momento, começaram a surgir minhas primeiras reflexões pedagógicas sobre a prática e a apropriação da escrita por estes autores.

Desde os primeiros momentos como professora, pude constatar uma realidade que ecoa nas salas de aula de formação de profissionais do magistério sobre a situação da educação no Brasil, a realidade socioeconômica do país reflete-se na escola, nas figuras angustiadas do professor e do aluno, na cobrança de modelos de ensino ultrapassados, tantos aspectos que permeiam a vida das pessoas envolvidas com educação.

À medida que pensava nestes problemas, mais constatava a necessidade de pesquisar a respeito da prática do ensino de Produção Textual, por acreditar que 
quando escrevemos também nos inscrevemos no texto, nos afiliamos com ideais, entalhamos nossos valores, esculpimos nossos princípios e gravamos nossas digitais como autores nos textos. Segundo Jean Grenier, filósofo e escritor francês, "Escrever é pôr em ordem as nossas obsessões”1, e, para mim, a prática da produção textual está profundamente relacionada à maneira como organizamos nossos valores e como nos inserimos na sociedade, na história e no mundo. A escrita proporciona mais do que integrar e fazer parte da sociedade, através dela é possível identificar a maneira como os autores querem ser vistos pela e na sociedade.

O ensino de Produção Textual tem grande relevância no cenário educacional, pois o aprendizado da escrita abarca muito mais do que as noções e compreensão das letras e a maneira como conectá-las, mas a oportunidade de fazer uso desta competência com autonomia, de modo a proporcionar ao alunoautor $^{2}$ a chance de se incluir socialmente.

Quando tratamos da autonomia do escritor é necessário atentar para a questão do posicionamento do autor. Entendo que o aluno é capaz de escrever, ainda que cometa transgressões quanto ao gênero discursivo e às regras da Gramática Formal, mas, de que maneira a produção dos discentes é construída, como se posicionam, o que envolve este posicionamento, quais são os recursos que os alunos podem dispor para a construção dos seus pontos de vista? O que há por trás das palavras e da organização de um texto?

Investigar a construção do posicionamento do autor, nos textos dos alunos, nos permite observar a maneira como ele aprecia, avalia, critica, julga e analisa o que o cerca. Para isso, nada melhor do que o movimento argumentativo dos textos dissertativos do gênero Redação de Vestibular (ou no caso desta pesquisa, mais precisamente textos que são uma simulação da Redação de Vestibular). Quando argumentamos, defendemos nossos pontos de vista e nos posicionamos e, segundo Breton (2003, p.37), a opinião é definida pelo “conjunto das crenças, dos valores, das representações do mundo e das confianças que um indivíduo forma para ser ele próprio".

\footnotetext{
${ }^{1}$ Disponível em: http://www.citador.pt/frases/citacoes/a/jean-grenier. Acesso em: 04 mar. 2014.

${ }^{2}$ Os termos 'autor', 'aluno' e 'escritor' não estão sendo utilizados aqui como uma forma de identificar os participantes desta pesquisa como pertencentes do sexo masculino apenas. Faço uso do termo de forma genérica. Portanto, tal forma compreende autor e autora, aluno e aluna, escritor e escritora.
} 
Neste contexto, surge a necessidade de observarmos a construção do posicionamento autoral. O interesse de compreender como os alunos se inscrevem nos textos, como autores, como constroem seus posicionamentos e revelam seus pontos de vista, se origina na concepção da escrita como uma atividade que deve ser consciente e do reconhecimento desta prática discursiva como espaço sociossemiótico de elaboração de estratégias argumentativas e de negociação de significados.

O que motiva este trabalho é a crença de que nós, professorespesquisadores, devemos pesquisar sobre aquilo que nos provoca e estimula. Vejo que a investigação leva à reflexão, e a reflexão pode trazer novos olhares, questões, alternativas, possibilidades, escolhas e contribuições que auxiliam o crescimento pessoal e profissional. Minha experiência profissional é predominante na área de produção textual, mais precisamente no ensino de produção de textos do tipo dissertativo-argumentativo para o terceiro ano do Ensino Médio, concentrando este tipo de texto quase sempre no gênero Redação de Vestibular. Seguramente, há muitas características próprias do gênero Redação de Vestibular que são refletidas nas "grades de correção"” elaboradas pelas bancas dos concursos, mas é importante citar que neste trabalho não estou interessada em corrigir ou tratar os desvios e/ou acertos dos textos dos alunos, portanto, esta pesquisa não tem o objetivo de observar a realização da língua de acordo com a visão da Gramática Formal.

Sabemos que a Gramática Formal tem bastante espaço nas aulas de Língua Portuguesa, já o ensino de Produção Textual nem sempre tem o devido valor nos contextos de ensino, já que, muitas vezes, como reconhecido através da vivência de sala de aula, a prática da produção de textos é feita de maneira engessada e orientada apenas para uma única situação comunicativa específica. Diante deste cenário, surgem dúvidas sobre como os alunos se posicionam a respeito do ensino da escrita na escola. Há o reconhecimento da prática da escrita como uma ferramenta que pode levar o autor a alcançar outros propósitos comunicativos? A escrita é importante para a inclusão social? Estas dúvidas deram origem ao tema

\footnotetext{
3 Grade de Correção é um termo geralmente utilizado para designar as características que determinado tipo de texto deve ter para ser considerado um texto pertencente a um tipo e um gênero determinado, as grades orientam as correções das redações de vestibular e determinam a pontuação que um candidato pode alcançar se cumprir todas as características necessárias ao texto.
} 
da redação ${ }^{4}$ proposta aos alunos, autores dos textos que foram analisados neste trabalho.

Como dados da presente pesquisa foram utilizadas redações de alunos do Ensino Médio de uma instituição de ensino localizada na cidade do Rio de Janeiro. Tais redações, produzidas em um contexto real de sala de aula, foram selecionadas por acreditar em uma visão sociodiscursiva e sociossemiótica em que autores e contexto de produção são levados em consideração, e por entender que a apropriação da escrita é responsável pela inclusão dos alunos na sociedade, ainda que faltem recursos ao professor para que o ensino desta modalidade de uso da linguagem seja feita de maneira a contemplar outras situações comunicativas que não apenas o contexto escolar.

Proponho a análise investigativa baseada no paradigma funcional, com a proposta de observar os textos de acordo com a abordagem da Linguística Sistêmico-Funcional (Halliday e Hassan, 1989; Halliday e Matthiessen, 1999; Eggins, 2004; Gouveia, 2009) e o Sistema da Avaliatividade, Appraisal System, (Martin e White, 2005; Vian Jr, 2010), e sugiro, também, que as práticas docentes de Produção Textual sejam examinadas de uma maneira a contemplar tais fundamentos, já que escrever deve figurar além das regras gramaticais impostas por qualquer sistema teórico, pois o movimento autoral é uma oportunidade de oferecer um determinado posicionamento para o mundo e manifestar valores e experiências do escritor, no espaço do texto e para outros espaços discursivos.

Alguns estudos nesta área têm sido desenvolvidos ao longo dos anos (Caldeira, 2006; Nóbrega, 2009; Ramos, 2011; Vian Jr, 2010; Wilson, 2008) e muito têm contribuído para os estudos de linguagem. Situo este trabalho no campo pedagógico por considerar a prática de ensino e as implicações resultantes dela e, principalmente, no campo linguístico, por analisar tais fenômenos à luz da perspectiva de linguagem proposta pela Linguística Sistêmico-Funcional (Halliday e Hassan, 1989; Halliday e Matthiessen, 1999; Eggins, 2004; Gouveia, 2009), doravante LSF, em interface com o Sistema da Avaliatividade (Martin e White, 2005; Vian Jr, 2010); a abordagem de Gêneros Discursivos (Martin, 1992; Bakhtin, 1992; Miller, 1994) e os estudos de Argumentação (Breton, 1999; Abreu, 2003).

\footnotetext{
${ }^{4}$ A proposta de redação encontra-se nos Anexos deste trabalho (cf. Anexo 16, p. 142).
} 
Esta pesquisa pretende contribuir para os estudos da linguagem por considerar os participantes, suas intenções, posicionamentos e valores, o contexto cultural que compreende o conjunto de relações de sentidos resultantes da sociedade, e o contexto situacional que cerca os autores.

Como mencionado anteriormente, o objetivo deste trabalho é investigar a maneira como é construído o posicionamento do autor. Para tanto, serão usados os parágrafos introdutórios das redações produzidas pelos participantes desta pesquisa, pois, tradicionalmente, são nestes parágrafos que a tese se consolida e o posicionamento geralmente é mais forte. Assim, trago três questões de pesquisa:

- De que forma o posicionamento do autor é expresso nos parágrafos introdutórios dos seus textos?

- De que maneira o uso dos recursos da Avaliatividade podem ser vistos como possíveis estratégias de argumentação?

- Que potenciais de significados argumentativos podem ser criados através dos recursos da Avaliatividade?

Para auxiliar a compreender as questões que orientam esta pesquisa, três categorias de análise são propostas com o intuito de examinar: (1) a Gradação como elemento potencializador do posicionamento do autor e da argumentação; (2) o Julgamento e a Apreciação como recursos opinativos na construção do posicionamento autoral; e (3) o Engajamento como recurso de concessão de força ao posicionamento e à argumentação.

O trabalho está dividido em seis capítulos. Após esta introdução, no capítulo 2, serão apresentados os pressupostos teóricos que fundamentam a pesquisa, e subdividem-se em quatro momentos.

O primeiro momento diz respeito à Linguística Sistêmico-Funcional, que concebe a linguagem no plano linguístico e extralinguístico e a compreende como um sistema de construção de significados (Halliday, 1994), partindo de contextos reais de produção, em que partilhamos escolhas paradigmáticas, intencionais ou não, feitas em meio a múltiplas oportunidades que o sistema oferece. São explicitadas, também, as noções de gêneros discursivos na visão da Nova Retórica de Miller (1984), que considera o gênero como a ação social e ressalta a importância do contexto, e na visão teleológica de Martin (1992), que entende o 
gênero como um sistema estruturado em partes, com meios específicos e para fins específicos. Articulo teoricamente tais fundamentos aos recursos do Sistema da Avaliatividade (Martin e White, 2005), que oferece uma proposta de análise textual capaz de identificar a maneira como indivíduos adotam posicionamentos e valores e negociam significados. Por último, apresento os aspectos da Argumentação, oferecendo subsídios para que possamos observar estratégias de persuasão, expressas no texto, por meio de argumentos, que se somam para sustentar a análise dos textos deste trabalho.

Veremos detalhadamente, ainda no capítulo 2, que há uma relação sugerida neste estudo entre "potencial de significados de linguagem" e o “potencial de significados argumentativos” de um texto, que se inscreve em um “potencial de posicionamentos” do autor. Proponho que o autor seleciona para o seu texto um potencial de significados de linguagem, que parte de escolhas sistêmicas de múltiplas possibilidades de acessos a diferentes sistemas semióticos, e um potencial de significados argumentativos, que é construído de acordo com as escolhas de estratégias argumentativas para criar um determinado posicionamento.

Em seguida, no capítulo 3, indico os pressupostos metodológicos que foram utilizados para o desenvolvimento e análise dos textos; o contexto no qual foi desenvolvida a pesquisa; situo e comento o tema da redação que deu origem aos dados analisados; apresento mais detalhadamente os participantes e encerro com os procedimentos de pesquisa e as categorias de análise já citadas anteriormente.

A análise dos dados encontra-se no capítulo 4, que pretende responder às questões de pesquisa apresentadas nesta introdução, e subdivide-se em três etapas, sendo a primeira voltada à observação do recurso da Gradação como potencializador do posicionamento do autor e da argumentação; a segunda concentra-se na análise do Julgamento e da Apreciação como recursos opinativos na construção do posicionamento do autor e, por fim, a última etapa relaciona-se aos recursos do Engajamento para concessão de força ao posicionamento, observando o percurso argumentativo das vozes de um texto. Além disso, concluo o capítulo 4 com algumas reflexões sobre os resultados da análise dos textos.

O capítulo 5 destina-se às considerações finais e contempla uma reflexão acerca das perguntas que nortearam o desenvolvimento desta dissertação propondo a discussão acerca da contribuição teórica deste trabalho que sugere 
uma interface de diálogo entre as teorias; e apresenta as implicações pedagógicas; contribuições e limitações da pesquisa e futuros encaminhamentos para este estudo.

Finalmente, no capítulo 6, disponibilizo as referências bibliográficas que apoiaram esta produção e os anexos que compreendem a proposta de redação utilizada nesta análise e das produções textuais dos autores na íntegra e os documentos para autorizações de uso dos textos, concedidas pelos alunos e por seus responsáveis legais. 


\title{
2
}

\section{Pressupostos Teóricos}

\begin{abstract}
A linguagem que eu falo em mim mesmo não é de meu tempo; esta exposta, por natureza, à suspeita ideológica; é, portanto, com ela que é preciso que eu lute. Escrevo porque não quero as palavras que encontro: por subtração.
\end{abstract}

Roland Barthes (2002, p.49)

Neste capítulo, será apresentada a fundamentação teórica de linguagem que contribuirá para o desenvolvimento desta pesquisa. Para observar aspectos da linguagem, dos gêneros discursivos, o processo argumentativo e o posicionamento do aluno é preciso uma teoria que dê conta de diversas circunstâncias que cercam a produção textual. Ao lado da Linguística Sistêmico-Funcional, pretendo trabalhar com noções de gêneros discursivos, recursos do Sistema da Avaliatividade e, também, aspectos da Argumentação.

Portanto, este estudo contempla uma fundamentação teórica construída de maneira que, sistematicamente e por meio da linguagem, seja possível examinar os textos do corpus da pesquisa, através de uma metodologia de análise que contemple o texto e o contexto, ambos vivos e fruto de relações, intenções, histórias e múltiplos sentidos, além de ser possível observar como os indivíduos usam a língua e como ela pode ser estruturada de diferentes maneiras para produzir significados distintos.

\section{1}

\section{A abordagem sociossemiótica de linguagem}

O objetivo principal das análises que emergem da abordagem sociossemiótica de linguagem proposta pela Linguística Sistêmico-Funcional (LSF) perpassa o caráter do significado de como, onde, porque e para quem o indivíduo utiliza a língua. Nessa teoria, é o significado que determinará a forma que a linguagem apresentará e não é possível conceber o uso da língua em um 
contexto diferente daquele em que foi produzida sendo que o ponto de partida para qualquer análise Sistêmico-Funcional é o texto.

A Linguística Sistêmico-Funcional é considerada:

a) uma teoria social, por partir da sociedade e do uso da linguagem que é feito pelos indivíduos (Hawad, 2002);

b) semiótica, por preocupar-se com todas as formas de manifestações da linguagem, considerando semiótica o estudo dos significados (Halliday e Hassan, 1989);

c) funcional, por ter interesse nos objetivos e razões pelas quais os indivíduos fazem uso da linguagem (Eggins, 2004; Meurer, 2006);

d) semântica, porque toda interação dentro de um contexto específico possui um significado oriundo de processos textuais da vida social (Moura Neves, 2004; Eggins, 2004); e

e) contextual, já que contempla aspectos do processo de comunicação humana, da relação entre indivíduos e sociedade, e, conforme Halliday (1994), a linguagem é produto do processo social.

Segundo Eggins (2004, p.2), a Linguística Sistêmico-Funcional é “uma abordagem interpretativa e descritiva que possibilita entendermos a linguagem como um recurso estratégico e criador de sentidos”, e, além disso, é uma abordagem que investiga "como as pessoas usam a linguagem umas com as outras, objetivando realizar sua vida social cotidiana” (Eggins, 2004, p.3).

Ainda de acordo com Eggins (2004):

- O uso da linguagem é funcional;

- A função da linguagem é criar significados;

- Estes significados são influenciados pelo contexto social e cultural nos quais são trocados (negociados);

- O processo de usar a linguagem é um processo semiótico, um processo de criar significados através da possibilidade de diferentes escolhas.

Trata-se, dessa maneira, de uma teoria que nos permite identificar, por meio da linguagem, características dos indivíduos produtores de textos, da sociedade, da cultura e do contexto, através de métodos detalhados e sistemáticos 
de análise da linguagem, já que é através dela que os indivíduos revelam seus valores, seus pensares, sua cultura e sua história.

A Linguística Sistêmico-Funcional (Halliday e Hasan, 1989; Martin, 1992; Halliday e Matthiessen, 2004; Unsworth, 2000; Eggins, 2004) considera a linguagem a partir de textos reais, frutos de produções legítimas, para analisar fenômenos sociais e aspectos dos indivíduos, produtores de textos, tais como seus próprios valores e representações de mundo, em contextos reais, levando em conta aspectos internos e externos ao texto. Desse modo, a LSF permite a esta pesquisa uma análise concreta e efetiva dos textos, interações construídas na e pela linguagem.

A linguagem aqui é concebida como um sistema semiótico em três estratos linguísticos: o semântico-discursivo (nível do significado), o de fraseados (no nível da oração, realizado pela lexicogramática) e outro de letras e sons (nível grafo-fonológico). Além disso, há o nível extralinguístico que abarca dois estratos: o contexto de cultura, que envolve amplamente os sentidos que podem emergir de uma determinada cultura, e o contexto de situação, que é particular de cada interação, comentados, mais detalhadamente, adiante. Cada estrato é materializado em um subsequente e há o sentido de interdependência entre os níveis como, a seguir, é identificado na Figura 1:

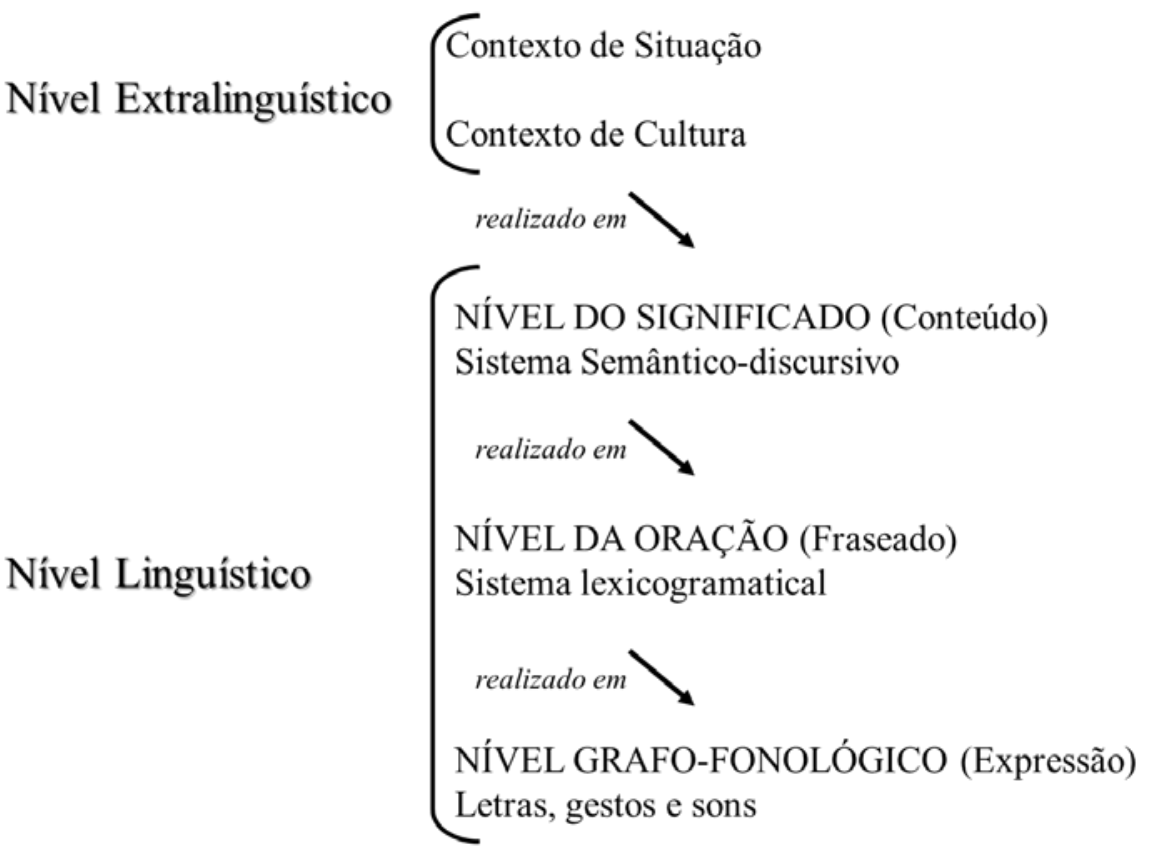

Figura 1 - Representação da realização dos níveis linguísticos e extralinguísticos (adaptado de Gouveia, 2009). 
Imbricados no texto há um sistema linguístico, de recursos lexicogramaticais que realizam o nível semântico, e também há um sistema social, e podemos entender que o sistema é todo o potencial de significado que será instanciado pelo texto.

Considerando a linguagem como um sistema de construção de significados (Halliday, 1994), a maneira como os falantes fazem uso dela em contextos reais de produção requer o entendimento de que há um sistema de escolhas paradigmáticas, intencionais ou não, que o sujeito faz em meio a múltiplas oportunidades que o sistema oferece. Conforme apontado por Halliday:

(...) a teoria sistêmica é uma teoria de significados a partir de escolhas, através da qual a linguagem, ou qualquer outro sistema semiótico, é interpretado como redes de opções encadeadas: "ou isto, ou aquilo, ou o outro", "ou mais como este, ou mais como o outro", e assim por diante. Aplicada à descrição de linguagem, isto significa começar com as características mais gerais e proceder passo a passo até se tornar sempre mais específico. (Halliday, 1994, p. xiv)

Tais escolhas são negociadas pelo falante a partir do uso e do contexto específico em que ocorre a interação comunicativa. De acordo com Moura Neves (2004), a função pode ser considerada a partir das relações entre a língua e o contexto, considerando-se as interações sociais. Para a autora:

(...) as relações (ou funções) entre a língua como um todo e as diversas modalidades de interação social, (...) frisam, assim, a importância do papel do contexto, em particular do contexto social, na compreensão da natureza das línguas. (Moura Neves, 2004, p.41)

Esta pesquisa se alinha com os pressupostos da LSF que oferecem um olhar multifuncional da linguagem (Halliday e Hasan, 1989), e a visão de Halliday (1994) de que a linguagem é um instrumento de interação social, que tem como objetivo a comunicação e a transmissão de informação. A teoria da LSF oferece à presente pesquisa essenciais ferramentas de análise de dados, considerando-se contexto, função e situações reais de uso da língua. Por isso, os fundamentos teóricos da LSF são relevantes para este trabalho por:

- considerarem os aspectos funcionais;

- basearem-se em aspectos semânticos;

- proporem a interação e o contexto; 
- fundamentarem-se em aspectos semióticos capazes de criar significados.

A linguagem é um instrumento de interação social e um processo de produção de sentidos que emergem de textos vivos, reais, e os significados possuem funções adquiridas no uso da linguagem. Logo, analisar os textos em seus contextos de produção, as escolhas paradigmáticas que envolvem a produção de sentidos e compreender o 'potencial de significados' (Martin e White, 2005, p.24) pode contribuir, e muito, para maiores entendimentos sobre o posicionamento autoral no texto dissertativo-argumentativo, como proposto neste trabalho.

É importante reforçar que neste trabalho vejo a linguagem como um potencial de significados que partem de escolhas sistêmicas e privilegiam as múltiplas possibilidades de acessos a diferentes sistemas semióticos que um autor dispõe na construção de determinados significados particulares.

Para a LSF, o uso da linguagem perpassa questões de escolhas paradigmáticas, que são orientadas em função de nossos interesses comunicativos, anseios e desejos de criar determinados significados. Assim, textos terão características distintas que serão assumidas de acordo com a finalidade que os participantes tenham.

Na seção a seguir, observaremos a relação entre o texto e o contexto no uso da linguagem e as realizações lexicais que emergem das seleções paradigmáticas feitas pelos alunos em seus textos. Tal abordagem será essencial na investigação do posicionamento do aluno nos textos dissertativoargumentativos.

\subsection{2}

\section{O contexto, o texto e as realizações da linguagem}

Da relação entre indivíduo e sociedade partem aspectos centrais a todas as teorias sociais. O antropólogo Bronislaw Malinowski (1935) considera o contexto um elo intermediário entre a situação e o linguístico e desenvolve os conceitos de contexto de situação e contexto de cultura. A partir das ideias do autor, também para a LSF há que se considerar o "contexto” como o que é parte das relações humanas dentro de uma dada sociedade ou 'o ambiente total onde um texto se 
desenvolve' (Halliday e Hasan, 1989, p. 10). Segundo Hawad (2002, p. 40), "Linguagem e sociedade são uma concepção unificada, e precisam ser investigadas e compreendidas como um todo: não há homem social sem linguagem, e não há linguagem sem homem social”.

O contexto de situação está vinculado ao registro propriamente dito, mas é a partir dos elementos da cultura e da situação de fala que o indivíduo é capaz de fazer escolhas próprias de um contexto, situando o texto sociohistoricamente dentro de uma cultura específica, considerando, desta maneira, o contexto de cultura.

Todo contexto está relacionado a variáveis que podem mudar de acordo com o que é expresso (campo), por quem é expresso (relações), ou como é expresso (modo).

A noção de instanciação explicita a relação entre o sistema linguístico e o texto, isto é, o sistema é instanciado, através da linguagem que realiza o contexto, na forma de texto. Desta forma, o campo refere-se à razão pela qual a interação acontece; as relações contemplam os papeis desempenhados pelos participantes do contexto e também as relações interpessoais no discurso; o modo está relacionado à maneira como a língua é organizada para atingir objetivos específicos.

As três variáveis do contexto serão realizadas pelos significados ideacional, interpessoal e textual, segundo a figura abaixo:

\begin{tabular}{|c|c|}
\hline VARIÁVEL DO CONTEXTO & SIGNIFICADO \\
\hline Campo & $\begin{array}{c}\text { O significado ideacional, em que são levadas em } \\
\text { consideração as escolhas dos falantes para externar sua } \\
\text { experiência de mundo, sua realidade e vivência. }\end{array}$ \\
\hline Relações & $\begin{array}{c}\text { O significado interpessoal, que contempla as relações e } \\
\text { os papeis que os participantes de uma interação atribuem } \\
\text { a si e aos outros. }\end{array}$ \\
\hline Modo & $\begin{array}{c}\text { O significado textual, em que a distribuição da } \\
\text { informação na mensagem e a própria maneira de } \\
\text { construíla são observadas. }\end{array}$ \\
\hline
\end{tabular}

Figura 2 - Variáveis do Contexto e Significados. 
No caso da análise proposta neste estudo, esses elementos do contexto evidenciam a interação do universo do aluno no texto e pode oferecer um rico material do estudo do posicionamento autoral por meio da linguagem. Considerando-se a escrita uma atividade que deve ser consciente, planejada, pensada e repensada, em que o aluno, o professor e o texto são participantes da interação é fundamental, para esta pesquisa, o contexto no qual os textos são produzidos, afinal, acredito que o ensino de gêneros e a produção escrita podem ser considerados construção de conhecimento.

Tal construção é fruto de vivências, experiências, elementos biográficos, trocas do falante/escritor com o mundo e da relação dialógica que se estabelece com o contexto. Neste aspecto, o texto é um mediador do mundo do aluno para o mundo externo.

A teoria de linguagem proposta pela LSF dá origem à Gramática Sistêmico-Funcional de Halliday (1994), que deve ser compreendida pelo viés semântico e funcional, considerando-se a rede de sistemas que constituem uma língua e a forma como os textos, ‘a linguagem que é funcional' (Halliday e Hasan, 1989, p.10) e as instâncias reais da língua se relacionam com o sistema linguístico.

O significado, a função e o sentido que o falante pretende expressar alicerçam os estudos na LSF, ou seja, é fundamental reconhecer as estratégias paradigmáticas nas escolhas linguísticas do falante, pois estão associadas à intenção comunicativa. Ao contrário da Gramática Formal, que parte da estrutura, nem sempre relacionada ao texto, afastada de seu significado, a Gramática Sistêmico-Funcional preocupa-se com o uso e com a estrutura no texto. Conforme Halliday (1994, p. xvii):

(...) uma análise do discurso que não é baseada na gramática não é uma análise, é apenas um comentário sobre o texto: ou se baseia em convenções não linguísticas ou em traços linguísticos muito triviais, que são acessíveis mesmo sem estarem baseados em uma gramática, como por exemplo, o numero de palavras por sentença. (Halliday, 1994, p. xvii)

O caráter contextual da Gramática Sistêmico-Funcional é ressaltado pelas escolhas que fazemos no uso da língua. Tais escolhas são dialógicas e também ideológicas em função de nossas relações sociais, dos papeis sociais que 
desempenhamos dentro de contextos específicos e da relação que estabelecemos com outros indivíduos, nossa biografia, crenças e valores.

Assim, é importante reconhecer o papel que a lexicogramática tem no processo de “reconhecimento" de intenções comunicativas por trás do texto, objeto considerado ponto de partida da análise na Gramática Sistêmico-Funcional. Através do lexicogramatical será possível observar, pontualmente, elementos funcionais próprios da linguagem que emergem dos textos, trabalhados dentro de habilidades e estratégias comunicativas específicas dos contextos de situação e cultura dos quais os falantes fazem parte.

Carregados de significados, o léxico e o gramatical compõem a gramática que Halliday (1994) propôs e que contempla os aspectos semântico, contextual e funcional da linguagem. Para compreender os três tipos de significados realizados pela linguagem há a divisão em três metafunções que decorrem de contextos interacionais.

A relação entre as variáveis do contexto e os três significados (ideacional, interpessoal e textual) dialogam e dão origem a três metafunções da linguagem: ideacional, interpessoal e textual. Tais significados fundamentam os usos da linguagem, já que o sujeito utiliza o significado ideacional para entender o mundo (interno e externo) que o cerca, o significado interpessoal para lidar com suas relações com os outros e o significado textual para realizar os demais significados. Segundo Moura Neves, esses componentes são:

(...) manifestações, no sistema linguístico, dos dois propósitos mais gerais que fundamentam todos os usos da linguagem: entender o ambiente (ideacional) e influir sobre os outros (interpessoal). Associado a esses, o terceiro componente metafuncional, o "textual”, lhes confere relevância. Desse modo, cada elemento, numa língua, é explicado por referência à sua função no sistema linguístico total. (Moura Neves, 1997, p.62)

Abaixo, vemos mais claramente a enunciação das Metafunções e a maneira como são realizadas, de acordo com seus sistemas, no texto: 


\begin{tabular}{|c|c|}
\hline METAFUNÇÃO & SISTEMA \\
\hline Ideacional & Relaciona-se ao Sistema da Transitividade. \\
\hline Interpessoal & Relaciona-se ao Sistema de Modo e Modalidade. \\
\hline Textual & Relaciona-se ao Tema e Rema. \\
\hline
\end{tabular}

Figura 3 - Metafunções e seus respectivos sistemas de significados

A Metafunção Ideacional refere-se à manifestação do conhecimento de mundo, nossas ideias e experiências no texto e pode ser dividida em dois componentes: o experiencial, que trata do conteúdo interno e estrutural de uma oração; e o componente lógico, que trata da organização dos grupos nominais e verbais, além da coesão textual.

Quando tratamos do componente ideacional da Metafunção, atuamos com o Sistema da Transitividade, que tem como núcleo o processo (realizado por um verbo) e pode contar com participantes e circunstâncias neste processo.

A Metafunção Interpessoal retrata as intenções e relações dos falantes/escritores, a interação entre participantes de um contexto e aspectos como questões de poder e/ou solidariedade estabelecidos no texto, distanciamento e/ou aproximação e a assertividade na mensagem. Na GSF, tais significados podem ser materializados em função de escolhas nos sistemas de Modo e Modalidade.

A Metafunção Textual manifesta as decisões do falante/escritor com relação aos componentes de uma informação na construção da mensagem. Tais decisões são demonstradas através dos elementos Tema e Rema que refletem escolhas dos falantes/escritores na organização das orações e seus sentidos no texto.

As metafunções se realizam no plano da expressão no texto que pode ser considerado, segundo a abordagem da LSF com a qual esta pesquisa se alinha, um potencial de escolhas e significados que serão fruto da linguagem no contexto. A abordagem LSF permite uma lente de investigação pela qual o texto e o contexto são fundamentais no processo de pesquisa e não podem ser dissociados. Pretendo, dessa maneira, observar as relações entre os participantes da pesquisa, como são estabelecidos seus posicionamentos e avaliações, com foco na metafunção interpessoal. Para tal, utilizarei a abordagem de linguagem da LSF em interface com o Sistema da Avaliatividade, que será explicado na próxima seção. 


\section{2}

\section{Sistema da Avaliatividade}

Inserido na Metafunção Interpessoal, cujo papel é permitir ao indivíduo posicionar-se com relação aos seus valores e experiências em uma situação comunicativa, o Sistema da Avaliatividade ${ }^{5}$ (Martin, 2000; White, 2004) oferece uma proposta de análise textual capaz de identificar a maneira como indivíduos adotam posicionamentos e valores diante de diversas questões e negociam significados, "um recurso semântico usado para negociar emoções, Julgamentos e apreciações” (Martin, 2000, p.145).

A partir da concepção Sistêmico-Funcional de linguagem, que abarca as escolhas paradigmáticas do falante, é possível identificar, em um nível semânticodiscursivo, a maneira como os indivíduos selecionam em seu repertório linguístico formas e estruturas que irão valorar e identificar seu posicionamento ideológico e seus julgamentos nos textos. Tal sistema linguístico foi denominado Avaliatividade por Martin (2000), e relaciona-se com os sentidos que negociam emoções, julgamentos e apreciações e são possíveis de serem identificados através de recursos linguísticos no campo semântico e lexicogramatical. Quando fazemos escolhas de estruturas linguísticas que apoiarão nossa construção ideológica, selecionamos e organizamos itens lexicais e gramaticais de maneira que criem determinados significados que desejamos produzir. Essas seleções que fazemos podem indicar, por exemplo, o posicionamento de um autor em um determinado texto.

Se um determinado falante em um debate (por exemplo, um candidato à prefeitura de uma cidade) decidir defender o corte de verbas para a merenda em escolas públicas, poderá escolher se posicionar de maneira mais acintosa dizendo: "temos que reduzir drasticamente a verba destinada à alimentação" ou poderá se posicionar de maneira mais conservadora: "temos que conter, um pouco, a verba destinada à alimentação”. Cada uma destas escolhas sugere uma determinada interpretação e indica um posicionamento por parte do falante (mais acintoso,

\footnotetext{
${ }^{5}$ De acordo com os fundamentos do Sistema da Avaliatividade, todas as categorias que se referem aos recursos da Avaliatividade são traçadas com a primeira letra maiúscula. Mantenho esta posição para identificar os recursos, Sistema e Subsistemas da Avaliatividade nesta pesquisa.
} 
mais conservador). Este exemplo indica o uso da Gradação, um dos recursos da Avaliatividade, que veremos mais detalhadamente na seção 2.2.3.

O Sistema da Avaliatividade (Martin e White, 2005) apresenta três Subsistemas: Atitude, Engajamento e Gradação, conforme a ilustração da Figura 4, a seguir. O Subsistema da Atitude trata dos sentimentos e reações emocionais que refletem nossos julgamentos e comportamentos diante de coisas, subdividindo-se em recursos de Afeto, Julgamento e Apreciação. O Engajamento preocupa-se com a interação de vozes no discurso e com o posicionamento do falante. Já o Subsistema da Gradação considera os aspectos de intensidade (maior ou menor) que utilizamos em nossos discursos para valorar nossos sentimentos e posicionamentos.

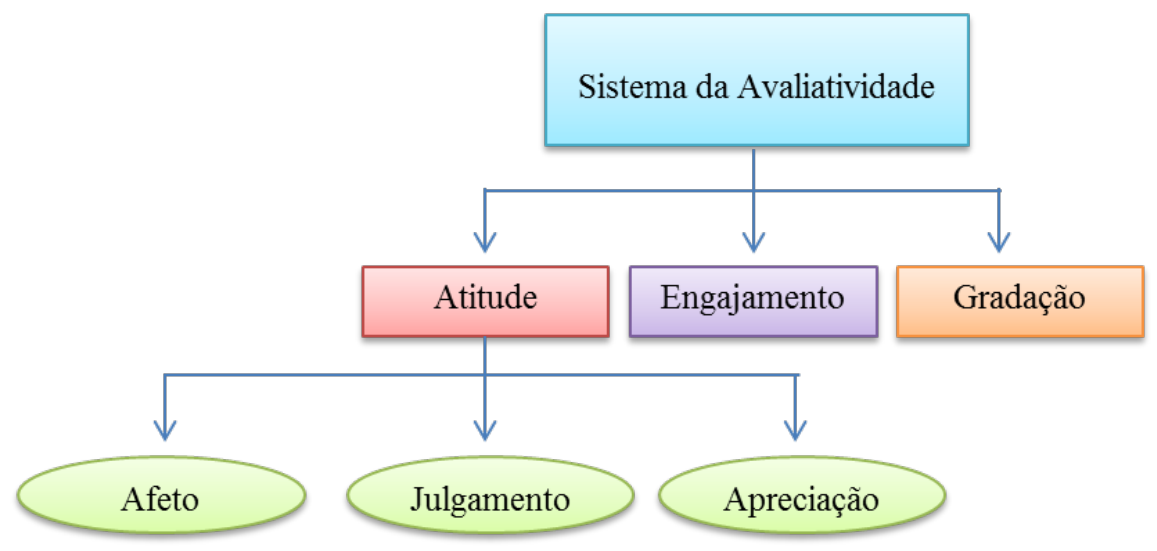

Figura 4 - Sistema da Avaliatividade

Como o alvo da investigação deste trabalho está na maneira como os alunos constroem seus posicionamentos nos textos através de avaliações relacionadas à atitude dos falantes acerca do tema proposto na redação elaborada com o grupo de alunos participantes desta pesquisa, os Subsistemas da Atitude, do Engajamento e da Gradação servirão de referência central para a análise dos textos investigados neste estudo. Porém, os elementos do Afeto, que compõem do Subsistema da Atitude, ainda que comentados, não serão o alvo desta análise. 


\subsection{1}

\section{Atitude}

O Subsistema da Atitude apresenta significados positivos e negativos, diretos ou implícitos, que envolvem emoções, caracterizadas através de avaliações de Afeto, como alegria/tristeza, amor/ódio, segurança/insegurança, satisfação/insatisfação; avaliações da estima e da sanção social, da ética e da moralidade compreendidos pelo Julgamento e, por fim, envolvem os sentimentos institucionalizados como a estética e o valor outorgado em critérios, relacionados à Apreciação. Todos os recursos da Atitude (Afeto, Julgamento e Apreciação) podem ser realizados de maneira direta ou implícita, positiva ou negativa.

O Afeto (emoções) está relacionado a emoções e pode ser considerado de maneira positiva ou negativa, direta - quando o sentido é expresso no texto - ou implícita - quando só localizamos a avaliação através da interpretação do texto. Pode ser autoral (presença objetiva do autor no texto e maior cumplicidade com o leitor) ou não autoral (presença subjetiva do autor no texto, não assumindo responsabilidade direta) dependendo da maneira como se posiciona o indivíduo produtor do texto.

O Afeto, conforme demonstrado na Figura 5, abaixo, é realizado lexicogramaticalmente pelo uso de substantivos (alegria, ódio, felicidade, etc.), de advérbios (geralmente de modo: felizmente, lamentavelmente, etc.), de adjetivos (feliz, satisfeito, triste, etc.) e de verbos (amar, adorar, desejar, etc.).

\begin{tabular}{|l|l|l|}
\hline \multirow{2}{*}{ AFETO } & Positivo/Negativo & $\begin{array}{l}\text { Felicidade, infelicidade; } \\
\text { segurança, insegurança; } \\
\text { satisfação, insatisfação. }\end{array}$ \\
\cline { 2 - 3 } & Direto/ Implícito & \\
\hline
\end{tabular}

Figura 5 - Resumo de Categorias de Afeto

O Julgamento (ética) relaciona-se a avaliações morais e comportamentais e pode ser subdividido em estima social (admiração ou crítica, sem implicações legais) ou sanção social (aprovação ou desaprovação, com implicações legais). Os critérios do Julgamento estão correlacionados ao Sistema de Modalidade da Gramática Sistêmico-Funcional, conforme Martin e White (2005), e podem ser 
realizados por advérbios, atributos e epítetos ligados ao substantivo, nomes e processos.

A Figura 6, a seguir, foi adaptada do trabalho de Martin e White (2005, p. 52 a 54) e elaborada na intenção de apontar a relação entre a modalidade e o Julgamento ${ }^{6}$.

\begin{tabular}{|c|l|l|l|l|}
\hline \multirow{2}{*}{ LSF: Modalidade } & Categoria & Forma Lexical & Significado & $\begin{array}{l}\text { Subsistema da } \\
\text { Avaliatividade: } \\
\text { Julgamento }\end{array}$ \\
\hline \multirow{2}{*}{ MODALIZAÇÃO } & Probabilidade & Provavelmente & É verdade? & $\begin{array}{l}\text { Sanção Social - } \\
\text { Veracidade }\end{array}$ \\
\cline { 2 - 6 } & Habitualidade & Geralmente & É normal? & $\begin{array}{l}\text { Estima Social - } \\
\text { Normalidade }\end{array}$ \\
\hline \multirow{2}{*}{ MODULAÇÃO } & Obrigação & Deve & É correto? & $\begin{array}{l}\text { Sanção Social - } \\
\text { Propriedade }\end{array}$ \\
\cline { 2 - 5 } & $\begin{array}{l}\text { Disposição - } \\
\text { Inclinação }\end{array}$ & Disposto a & $\begin{array}{l}\text { É de } \\
\text { confiança? }\end{array}$ & $\begin{array}{l}\text { Estima Social - } \\
\text { Tenacidade }\end{array}$ \\
\cline { 2 - 5 } & $\begin{array}{l}\text { Disposiçapaz de } \\
\text { Habilidade }\end{array}$ & É capaz? & $\begin{array}{l}\text { Estima Social - } \\
\text { Capacidade }\end{array}$ \\
\hline
\end{tabular}

Figura 6 - Resumo de Categorias de Julgamento correlatas à Modalidade

É importante ressaltar que o Julgamento também pode ser graduado (maior ou menor força). A figura 7, a seguir, indica os recursos de Julgamento, em suas categorias de estima e sanção social:

\begin{tabular}{|c|c|c|c|}
\hline & \multirow{3}{*}{ Estima Social } & Normalidade & É especial? \\
\hline JULGAMENTO & & Capacidade & É capaz? \\
\hline \multirow{3}{*}{$\begin{array}{l}\text { Positivo/Negativo } \\
\text { Direto/Implícito }\end{array}$} & & Tenacidade & É de confiança? \\
\hline & \multirow{2}{*}{ Sanção Social } & Veracidade & É honesto? \\
\hline & & Propriedade & É justo? \\
\hline
\end{tabular}

Figura 7 - Resumo de Categorias de Julgamento

\footnotetext{
${ }^{6}$ Apresento a correlação entre o Sistema da Avaliatividade (recursos de Julgamento) e a LSF (Sistema da Modalidade). Entretanto, é importante ressaltar que as categorias da Modalidade não serão, primordialmente, alvo deste trabalho e, portanto, não serão mais bem desenvolvidas aqui. Para outras consultas, ver Martin e White (2005).
} 
A Apreciação (estética) diz respeito à maneira como os indivíduos se posicionam em relação a objetos, performances e fenômenos naturais utilizando as mesmas possibilidades lexicais do Julgamento para sua realização. Enquanto a Apreciação atua no sentido de analisar ao desempenho sob o ponto de vista estético, o Julgamento tende a avaliar o comportamento sob o ponto de vista da ética.

Alguns elementos lexicais podem ser vistos como performáticos ou comportamentais, isto é, podem ser compreendidos como diferentes elementos da Avaliatividade. Em algumas situações, avaliadas como reações estéticas relacionadas à performance, compreendemos tais elementos como Apreciação, quando nos deparamos com aspectos comportamentais que desvelam reações éticas, consideramos que há Julgamento.

É importante considerar que entre o Julgamento e a Apreciação existem áreas nebulosas e, em alguns casos, as sobreposições entre elas são muito tênues, eventualmente os elementos do Julgamento e da Apreciação podem ser, de certa forma, sobrepostos e pertencer a dois Subsistemas simultaneamente (Nóbrega, 2009, p. 100). Na seção de análise desta pesquisa, há alguns exemplos que ilustram esta sobreposição, em que um item lexical poderia ser considerado um recurso da Apreciação ou do Julgamento.

No exemplo seguinte (também presente no capítulo de análise desta pesquisa), veremos que um item lexical poderia ser considerado um recurso da Apreciação, mas optei por considerá-lo como sendo um recurso do Julgamento em função de elementos semânticos contextuais que indicam um posicionamento por parte do autor mais próximo ao Julgamento do que da Apreciação. Vejamos a seguir:

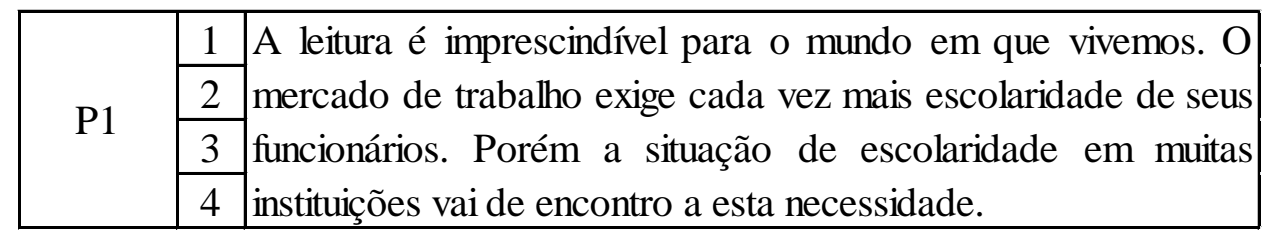

Redação 2 - Turma A1 - A importância da leitura e seus reflexos (cf. Anexo 2, p. 126)

Na Redação 2, notamos que o autor pretende indicar a importância da leitura. Entendo a leitura, aqui, como uma questão ética, que compreende sua 
importância na sociedade. Percebo que o autor não pretende apreciar positivamente a leitura considerando-a esteticamente como um artefato, mas sim julgar a habilidade de uma prática, realizada por pessoas, como imprescindível no contexto social em que vivemos. Confirmamos esta percepção quando, adiante, o autor explica que a situação de escolaridade em muitas instituições vai de encontro a esta necessidade (linhas 3 e 4), fazendo uso do Julgamento de estima social.

Em situações como esta há pistas lexicais e/ou elementos contextuais que podem se apresentar no texto e que permitirão que a análise seja feita por um determinado viés.

Por fim, a Apreciação aponta três tipos de conceitos: reação (quando o objeto contenta ou desagrada); composição (quando há equilíbrio/desequilíbrio e simplicidade/complexidade no que está sendo avaliado) e valor (a qualidade e o quão apreciado, ou não, pode ser determinado elemento), de acordo com o exposto na Figura 8:

\begin{tabular}{|c|l|l|l|}
\hline \multirow{2}{*}{$\begin{array}{c}\text { APRECIAÇÃo } \\
\text { Positivo/Negativo } \\
\text { Direto/Implícito }\end{array}$} & \multirow{2}{*}{ Reação } & Impacto & Me toca? \\
\cline { 3 - 4 } & \multirow{2}{*}{ Composição } & Qualidade & É satisfatório? \\
\cline { 2 - 4 } & & Equilíbrio & Está coeso? \\
\cline { 2 - 4 } & Valor & É difícil? \\
\hline
\end{tabular}

Figura 8 - Resumo de Categorias de Apreciação

Todos esses Subsistemas são realizados por elementos lexicogramaticais (atributos, processos e grupos nominais) que podem revelar o potencial argumentativo dos alunos nos textos, principalmente aspectos de posicionamento de valor autoral ou não-autoral de Afeto. Conforme White:

Ao avaliar os eventos em termos de Afeto, o falante/autor convida a sua audiência a compartilhar uma reação emocional, ou, ao menos, a entender a resposta como apropriada e motivada, ou, ao menos, compreensível. Quando esse convite é aceito, a solidariedade ou empatia entre falante e ouvinte será reforçada. Se essa relação de empatia for estabelecida, então há a possibilidade de o ouvinte estar mais aberto aos aspectos mais amplos da posição ideológica do falante. (White, 2004) ${ }^{7} 8$

\footnotetext{
${ }^{7}$ As traduções apresentadas neste trabalho foram realizadas por mim de forma livre.
} 
Quando o indivíduo assume um vínculo de cumplicidade com seu interlocutor no texto e responsabiliza-se por seu posicionamento, dizemos que está assumindo um posicionamento autoral. O contrário acontece quando ele não assume a responsabilidade tão evidentemente sobre o que argumenta e, algumas vezes, utiliza-se de outras vozes, fontes externas, para fazê-lo ou utiliza a impessoalidade causando um maior afastamento e menor cumplicidade com o leitor.

O Subsistema da Atitude auxiliará a análise dos dados desta pesquisa para que possamos, através de seus elementos, observar a maneira como o aluno atua no texto oferecendo maior ou menor grau de posicionamento.

A seguir, o Subsistema de Engajamento lidará com construtos da alteridade nos textos e a relação de vozes que se apresentam, de maneira a construir, também, o posicionamento do aluno.

\subsection{2}

\section{Engajamento}

Como vimos, o Sistema da Avaliatividade compreende recursos que estão se relacionam entre si (Atitude, Engajamento e Gradação, que veremos na seção 2.2.3, a seguir). O Subsistema do Engajamento está associado à interação entre vozes em um discurso, tendo estreita relação com a abordagem dialógica de linguagem proposta por Bakhtin (1992). Tal abordagem concentra-se na interação verbal e nos aspectos essencialmente dialógicos da linguagem.

Para Bakhtin (1992, p. 123) o discurso faz parte de uma discussão ideológica, “ele responde a alguma coisa, refuta, confirma, antecipa as respostas e objeções potenciais, procura apoio, etc.”, sendo que essas relações dialógicas operam nos mais diversos níveis, tanto no discurso escrito quanto na interação face a face. Para o autor, mesmo em produções monológicas há sempre uma relação dialógica e para se construir um discurso leva-se sempre em conta o

\footnotetext{
8 "By appraising events in such emotional/affectual terms, the speaker/writer invites her audience to share that emotional response, or at least to see that response as appropriate and well-motivated, or at least as understandable. When that invitation is accepted, the, solidarity or sympathy between speaker and listener will be enhanced. On such an empathetic connection has been established, then there is the possibility that the listener will be more open to the broader ideological aspects of the speaker's position."
} 
discurso de outras vozes. Um discurso é sempre constitutivo de outros discursos anteriores, ou seja, um enunciado carrega várias vozes que habitam o longo processo discursivo.

Podemos entender que o dialogismo é o princípio que constitui a linguagem e cada enunciado proferido é vinculado, em menor ou maior grau, por outros anteriores e será, também, vinculado aos demais que o sucederão. Conforme Bakhtin:

Cada enunciado é pleno de ecos e ressonâncias de outros enunciados com os quais está ligado pela identidade da esfera de comunicação discursiva. Cada enunciado deve ser visto antes de tudo como uma resposta aos enunciados precedentes de um determinado campo (aqui concebemos a palavra "resposta" no sentido mais amplo): ela os rejeita, confirma, completa, baseia-se neles, subentende-os como conhecidos, de certo modo os leva em conta. (Bakhtin, 2003, p. 297).

É importante ressaltar que a linguagem, de característica dialógica, constitui-se de vozes que podem emergir, no discurso, com maior ou menor intensidade e apresenta, por isso, maior ou menor envolvimento do autor com o texto. É no Engajamento que identificamos as digitais dos autores mais ou menos impressas e as sutilezas e insinuações de posicionamento e de que maneira estabelece-se a relação entre o autor e demais vozes no texto. Por isso, é possível, através das estratégias de Engajamento, negociar posicionamentos de forma mais ou menos explícita. Também dessa maneira, observamos o quão envolvido está o autor com as alegações que faz, de acordo com o grau de importância que dará a determinada voz em seu texto, a proximidade ou distanciamento que terá dessa voz.

De acordo com essa abordagem dialógica do texto, é possível depreender que nenhum enunciado será completamente novo, ele estará sempre vinculado a outras vozes. Dá-se, portanto, a natureza polifônica da linguagem e os entendimentos de como construímos nosso discurso em constante processo de negociação de pontos de vista. Podemos comparar a negociação de entendimentos no discurso com o processo argumentativo em um texto, que também apresenta, na origem, muitas vozes. E até mesmo considerar as respostas de enunciados anteriores, que são constituintes de outros discursos, como a contra argumentação, um movimento retórico característico do texto dissertativo-argumentativo. É 
importante considerar que, neste caso, para a abordagem Linguística SistêmicoFuncional, quaisquer escolhas linguísticas que o falante faça são, em primeira instância, escolhas intencionais do autor, ainda que possam parecer inconscientes.

Na Avaliatividade, é exatamente no Subsistema de Engajamento que são observados recursos que os falantes utilizam na negociação de valores atribuídos no discurso como mais ou menos responsivos, de acordo com o grau de comprometimento que o autor (falante/escritor) assume no texto. Os recursos de que o autor dispõe são a monoglossia - enunciado de voz única em que não se reconhecem aspectos dialógicos, a fonte do discurso é o próprio autor - e a heteroglossia - constituída por múltiplas vozes - que podem ser observados em todos os enunciados. Segundo a abordagem textual monológica e dialógica de Bakhtin:

(...) em todo enunciado, contanto que o examinemos com apuro, levando em conta as condições concretas da comunicação verbal, descobriremos as palavras do outro ocultas, ou semi-ocultas e com diferentes graus de alteridade. Dir-se-ia que um enunciado é sulcado pela ressonância longínqua e quase inaudível da alternância dos sujeitos falantes e pelos matizes dialógicos, pelas fronteiras extremamente tênues entre os enunciados e totalmente permeáveis à expressividade do autor. (Bakhtin, 1997, p.318)

Na monoglossia, como visto anteriormente, o enunciado está concentrado em uma única voz nítida - ainda que, segundo Bakhtin (2003), por mais monológico que seja um determinado enunciado, ele não deixa de ser uma resposta a enunciados anteriores, mesmo quando a expressão de uma voz externa não está nítida. Na proposta da Avaliatividade, há nos enunciados monoglóssicos duas formas de realizações, uma apresentação de Ponto pacífico e outra como Ponto questionável (Martin e White, 2005). O ponto pacífico parte de uma alegação que é aceita como verdadeira, válida e certa. O ponto questionável compreende um espaço duvidoso, controverso ou discutível, mas não necessariamente falso.

Em textos do tipo dissertativo-argumentativo podemos ter alegações que partem do "senso comum”, sendo que tais alegações podem ser consideradas de Ponto pacífico e segundo as orientações comuns que os professores fazem aos seus alunos, em sala de aula, não são o tipo de estratégia geralmente recomendada para alunos de prática de produção textual para a redação de seus textos. Entretanto, como veremos na análise deste trabalho, quando aliamos outros 
recursos da Avaliatividade ao Engajamento por Ponto pacífico, o posicionamento do autor torna-se mais forte.

Já na heteroglossia, há a possibilidade de apoiar o discurso em múltiplos posicionamentos oriundos de outras vozes. De acordo com a relação que se deseja estabelecer com as outras vozes, o autor utilizará a estratégia adequada à sua intenção, podendo aproximar-se do enunciado de maneira a posicionar-se diretamente no texto, reconhecendo-o como válido, ou com a possibilidade de distanciar-se do mesmo, a fim de suavizar seu posicionamento no texto.

No Engajamento, o posicionamento dialógico pode ser observado de acordo com dois parâmetros: o da contração/expansão dialógica, abrindo ou fechando a possibilidade de negociação dos enunciados, e o da vocalização interna/externa ${ }^{9}$, que indicam as fontes a que se referem os enunciados. Neste trabalho, me aterei aos critérios de contração e expansão dialógica.

Quando o autor mantem uma atitude em expansão dialógica, propicia a negociação de sentidos em um enunciado e abre espaços para outras vozes, concordantes ou discordantes, de aceitação ou rejeição. Do contrário, quando o escritor opta por manter uma atitude de contração dialógica ele resume ou inibe vozes alternativas, evitando o espaço de negociação no texto e torna-o menos dialógico.

Tais recursos de Engajamento, selecionados dentre os elementos interpessoais do sistema linguístico que o autor dispõe, permitem que ele crie espaços de negociação de sentidos ou restrinja seu texto destas possibilidades, indicando seu comprometimento com os enunciados e as orientações discursivas com as quais haja o alinhamento ou contraposição.

A figura seguinte é uma adaptação de White (2004, p.200) que propõe uma tabela ilustrativa dividindo os recursos de Engajamento de acordo com o espaço dialógico que lhes é conferido no texto, ou seja, o espaço de interação entre a voz textual e demais vozes e posições alternativas.

\footnotetext{
${ }^{9}$ Para mais detalhes, ver Martin e White, 2005, p. 102.
} 


\begin{tabular}{|c|c|c|c|}
\hline \multicolumn{4}{|c|}{ CONTRACÃO E EXPANSÃO DIALÓGICA } \\
\hline \multicolumn{3}{|c|}{ EXPANSÃO DIALÓGICA } & EXEMPLOS \\
\hline Entretenimento & Entretenimento & parece que & $\begin{array}{l}\text { Parece que Matheus estudou o ano } \\
\text { inteiro para esta prova. }\end{array}$ \\
\hline \multirow{2}{*}{ Atribuição } & Distanciar & alegam & $\begin{array}{l}\text { Matheus alegou ter estudado } \\
\text { durante a madrugada. }\end{array}$ \\
\hline & Reconhecer & dizem, relatam & $\begin{array}{l}\text { De acordo com o boletim, Matheus } \\
\text { estudou o suficiente. }\end{array}$ \\
\hline \multicolumn{3}{|c|}{ CONTRAÇÃO DIALÓGICA } & EXEMPLOS \\
\hline \multirow[b]{2}{*}{ Refutação } & Negar & não, jamais & $\begin{array}{l}\text { Há matérias que são muito difíceis. } \\
\text { Não há nenhum mal em tirar zero em } \\
\text { cálculo. }\end{array}$ \\
\hline & Contrapor & mas, porém & $\begin{array}{l}\text { Estudou muito até que conseguiu } \\
\text { tirar boas notas. O que é } \\
\text { surpreendente é ficar reprovado em } \\
\text { Geometria. }\end{array}$ \\
\hline \multirow{3}{*}{ Ratificação } & Endosso & mostra, demonstra & $\begin{array}{l}\text { Matheus demonstrou ter estudado } \\
\text { bastante para a prova de cálculo. }\end{array}$ \\
\hline & Pronunciamento & a verdade é que & A verdade é que ele estudou muito. \\
\hline & Confirmação de Expectativa & é claro, naturalmente & $\begin{array}{l}\text { Matheus, naturalmente, quer que } \\
\text { vejamos seu esforço. }\end{array}$ \\
\hline
\end{tabular}

Figura 9 - Resumo dos recursos de Engajamento

Os recursos de expansão dialógica, conforme ilustra a Figura 9, podem ser divididos em Entretenimento e Atribuição (reconhecimento ou distanciamento). Os recursos de Entretenimento ancoram a proposição em uma posição subjetiva, considerando alternativas dialógicas. No caso da Atribuição, a proposição está centrada na subjetividade da voz externa e a voz textual é uma dentre muitas outras vozes supostas. O recurso de Atribuição por reconhecimento permite que o autor não expresse seu posicionamento de maneira explícita, mas sim por outra voz que é trazida ao texto. Já no recurso de Atribuição por distanciamento, o autor expressa claramente seu distanciamento da proposição.

Como visto anteriormente, os recursos de contração dialógica permitem que o autor restrinja o espaço destinado a outras vozes alternativas no texto e se dividem em Refutação (negação ou contraposição) e Ratificação (endosso, pronunciamento e confirmação de expectativa).

O recurso de Refutação por negação consiste no uso expresso da negativa, contrariando a expectativa do leitor e não abrindo espaço para negociação de alternativas dialógicas. O recurso de Refutação por contraposição também estão relacionadas a formulações negativas que representem uma proposição concorrente substituindo um enunciado que era esperado.

Na Ratificação por endosso, a voz textual se alinha com uma voz externa que é representada como correta, conhecedora do assunto ou convincente, e, ao 
indicar um alinhamento do autor, esses enunciados se distanciam de posições contrárias, ou seja, reduzem o espaço dialógico já que a voz do autor se opõe a contraposição de ideias. Na Figura 9, apresentada na página anterior, podemos observar o exemplo de endosso em "Matheus demonstrou ter estudado bastante para a prova de cálculo”. Ora, se Matheus demonstrou, há provas, portanto, não há questionamentos possíveis a respeito do tema.

A Ratificação pelo pronunciamento se relaciona à intensificação que o autor dá aos seus enunciados na intenção de fazer com que o leitor não ofereça resistência à suas proposições. Já a Ratificação pela confirmação de expectativa mostra o enunciado como parte do senso comum, ou seja, não há, no leitor, nenhum tipo de resistência ao posicionamento do autor, há solidariedade entre autor e leitor.

Segundo a abordagem da Avaliatividade, as opções de contração e expansão dialógica podem estar presentes de múltiplas maneiras em um texto e permitem que as vozes variem o grau de Engajamento que os autores desejam ter com as demais vozes e posições no texto. Esses recursos serão bastante significativos na análise de dados deste trabalho, tendo em vista que a maneira como o autor se alinha ou se afasta de outras vozes nos permite compreender que tipos de posicionamentos procura adotar.

O Subsistema da Gradação, que veremos a seguir, apresentará os subsídios utilizados pelos alunos para acentuar ou atenuar determinado posicionamento e mostra-se como uma estratégia para que possamos observar a realização lexicogramatical das escolhas que os alunos fazem para elaboração dos textos desta pesquisa.

\subsection{3}

\section{Gradação}

Todos os Subsistemas da Avaliatividade são permeados uns pelos outros e na Gradação há a possibilidade de potencializarmos ou atenuarmos os sentidos em um determinado enunciado. Há elementos que atribuem força e foco em um enunciado. A Gradação é subdividida entre força - intensidade (utilizada para 
qualidade e processos) e quantidade (para entidades) e foco - reforço ou suavização.

Quando tratamos de foco, há elementos que podem causar ambiguidade ou tornarem o enunciado mais ou menos evasivo, o reforço pode ser observado quando a carga avaliativa é intensificada, por exemplo, (a) "Visitar o Peru é viver uma verdadeira experiência”, não trata-se, apenas, de uma experiência, mas sim “verdadeira”, há um reforço avaliativo na expressão.

Já a suavização pode-se perceber no exemplo (b) "Estudo em uma mesa que é tipo uma escrivaninha", quer dizer que há uma avaliação suavizada no exemplo, através da expressão "tipo uma escrivaninha”.

$\mathrm{Na}$ Gradação, a força pode ser identificada com termos que buscam enfatizar determinado enunciado e se realiza em intensidade, quando se tratam de qualidades e processos e quantidade, quando se tratam de entidades. No exemplo, podemos identificar os recursos de intensidade e quantidade no mesmo enunciado, respectivamente grifados: (c) "Matheus ficou muito feliz com seu presente de aniversário, contudo, precisei esclarecer um pequeno detalhe: seu intercâmbio será de, apenas, três semanas”.

Na figura a seguir, podemos observar a maneira como a Gradação é realizada no texto e os termos em destaque:

\begin{tabular}{|l|l|l|}
\hline \multicolumn{2}{|c|}{ REALIZAÇÃO DA GRADAÇÃO } \\
\hline FOCO & REFORÇO & $\begin{array}{l}\text { Visitar o Peru é viver uma } \\
\text { verdadeira experiência }\end{array}$ \\
\hline FOCO & SUAVIZAÇÃO & $\begin{array}{l}\text { Estudo em uma mesa que é tipo } \\
\text { uma escrivaninha }\end{array}$ \\
\hline FORÇA & INTENSIDADE & $\begin{array}{l}\text { Matheus ficou muito feliz com } \\
\text { seu presente de aniversário, }\end{array}$ \\
\hline FORÇA & QUANTIDADE & $\begin{array}{l}\text { contudo, precisei esclarecer um } \\
\text { pequeno detalhe: } \\
\text { intercâmbio será de, apenas, três } \\
\text { semanas }\end{array}$ \\
\hline
\end{tabular}

Figura 10 - Categorias da Gradação 
Nesta pesquisa, investigaremos a maneira como os alunos utilizam os recursos de Atitude, Engajamento e Gradação na construção do potencial argumentativo com o objetivo de reforçar seus posicionamentos de maneira que seus textos tenham um movimento mais autoral. Para isso, será necessário reconhecer a importância do domínio dos gêneros discursivos nas práticas sociais e, principalmente, como mediador da interação social.

\section{3}

\section{Gêneros Discursivos e a Redação de Vestibular}

Observar os gêneros discursivos é, ao mesmo tempo, observar como se estabelecem as relações humanas. Para este trabalho, serão analisadas redações de alunos do Ensino Médio, que simulam as Redações de Vestibular, um gênero amplamente estudado por diversos pesquisadores (Pilar, 2002; Cardoso, 2000). Em tais estudos, é importante considerar a maneira como os alunos se posicionam nos textos, exemplares deste gênero.

Neste estudo, duas visões se complementarão para fundamentação da teoria de gêneros, a visão da Nova Retórica de Miller (1984), que considera o gênero como a ação social e ressalta a importância do contexto, e a visão teleológica de Martin (1992), que entende o gênero como um sistema estruturado em partes, com meios específicos e para fins específicos.

Os sujeitos se inscrevem nos textos e, com isso, podemos verificar um maior ou menor grau de autoria em seus posicionamentos, individualizados nos textos. Entretanto, segundo Bakhtin (1992), há certa estabilidade nos gêneros que nos permite identificar sua forma. Ou seja:

É de acordo com o nosso domínio dos gêneros que usamos com desembaraço, que descobrimos mais depressa e melhor nossa individualidade neles (...), que refletimos, com maior agilidade, a situação irreproduzível da comunicação verbal, que realizamos, com o máximo de perfeição, o intuito discursivo que livremente concebemos. (Bakhtin, 1992, p. 304)

Portanto, a estabilidade que há em certo gênero nos permite inscrevê-lo em determinada prática, e em determinado contexto, ainda que existam 
individualidades - as quais são identificadas nos elementos lexicogramaticais citados nos itens da subseção 2.2, que serão objeto de investigação desta análise.

De acordo com a visão de Miller (1994), as práticas e os aspectos sociais são fundamentais na configuração do gênero. Os textos desta pesquisa, por exemplo, são permeados pelo contexto em que foram produzidos e, de certa maneira, refletem os posicionamentos ideológicos que fazem parte do diálogo entre o aluno e o mundo que o cerca. Por isso, entenderemos os textos que emergem do gênero Redação do tipo Vestibular como respostas às situações sociais recorrentes e formas de ação social.

Não podemos deixar de observar que há nos textos um objetivo, uma função a ser atingida. Desse modo, conforme Martin (1992, p.503), há um caráter teleológico, “um sistema de razões com meios e fins” que emerge dos gêneros. A rede de relações que existem entre os vários tipos de textos é o que permite a diferenciação funcional dos gêneros, já que há motivações contextuais que apontam para essas diferenças.

Nesse aspecto, as teorias de Miller e Martin se aproximam ao que consideramos fundamental para a análise de gêneros: a maneira pela qual o aluno responde ao contexto e identifica as ações sociais como ferramentas de expressão do posicionamento ideológico.

Para Miller (1994), os gêneros são caracterizados como formas de ação social, como respostas produzidas para situações sociais recorrentes, ou forma de ação retórica tipificada (Miller, 1994, p.24), já que por meio dela que criamos o conhecimento necessário para reproduzir a estrutura, mediando o particular e o público, o indivíduo e a comunidade.

A abordagem da autora para o estudo de gêneros se alinha com este trabalho, pois a partir do olhar para a ação social estamos garantindo um espaço de relevância para o contexto de produção dos textos desta análise. O gênero, desta maneira, funciona como mediador das interações, compreendendo que, das mais profundas formas de mediar a relação entre o particular, o universo do aluno, com seus valores, princípios e posicionamentos ideológicos, e o público, emerge o posicionamento autoral que é objetivo central desta análise.

E, ampliando esta investigação ao nível teleológico proposto por Martin (1992), podemos definir e observar o gênero como um sistema estruturado em partes, com meios específicos e para fins específicos, a partir do contexto de 
cultura, como uma ferramenta de análise de gêneros para alcançar objetivos específicos.

Conforme Miller (1994, p.39), aprender um gênero “é compreender melhor as situações em que nos encontramos e o potencial para o fracasso ou sucesso de uma ação conjunta”. Gêneros estruturam, organizam e regulam as ações e interações sociais, são o espelho da vivência dos enunciadores e a materialização desta experiência. E o exame vestibular, como, por exemplo, o ENEM (EXAME NACIONAL DO ENSINO MEDIO) pode significar para muitos um momento potencial de análise do sucesso ou fracasso do candidato, sendo uma importante ferramenta de observação do posicionamento do aluno.

No caso das universidades públicas do Rio de Janeiro, cidade em que se situa esta pesquisa, seus exames de seleção e ingresso são planejados com o suporte das notas do Exame Nacional do Ensino Médio, que são disponibilizadas para que o candidato possa ingressar no curso que deseja. Por isso, a prova de redação do ENEM é uma modalidade de redação de vestibular que contempla os mesmos critérios prototípicos do gênero Redação de Vestibular, ou seja, conta com características definidas pelo gênero como, por exemplo, a necessidade que o texto apresente características específicas de cada tipo de texto, no caso, o dissertativo-argumentativo; elementos dos mais diferentes tipos de coesão; delimitações de introdução, desenvolvimento e conclusão; dentre tantas outras características necessárias.

Na prova de redação do ENEM, o candidato deve escrever em até trinta linhas, e utilizando a norma culta da língua portuguesa, um texto dissertativoargumentativo. A prova oferece textos motivadores que incentivem a discussão de determinada questão polêmica apresentada pela proposta de redação e espera que o candidato, reunindo dados dessa coletânea e conhecimentos obtidos em sua formação escolar, produza um texto sobre o tema proposto, expressando seu ponto de vista e sustentando-o coerentemente com argumentos.

Partindo desse princípio básico, os alunos devem preparar-se para oferecer um texto que contemple os elementos: coesão, coerência, adequação à norma culta, exposição de ideias e argumentos, atendimento ao tema proposto, progressão temática e precisão vocabular, critérios definidos como estruturadores de um texto adequado às características que são esperadas pelos avaliadores. Assim, os alunos do ensino médio, geralmente no último ano, são orientados a 
produzirem textos nesses moldes, a fim de prepararem-se para os exames vestibulares.

O gênero em questão tem sido um dos objetivos-fim das aulas de redação, principalmente na última série do ensino médio e deve ser compreendido como uma ferramenta de construção do posicionamento do aluno. Nesse aspecto, é fundamental que o professor ofereça possibilidades de construção de conhecimento, leituras e atividades que proponham a reflexão dos alunos.

Nesse cenário, em uma perspectiva da LSF, Halliday (1978) relaciona gênero a aspectos textuais que indicarão um modo discursivo, assim:

A estrutura genérica está fora do sistema linguístico; é a linguagem como a projeção de uma estrutura de alto nível semiótico. Não é simplesmente uma característica dos gêneros literários; existe uma estrutura genérica em todos os discursos, incluindo a conversa informal mais espontânea (...). O conceito de estrutura genérica pode ser interposto dentro do quadro geral do conceito de registro, a padronização semântica que é caracteristicamente associada com o "contexto da situação" de um texto (Halliday, 1978, p. 134-135). ${ }^{10}$

Tal perspectiva de gêneros, oriunda da Escola de Sidney, é relevante para esta análise por estabelecer como perspectiva teórica as práticas discursivas que constituem um grupo social em uma interação dialógica com mecanismos socialmente construídos e contextualmente determinados pela situação e cultura.

Se observarmos o gênero em uma perspectiva social e em uma estreita relação entre texto e contexto, considerando-se as estabilidades pertinentes à prática da Redação de Vestibular, seremos capazes de compreender que da relação entre a ação social e o contexto emergem posicionamentos ideológicos que são fruto do processo de produção do texto na construção da visão crítica dos alunos.

Tais princípios orientam a análise deste trabalho propondo-se a analisar como encontramos, interpretamos, reagimos e criamos certos textos de acordo com o sistema semiótico que temos a nossa disposição e ao contexto em que estamos inseridos.

Os alunos do Ensino Médio são levados a construir textos que atendam ao gênero Redação do tipo Vestibular, em simulações feitas em sala de aula. É partir

\footnotetext{
10 "The generic structure is outside the linguistic system; it is language as the projection of a higher-level semiotic structure. It is not simply a feature of literary genres; there is a generic structure in all discourse, including the most informal spontaneous conversation (...). The concept of generic structure can be brought within the general framework of the concept of register, the semantic patterning that is characteristically associated with the 'context of situation' of a text" (HALLIDAY, 1978, 134-135).
} 
dessa construção que a análise deste trabalho será desenvolvida. Consideraremos, aqui, o gênero Redação do tipo Vestibular como o gênero que dá origem às simulações praticadas em sala de aula, ou seja, o material de análise deste trabalho é um gênero que nasce do gênero Redação de Vestibular. Algumas são as características que diferem os gêneros em questão e que situam os textos que simulam a redação de vestibular em outro gênero:

\begin{tabular}{|c|c|}
\hline $\begin{array}{c}\text { Gênero Simulação do Exame de Redação } \\
\text { do Vestibular }\end{array}$ & Gênero Redação do Vestibular \\
\hline $\begin{array}{l}\text { Produção - o texto é feito como um exercício } \\
\text { para o exame vestibular. }\end{array}$ & $\begin{array}{l}\text { Produção - o texto é realizado como uma } \\
\text { prova. }\end{array}$ \\
\hline $\begin{array}{l}\text { O autor é aluno - é oferecido ao aluno o } \\
\text { "direito de errar" sem que isso signifique } \\
\text { perder a oportunidade de ingressar na } \\
\text { universidade. }\end{array}$ & $\begin{array}{l}\text { O autor é candidato - só tem "uma chance" de } \\
\text { mostrar à instituição para a qual presta o } \\
\text { vestibular toda sua competência discursivo- } \\
\text { argumentativa. }\end{array}$ \\
\hline $\begin{array}{l}\text { Professor/Facilitador - } \mathrm{O} \text { autor reconhece o } \\
\text { leitor pessoalmente - trata-se de um professor } \\
\text { que o acompanha durante as aulas, no } \\
\text { processo de construção dos textos que servem } \\
\text { como exercício para a prova do vestibular. }\end{array}$ & $\begin{array}{l}\text { Banca/Sancionadora - O autor não reconhece o } \\
\text { leitor pessoalmente - trata-se de um } \\
\text { participante institucionalizado (“a banca”), não } \\
\text { são reconhecidos valores ideológicos que } \\
\text { constituem o grupo. Logo, selecionar os } \\
\text { argumentos que melhor se alinhem com a } \\
\text { audiência é mais difícil. }\end{array}$ \\
\hline $\begin{array}{l}\text { Ambiente familiar - } \mathrm{O} \text { ambiente no qual o } \\
\text { aluno faz a prova é reconhecido (sala de aula), } \\
\text { os colegas de classe são os mesmos, há certa } \\
\text { informalidade, pode haver a chance de refazer } \\
\text { o texto, sendo esses os elementos que } \\
\text { permitem que o autor esteja mais } \\
\text { descontraído. }\end{array}$ & $\begin{array}{l}\text { Ambiente Inexplorado - O ambiente é novo e } \\
\text { os candidatos concorrentes podem ser } \\
\text { elementos que acentuam a tensão do autor no } \\
\text { momento da prova, há formalidades e } \\
\text { orientações precisas para a prova, que devem } \\
\text { ser seguidas à risca pelos candidatos. }\end{array}$ \\
\hline
\end{tabular}

Figura 11 - Diferenças contextuais do gênero

Segundo Pilar (2002), as funções que a linguagem desempenha em um determinado contexto buscam explicitar o campo semântico do tema proposto, indicar os papéis sociais e as relações estabelecidas entre os participantes envolvidos no evento comunicativo e apontar o papel desempenhado pela linguagem no contexto comunicativo. Os elementos apresentados na Figura 11, acima, ilustram o contexto em que o aluno está imerso na prática do gênero.

Com o objetivo de ilustrar as delimitações e instruções oferecidas aos alunos e corretores para a confecção e correção da redação do ENEM, no anexo 
deste trabalho, disponibilizo uma matriz de competências para a redação do ENEM. Trata-se de uma grade de correção utilizada para este exame com a finalidade de orientar candidatos e corretores em todas as competências exigidas para um bom texto e os níveis de exigência de cada uma dessas competências.

A redação do vestibular é um gênero que tem a função de avaliar a habilidade de uso da linguagem do candidato aspirante à universidade. De acordo com Pilar:

(...) a redação de vestibular pode ser estudada como um aspecto da linguagem, uma forma de prática social, manifestação decorrente dos desejos ou necessidades que os indivíduos têm de conquistar novos espaços na sociedade (...), prática social que, se for relacionada à historia de vida do aluno, pode demonstrar a sua competência argumentativa enquanto sujeito, capaz de estabelecer a interação com seus interlocutores e de lutar, através da linguagem, para alcançar seus objetivos. (Pilar, 2002, p.171-172)

Logo, alcançar determinado propósito é ainda mais importante do que considerar o texto em si, simplesmente como um artefato linguístico. Por isso, torna-se fundamental ressaltar que os procedimentos utilizados para a construção dos textos analisados foram desenvolvidos, neste trabalho, com o propósito não apenas de qualificar os alunos para a Redação do Vestibular, como também promover a apropriação do gênero em questão na vida dos indivíduos envolvidos, a fim de que possam utilizar tal conhecimento em outros contextos comunicativos, para que seu uso não contemple apenas uma repetição de modelos textuais de outros autores.

Devemos considerar o contexto em que o aluno se encontra no momento da prova do ENEM ou de outro exame vestibular qualquer. Trata-se de um momento de avaliação, uma situação na qual o aluno é candidato à uma vaga em uma instituição e não produz um texto para alguém ler, mas para que sejam avaliadas as suas habilidades e competências de escrita. Uma prova de redação não é um evento real de comunicação, mas uma simulação obrigatória de condições de produção textual e possibilidades expressivas para alcançar um fim que não é a própria expressão em si, mas a aprovação, isto é, o sucesso que vem através de uma boa nota. 


\section{4}

\section{Argumentação}

Argumentum é um termo de origem latina cujo sentido “argu” é fazer brilhar. Assim, conforme Fiorin \& Savioli (1996, p. 284), argumento pode ser considerado "todo procedimento linguístico que visa persuadir".

O estudo dos processos argumentativos encontra suas origens na Grécia antiga com seu mais importante pensador, Aristóteles, inscrito no campo da Retórica; contudo, com a escola de Bruxelas (cf. Perelman, 1993; Perelman e Olbrechts-Tyteca, 1999), com a Semântica Argumentativa de Ducrot (1981) e com o Centro de Pesquisas Semiológicas de Neuchâtel (Grize, 1990) os estudos da Argumentação sofreram renovação.

A questão da argumentação relaciona-se com este trabalho na medida em que os textos que os alunos produziram para esta análise, e também aqueles comuns em exames como o ENEM, são do tipo dissertativo-argumentativo. É através do processo argumentativo que os alunos deverão demonstrar seu posicionamento nos textos e, segundo Breton:

Saber argumentar não é um luxo, mas uma necessidade. Não saber argumentar não seria, aliás, uma das grandes causas recorrentes da desigualdade cultural, que se sobrepõe às tradicionais desigualdades sociais e econômicas, reforçando-as? Não saber tomar a palavra para convencer não seria, no final das contes, uma das grandes causas da exclusão? Uma sociedade que não propõe a todos os seus membros os meios para serem cidadãos, isto é, para terem uma verdadeira competência ao tomar a palavra, seria verdadeiramente democrática? (Breton, 1999, p.19).

A argumentação se dá no texto e só é possível observá-la a partir deste ambiente, portanto, bem como a teoria de linguagem proposta pela LSF e utilizada neste trabalho, tal aspecto remete-nos ao texto e suas funções, aqui, a função argumentativa da linguagem.

Veremos que o processo da argumentação fundamenta-se na função do aspecto persuasivo que causa ao leitor. De acordo com Fiorin \& Savioli (1996), argumento é todo procedimento linguístico que tenha como fim a persuasão, ou seja, fazer com que o leitor aceite o que foi inferido no texto. Segundo Perelman \& Olbrechts-Tyteca (1999), de forma um pouco diferente, a argumentação é um processo que provoca no leitor uma escolha. 
Abreu (2003) propõe que o convencimento e a persuasão são características da argumentação e propõe que:

Argumentar é a arte de convencer e persuadir. Convencer é saber gerenciar informação, é falar à razão do outro, demonstrando, provando. [...] Persuadir é saber gerenciar a relação, é falar à emoção do outro. [...] Convencer é construir algo no campo das ideias. Quando convencemos alguém, esse alguém passa a pensar como nós. Persuadir é construir no terreno das emoções, é sensibilizar o outro para agir. Quando persuadimos alguém, esse alguém realiza algo que desejamos que ele realize.” (Abreu, 2003, p.25)

Para o autor, existem três condições para a argumentação. A primeira delas é a construção da tese e "saber para que tipo de problema essa tese é resposta" (2003, p.37). A segunda condição é ter uma linguagem comum com o contexto, ou seja, uma adaptação das nossas condições linguísticas com o leitor, a adequação das escolhas lexicogramaticais. Já a terceira condição da argumentação é ter um contato positivo com o interlocutor e, por fim, a quarta condição é agir de forma ética, honesta e transparente a fim de construir a credibilidade.

O autor explica que para obter sucesso na argumentação quando visamos o convencimento, aspecto importante para o texto dissertativo-argumentativo do gênero em questão, não devemos propor a tese principal logo no início do texto. Pelo contrário, devemos preparar a audiência com o uso da tese de adesão inicial, uma tese de fácil compreensão e concordância para que se possa conquistar estabilidade argumentativa, pois "é fácil partir dela para a tese principal. As teses de adesão inicial fundamentam-se em fatos ou em presunções [...], suposições fundamentadas dentro daquilo que é normal ou verossímil” (Abreu, 2003, p. 46).

As ideias de Abreu (2003) ainda propõem que quando começamos um processo argumentativo visando ao convencimento de um interlocutor, no caso desta pesquisa, um leitor, não devemos propor de imediato a tese principal. De outra maneira, devemos "preparar o terreno para essa tese principal, propondo alguma outra tese, com a qual o nosso auditório possa antes concordar” (2003, p.45), a tese de adesão inicial. Tal recurso, como veremos na seção dedicada à análise dos dados deste trabalho, é muito utilizado nos textos do tipo dissertativoargumentativo aqui investigados.

De acordo com Breton (1999, p. 64) “argumentar é mais do que simplesmente conceber um argumento. É também, mais globalmente, comunicar, 
dirigir-se ao outro, propor-lhe boas razões para ser convencido a partilhar de uma opinião”. Ou seja, a argumentação propõe um momento de partilhar valores, ideais e posicionamentos de acordo com os pontos de vista dos autores e pode ser, por essa razão, um método bastante promissor de verificar o movimento autoral dos alunos nos textos.

Três elementos centrais para compreendermos a atividade humana de finalidade argumentativa, de acordo com a proposta de Breton (1999). Para o autor, argumentar é (a) comunicar, o que implica a existência de um interlocutor e de uma mensagem - que, neste trabalho, considero como sendo a "tese”, ponto de vista do autor; (b) argumentar não é convencer a qualquer custo - pressupondo uma ruptura com os modelos da Retórica Clássica, que visava persuadir a qualquer preço; (c) argumentar é raciocinar, ou seja, propor um pensamento, ideologia e opinião ao interlocutor, fundamentando, com boas razões, seu ponto de vista.

O percurso argumentativo selecionado pelo aluno/autor pode variar de acordo com o tipo de argumento selecionado, especificamente. As estratégias que o autor utilizará em seu texto podem se matizar de acordo com o a estrutura argumentativa selecionada e de acordo com a escolha do tipo de argumento, o que Abreu (2003, p.49) chama de “Técnicas Argumentativas”.

A divisão dos argumentos nas categorias propostas por Abreu (2003) será utilizada neste trabalho por ser parte do conteúdo oferecido na disciplina de Produção Textual e do material didático que os alunos, produtores dos textos considerados simulações do gênero Redação do tipo Vestibular, utilizam no $3^{\circ}$ ano do Ensino Médio do colégio em que a pesquisa foi realizada.

Segundo Abreu (2003), os tipos de argumento dividem-se em argumentos quase lógicos - relacionados à objetividade dos fatos, e argumentos fundamentados na estrutura do real - relacionados a pontos de vista e opiniões relativas a eles. A seguir, veremos algumas explicações sobre cada um dos argumentos categorizados nas duas divisões argumentativas. 
I) Argumentos Quase Lógicos:

a) De compatibilidade e incompatibilidade - demonstram que uma tese anterior (tese de adesão inicial) pode ser congruente ou contrária à tese principal.

b) De regra de justiça - fundamentam-se no tratamento idêntico a seres da mesma categoria, apoiam-se em precedentes, ou seja, espera-se uma equivalência na conduta diante de questões que possuem referências ou similaridades entre si.

c) De retorsão - constroem-se na réplica, contestação ou contradição dos argumentos do interlocutor (costumam, por isso, utilizar-se de vozes intertextuais).

d) Do ridículo - fundamenta-se em criar uma situação irônica ou sarcástica ao se empregar, de forma temporária, um argumento oposto, extraindo dele todas as conclusões por mais esdrúxulas que sejam.

e) De definição - justificam-se através de lógica, de pontos de vista, da expressividade, da normalidade e da etimologia para explicitar o sentido que se quer dar a um enunciado. Os argumentos de definição são muito utilizados em teses de adesão inicial.

II) Argumentos Fundamentados Na Estrutura do Real:

a) Argumento pragmático - fundamenta-se na relação de dois acontecimentos sucessivos, consecutivos, por meio de uma relação de causa, usando a transferência de valor de uma consequência para sua causa. Ou seja, para que um argumento pragmático seja válido é preciso que o leitor admita o valor de uma inferência.

b) Argumento do desperdício - consiste na afirmativa de que é preciso completar um trabalho, uma vez que se tenha dado início a ele.

c) Argumentação pelo exemplo, modelo ou antimodelo - apoia-se nos feitos e ações de outras pessoas levando-as como exemplos a serem seguidos ou evitados, de acordo com a construção argumentativa que se vá escolher. Para corroborar com uma tese é preciso deixar claro o modelo ou exemplo que deva ser seguido ou, do contrário, evitado (antimodelo). 
d) Argumentação pela analogia - esta técnica utiliza-se de um fato que tenha relação analógica com a tese principal, comparando elementos ou declarações que, muitas vezes por si só, são capazes de representar a ponderação que se deseja julgar como correta/incorreta, justa/injusta ou conveniente/inconveniente.

O estudo da Argumentação oferece a este trabalho subsídios para que possamos observar o posicionamento autoral do aluno, expresso no texto, por meio de argumentos. E se alinha com esta investigação, tendo em vista que as representações e crenças partilhadas entre alunos e banca, autores e leitores, podem estar inscritas nos posicionamentos dos autores.

É importante observar que quando pensamos no percurso argumentativo presumimos o ato de convencer ou persuadir o outro a concordar com o que julgamos como válido, mas é importante ter em consideração que a nossa sensibilidade também precisa estar ajustada aos valores do outro.

Tratando-se de uma pesquisa que (conforme veremos na seção dedicada à metodologia deste trabalho) envolve participantes, que embora não reconheçam teoricamente o Sistema da Avaliatividade, mencionado no item 2.2 desta seção, os alunos (autores dos textos analisados no capítulo 4, adiante) sabem fazer uso de recursos da linguagem, reconhecem as estratégias argumentativas de que dispõem e são instruídos a fazerem uso dos mais diferentes tipos de argumentos, portanto, são preparados para compreender quais valores (concretos ou abstratos, éticos, morais, sociais, culturais, etc.) estão em questão e são capazes de serem sensíveis a estes valores, sendo, portanto, aptos a persuadir/convencer.

O potencial argumentativo repousa na habilidade de construir, através de argumentos, um percurso previamente selecionado - de acordo com as estratégias que dispomos - para levar o outro a concordar com a tese que pretendemos defender. Há um potencial argumentativo que repousa nos valores que dispomos para as coisas, pessoas, situações e eventos.

Tais valores podem ser concretos (valores de joias, de automóveis, de imóveis) ou abstratos (o valor de uma música, de um beijo, da justiça, lealdade, amizade) e variam em função da multiplicidade de grupos que fazemos parte, de pessoa para pessoa, em função da cultura, da ideologia e da própria historia pessoal. Portanto, os mesmos valores não são impostos a todas as pessoas, mas 
sabemos que pontos e questões são mais ou menos viáveis ou importantes ao abordar um determinado assunto com alguém, ou escolher uma tese diante de uma situação comunicativa.

Como vimos neste capítulo, na seção 2.1, que trata da abordagem sociossemiótica de linguagem, a Linguística Sistêmico-Funcional possibilita compreender a linguagem como um recurso criador de sentidos (Eggins, 2004), já que é através dela que os indivíduos revelam seus valores. Da mesma maneira, considero, neste trabalho, a linguagem como um sistema de construção de significados (Halliday, 1994), isto é, há um sistema de escolhas paradigmáticas, intencionais ou não, que o sujeito faz em meio a múltiplas oportunidades que tem a sua disposição.

Como um instrumento de interação social e um processo de produção de sentidos que emergem de textos vivos, reais, a linguagem possui significados que são adquiridos no uso. Os contextos de produção e as escolhas paradigmáticas que envolvem a produção de sentidos nos permite compreender este 'potencial de significados’ (Martin e White, 2005, p. 24) que temos a nossa disposição.

Observando a relação que existe entre o "potencial de significados" e o “potencial argumentativo” é possível tecer um paralelo entre a abordagem de linguagem deste trabalho e o estudo da argumentação. Proponho que ambos possuem potencial de criação de posicionamentos, um sem número de possibilidades de escolhas que emergem de sistemas de representação que o autor pode dispor de forma consciente (como é o caso das estratégias de argumentação usadas pelos participantes desta pesquisa) ou inconsciente (como é o caso dos elementos da Avaliatividade de que os autores fazem uso, ainda que não os reconheçam teoricamente).

As palavras não são conceitos, rótulos, legendas ou selos que colocamos em coisas, objetos, pessoas, ideias, sentimentos e formas de agir, palavras são meios de representar tudo isso, são sistemas de representação. Quando usamos a linguagem, estamos fazendo uma escolha de como representar o que desejamos, criamos efeitos que são produzidos em função das nossas escolhas semânticas e lexicais.

Ao selecionarmos argumentos, estamos, da mesma forma, escolhendo como negociar com o outro o que desejamos, escolhemos como desejamos expor 
nosso posicionamento, de maneira que possamos explicitar nosso ponto de vista e fazer com que o leitor concorde com ele, ou, pelo menos, entenda-o.

Ambas, argumentativas ou de linguagem, são escolhas potenciais que acontecem em detrimento de outras. O caráter paradigmático da linguagem também se encontra na construção argumentativa de um texto, portanto, em ambos os casos há, em repouso, um potencial de criação de posicionamentos em que reside um potencial argumentativo e um potencial de significados.

Proponho que, nos textos do tipo dissertativo-argumentativo, a cada seleção que o autor faz relacionando o uso das estratégias argumentativas e o uso de recursos de linguagem, cria-se um novo potencial de posicionamentos. Veremos no capítulo destinado à análise dos textos desta pesquisa (capítulo 4) como se constroem tais posicionamentos.

Essa relação entre o potencial de significados e o potencial argumentativo é importante para realçar que os significados são realizados de tal maneira que qualquer modificação afetará todos os seus níveis. Ou seja, caso mudemos a abordagem argumentativa ou realização dos significados interpessoais, por exemplo, estaremos modificando os significados produzidos, criando um novo potencial de posicionamentos. Para ilustrar esta relação proponho a figura abaixo:

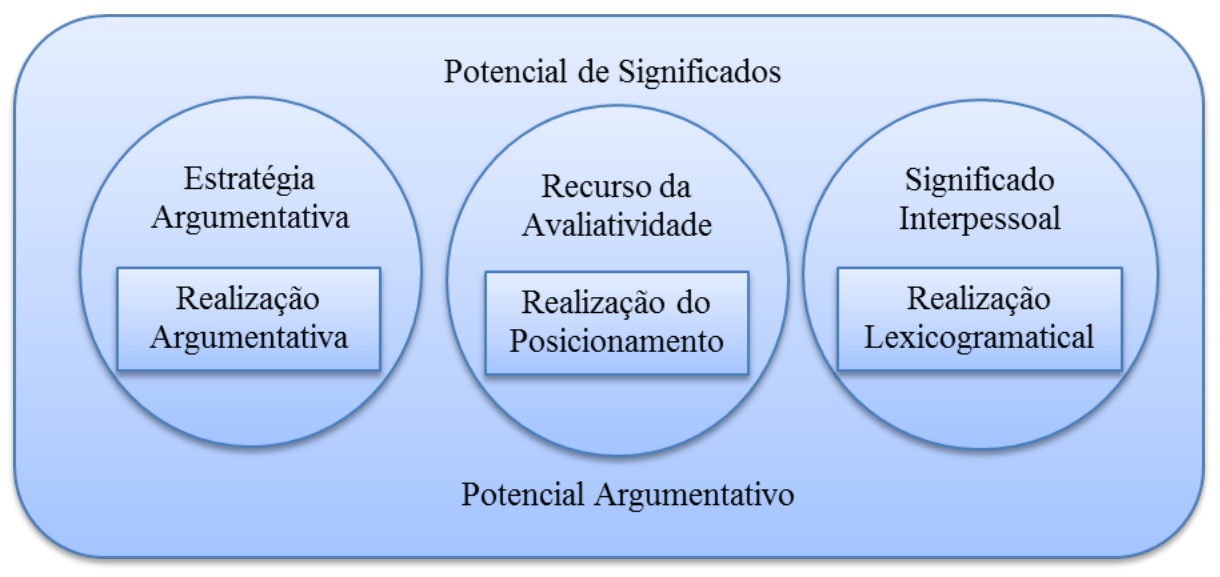

Figura 12 - Potencial de Posicionamentos

Como citado anteriormente na seção 2.1.2, que trata do contexto e das realizações da linguagem, há uma correlação entre a realização da linguagem e o contexto, estabelecendo uma associação entre as metafunções e as variáveis de registro. Proponho uma correlação que integre os tipos de significados que compreendem todo o potencial de significados ao potencial argumentativo. 
Qualquer modificação na seleção de uma estratégia argumentativa poderá significar em uma realização argumentativa diferente, qualquer modificação no uso de um recurso da Avaliatividade poderá significar em uma mudança na realização do posicionamento autoral, qualquer modificação nos significados interpessoais, pode significar uma modificação do potencial de significados.

No capítulo 3, a seguir, será apresentado o suporte teórico com o qual foi desenvolvida a metodologia deste trabalho, as condições de produção dos textos desta análise, o contexto e os participantes. Também serão apresentados os procedimentos de pesquisa e as categorias de análise. 


\title{
3
}

\section{Metodologia}

\begin{abstract}
O texto me escolheu, através de toda uma disposição de telas invisíveis, de chicanas seletivas: o vocabulário, as referências, a legibilidade, etc.; e, perdido no meio do texto (e não atrás dele ao modo de um deus de maquinaria) há sempre o outro, o autor.
\end{abstract}

Roland Barthes (2002, p.35)

Após discutir, no capítulo anterior, a fundamentação teórica que ancora este trabalho, passo à metodologia utilizada para a realização desta pesquisa para investigar a construção do posicionamento do autor nos textos dissertativoargumentativos. Dessa maneira, serão apresentados, nas seções seguintes, os pressupostos metodológicos que nortearam esta pesquisa; o contexto na qual foi desenvolvida; o tema da redação que deu origem aos dados analisados; os participantes da pesquisa e encerro com os procedimentos de pesquisa e as categorias de análise.

\section{1}

\section{Pressupostos metodológicos}

Os procedimentos metodológicos adotados neste trabalho estão alinhados à concepção teórica de linguagem apresentada no capítulo 2 e aos pressupostos da pesquisa interpretativa e qualitativa (Lincoln e Denzin, 2006), já que, como pesquisadora, fui também participante do processo de pesquisa, da geração de dados e do contexto em geral.

De acordo com Lincoln e Denzin (2006, p.391) “o pesquisador qualitativo não é um observador objetivo, oficial, politicamente neutro, que está fora ou acima do texto”, logo, minha participação na pesquisa contempla também meus valores e crenças. Esta é, portanto, uma pesquisa de cunho qualitativo que compreende que o envolvimento do pesquisador no processo é natural, pois não é um sujeito livre de crenças, valores e questões pessoais. O paradigma qualitativo propõe que o pesquisador não possui uma postura neutra, uma vez que seu envolvimento faz parte do processo de interpretação e descoberta. 
Não pretendo, com isso, que as descobertas desta pesquisa sejam interpretadas apenas por mim, ou sob as mesmas lentes, já que acredito que leituras e releituras possam levar esta pesquisa para outras fronteiras que contemplem novos olhares.

A pesquisa qualitativa voltada para a sala de aula contempla uma série de aspectos que envolvem a prática pedagógica, como a participação dos alunos, o envolvimento do professor, o conteúdo da aula e mesmo as rotinas escolares comuns ao dia a dia. Segundo Bortoni-Ricardo:

(...) o objetivo da pesquisa qualitativa em sala de aula (...) é o desvelamento do que está (...) no dia a dia dos ambientes escolares, identificando processos que, por serem rotineiros, tornam-se "invisíveis" para os atores que deles participam. (Bortoni-Ricardo, 2008, p. 49)

Entendo que como professora-pesquisadora, por fazer parte do processo, influencio e sou influenciada por esta pesquisa e que o contexto investigado contribui para o desenvolvimento desta pesquisa ao mesmo tempo em que o meu conhecimento e o dos alunos ia sendo construído.

Alguns aspectos da abordagem qualitativa são fundamentais para compreendermos a natureza em que se insere esta pesquisa. Para Bodgan e Biklen (1982 apud Lüdke e André, 2001, p.11) a pesquisa qualitativa implica (a) um ambiente natural como fonte direta dos dados e o pesquisador como seu principal instrumento; (b) a geração de dados predominantemente descritivos; (c) maior preocupação com o processo do que com o produto; (c) foco especial para o significado que as pessoas dão às coisas e à vida e (d) sequência indutiva de análise dos dados.

Por meio da abordagem qualitativa, desenvolvo uma análise documental (Appolinário, 2009; Cellard, 2008) que compreende o uso de documentos com fins de observar e extrair informações que nos possibilitem ampliar nossos entendimentos. Segundo Cellard (2008, p.295), “o documento escrito constitui uma fonte extremamente preciosa para todo pesquisador (...) e (...) muito frequentemente, ele permanece como o único testemunho de atividades particulares ocorridas num passado recente”.

É importante ressaltar que a análise documental indica que os documentos originais constituem uma inesgotável e preciosa fonte de informações que 
expressam informações factuais, favorecendo a observação de fatores, inclusive contextuais, no processo de maturação de indivíduos, sociedades, conceitos e grupos.

Para este trabalho, portanto, os documentos gerados através das redações dos alunos consistem em uma fonte de informações que podem ser interpretadas e observadas sob a luz de abordagens teóricas diversas - escolho, aqui, as abordagens que foram amplamente discutidas no capitulo destinado aos aspectos teóricos desta pesquisa. Também é importante realçar que tais documentos refletem um contexto específico da educação no Brasil, mais precisamente na cidade em que se desenvolve esta pesquisa e, em maior escala, para a instituição de ensino em que atuei juntamente com os demais participantes da pesquisa.

Julgo imprescindível comentar que, segundo Helder (2006, p. 1), “a técnica documental vale-se de documentos originais, que ainda não receberam tratamento analítico por nenhum autor.”, por esta razão as redações aparecem, neste trabalho, exatamente como foram escritas, respeitando-se, portanto, as incorreções gramaticais e demais questões que os autores produziram. A análise documental elimina, ao menos em parte, a eventualidade de qualquer influência, presença ou intervenção do pesquisador.

Segundo Appolinário (2009, p.27) este tal tipo de pesquisa é permeado por um conjunto de técnicas de investigação que são caracterizadas pela análise de dados linguísticos, assim, “os elementos fundamentais da comunicação são identificados, numerados e categorizados. Posteriormente as categorias encontradas são analisadas em face de uma teoria específica”. Exatamente dessa maneira foram estabelecidos os procedimentos de pesquisa deste trabalho, que veremos adiante.

Minha abordagem, neste estudo, não objetiva alcançar uma regra geral ou modelo ideal da prática ou da produção textual, pelo contrário, a abordagem qualitativa com a qual me alinho procura o entendimento das particularidades de cada ambiente pesquisado e meu desejo é investigar os aspectos que tornam o contexto desta pesquisa singular.

Conforme André (2009, p. 61), “(...) o pesquisador não pode deixar de lado os seus valores, as suas crenças e os seus princípios. No entanto, ele deve estar ciente deles e deve ser sensível a como eles afetam ou podem afetar os dados”, estou ciente de que como pesquisadora, e uma participante da pesquisa, 
meus valores e pontos de vista incidem e afetam a pesquisa, contudo, resguardo este espaço de entendimento para observações posteriores, no capítulo final deste trabalho.

Este trabalho não pretende ter nenhuma implicação política no que diz respeito às práticas educacionais em língua portuguesa ainda que, como professora, pretenda fazer uso dos entendimentos desta pesquisa para melhorar a minha prática docente sem a pretensão de uma aplicação deste trabalho como um modelo a ser seguido.

A seguir, explicarei detalhadamente o cenário em que se desenvolveu esta pesquisa, além dos participantes, tema da proposta de redação, procedimentos de pesquisa e categorias de análise.

\section{2}

\section{Contexto e corpus}

Esta pesquisa foi desenvolvida em uma escola pública, localizada na cidade do Rio de Janeiro, e considerada uma excelente instituição de ensino tradicional, na qual o acesso é oferecido de duas maneiras: concurso público para os alunos do $6^{\circ}$ ano do Ensino Fundamental e $1^{\circ}$ ano do Ensino Médio ou transferência interna.

Fui professora desta instituição durante todo o desenvolvimento desta pesquisa e reconheço que se trata de um contexto de ensino-aprendizagem que conta com as mais variadas ferramentas pedagógicas, tanto no que compete aos suportes tecnológicos, como na maneira como são conduzidas as aulas, os encontros entre professores, os cursos de atualização e os mais diferentes instrumentos de apoio ao professor.

Diante do contexto em que se desenvolveu este trabalho, considero importante destacar algumas características que retratam o ambiente no qual se desenvolveu esta pesquisa e a prática do ensino da Produção Textual no $3^{\circ}$ ano do Ensino Médio do colégio em questão:

(1) As aulas são exclusivamente de redação, com carga horária destinada apenas à produção textual, não sofrendo, com isso, nenhum tipo de interferência para que seja cumprida a carga temática de Língua Portuguesa do $3^{\circ}$ ano. 
(2) As turmas do $3^{\circ}$ ano do Ensino Médio são divididas de acordo com a área de interesse do aluno para qual prestará exame vestibular. Logo, os grupos são divididos por área de conhecimento. Assim, os alunos cursam uma carga horária maior destinada às matérias para as quais prestarão provas específicas nos vestibulares. A disciplina de redação/produção textual possui a mesma carga horária em todas as turmas, com dois tempos sequenciais de 50 minutos, totalizando uma hora e quarenta minutos por semana.

(3) Todas as turmas são divididas, aleatoriamente, em duas outras turmas, com uma média de 20 alunos cada, e são destinados professores de redação diferentes e salas de aula distintas para cada grupo, com o objetivo de oferecer uma forma de acompanhamento mais atenta e menos uniforme entre professor e aluno. Geralmente, uma turma com a média de 40 alunos é dividida em duas outras turmas de 20 alunos, cada qual contando com um professor de produção textual diferente que acompanha os alunos de maneira mais individualizada ${ }^{11}$.

(4) Durante o ano letivo, todos os textos escritos produzidos pelos alunos do $3^{0}$ ano do Ensino Médio são, fundamentalmente, do tipo dissertativoargumentativo. Todos os textos são corrigidos com base nas grades de correção ${ }^{12}$ dos concursos vestibulares, como, por exemplo, o Exame Nacional do Ensino Médio, e são devolvidas aos alunos, individualmente, com comentários sobre cada aspecto observado nos textos. Nas séries anteriores, os alunos têm contato com textos narrativos e descritivos.

(5) Há a existência de um trabalho sistematizado sobre o tipo de texto tratado nesta análise, os alunos recebem orientações claras, materiais didáticos específicos e diversos outros temas de redação do mesmo tipo textual para aplicarem seus conhecimentos.

(6) Geralmente os alunos debatem verbalmente sobre o tema e depois elaboram seus textos, exceto nas provas bimestrais. É importante ressaltar que

\footnotetext{
${ }^{11}$ Em algumas turmas, a divisão de alunos por grupo não é igual, isto é, uma professora fica com um grupo de alunos maior ou menor do que o grupo de alunos da outra professora. Isso acontece por determinação da direção da escola.

${ }^{12}$ Os concursos vestibulares para as universidades públicas do Rio de Janeiro contemplam critérios de correção padronizados que chamamos de grades de correção (cf. exemplo no anexo 20, p. 146). Tais critérios são trabalhados em sala de aula, com os alunos, com a intenção de prepará-los para a prova do vestibular.
} 
para a proposta de redação utilizada nesta análise os alunos não discutiram o tema, bem como não estavam cientes de que ele seria objeto de análise posterior.

(7) Conforme veremos na seção 3.3, a escolha do tema da redação ${ }^{13}$ para esta pesquisa foi feita objetivando o posicionamento explícito do aluno e o comando da proposta orientava o autor a oferecer um ponto de vista sobre o assunto.

(8) Os alunos não fazem uso de livro didático, mas de uma apostila de produção textual elaborada por mim, exclusivamente, para as turmas de $3^{\circ}$ ano. As apostilas são iguais para as todas as turmas.

(9) Os exames bimestrais da instituição são chamados internamente de "simulados”, pois imitam as provas vestibulares que os alunos serão submetidos para ingressarem nas instituições desejadas. Portanto, as redações não podem ser consideradas exemplares prototípicos do Gênero Redação de Vestibular, mas sim exercícios de simulação deste gênero. As redações utilizadas nesta análise foram produzidas nesse contexto, como simulados da prova de redação do vestibular.

(10) Os alunos têm ciência de que suas redações, mesmo aquelas que funcionam como exercícios, serão corrigidas pelo professor da disciplina. Assim, a relação de desconhecimento da "banca do vestibular" não pode ser reproduzida nos simulados do colégio.

(11) Os alunos participaram de debates orais durante o ano letivo no qual foi conduzida esta pesquisa antes de sua realização e com a intenção de trabalharem aspectos argumentativos, mas não discutimos, na escola, o tema da redação utilizado para esta pesquisa.

(12) A escola conta com salas de aula amplas, bem iluminadas, arejadas e há climatização apropriada. Os alunos sentam-se em carteiras organizadas tradicionalmente em fileiras, mas, nas aulas de redação frequentemente mudamos as posições das cadeiras para promover discussões e debates frente a frente. Há,

\footnotetext{
${ }^{13} \mathrm{O}$ tema da redação desta análise foi elaborado em conjunto por mim, pela professora orientadora desta dissertação e por outra pesquisadora, Adriana Rodrigues de Abreu (2003), que desenvolveu sua pesquisa com base no corpus do Projeto Escrita e inclusão social: análise da (re)construção identitária no Ensino Médio, coordenado pela Profa. Adriana Nogueira Accioly Nóbrega, orientadora deste trabalho, na PUC-Rio.
} 
nas salas de aula, murais destinados à produção textual em que os alunos podem, caso queiram, afixar seus textos.

(13) Os alunos têm acesso à biblioteca da escola e frequentemente fazem uso desse espaço para leitura e pesquisa.

(14) As aulas são, em grande maioria, veiculadas em recursos multimídia, como o "quadro interativo". Todas as salas possuem equipamentos como: computador, projetor, quadro branco e equipamento de som, além dos softwares e hardwares que compõem o quadro interativo.

Os dados desta análise foram gerados durante um dia de "simulado", compondo um total de quase 200 textos produzidos por 5 turmas. Dessas cinco turmas, aproximadamente metade dos alunos fazem parte das "minhas turmas", conforme expliquei acima, no item (3).

Para esta pesquisa, serão utilizados apenas textos dos alunos que fazem parte das turmas em que lecionava e que serão chamadas de: Turma A1, Turma B1, Turma C1, Turma D1 e Turma E1.

A primeira seleção de textos - apenas com os alunos que compunham as turmas em que eu lecionava - foi feita em função de eu não ter acesso aos demais alunos para dar sequência aos procedimentos documentais da pesquisa, como as autorizações de pais e dos próprios alunos. Sendo assim, julguei mais apropriado limitar-me aos alunos em que eu tive acesso durante toda a pesquisa (representados pelo universo de participantes na figura 13).

A seguir, há uma representação da maneira como são divididas as turmas e a exposição do total de redações que foram disponibilizadas para esta análise ${ }^{14}$.

\footnotetext{
${ }^{14}$ Para esta análise, considerei apenas as redações que foram autorizadas pelos alunos e seus respectivos responsáveis. Por uma questão de ética, as demais redações foram descartadas.
} 


\begin{tabular}{|c|l|c|c|}
\hline \multirow{2}{*}{ TURMA } & \multicolumn{2}{|c|}{ DIVISÃo } & $\begin{array}{c}\text { Número de } \\
\text { Participantes } \\
\text { da Pesquisa }\end{array}$ \\
\hline \multirow{2}{*}{ A } & Turma A1 - Professora Ana & $\mathbf{2 0}$ alunos & 19 \\
\cline { 2 - 4 } & Turma A2 - Outra professora & 20 alunos & 0 \\
\hline \multirow{2}{*}{ B } & Turma B1 - Professora Ana & $\mathbf{2 0}$ alunos & 19 \\
\cline { 2 - 5 } & Turma B2 - Outra professora & 20 alunos & 0 \\
\hline \multirow{2}{*}{ C } & Turma C1 - Professora Ana & $\mathbf{2 0}$ alunos & 13 \\
\cline { 2 - 5 } & Turma C2 - Outra professora & 20 alunos & 0 \\
\hline \multirow{2}{*}{ D } & Turma D1 - Professora Ana & $\mathbf{2 5}$ alunos & 21 \\
\cline { 2 - 5 } & Turma D2 - Outra professora & 15 alunos & 0 \\
\hline \multirow{2}{*}{ E } & Turma E1 - Professora Ana & $\mathbf{1 5}$ alunos & 11 \\
\cline { 2 - 5 } & Turma E2 - Outra professora & 0 alunos & 0 \\
\hline \multirow{2}{*}{ TOTAL DE ALUNOS PARTICIPANTES DA PESQUISA } & 83 \\
\hline
\end{tabular}

Figura 13 - Número de Participantes da Pesquisa e Divisão de Turmas

No corpus total desta pesquisa estão contabilizadas 83 redações de 5 turmas, produzidas por 83 alunos. Para a análise foram selecionadas, aleatoriamente, 15 redações, três de cada turma. Esta segunda seleção foi fundamental para que eu obtivesse uma amostra que me permitisse fazer uma leitura ainda mais atenta de cada um dos textos de maneira que compusessem um corpus variado.

É importante mencionar que o percentual de redações selecionadas em consideração ao montante total é muito diferente, tendo em vista que algumas turmas possuem apenas 15 alunos e em outras mais de 20. Além disso, devo esclarecer que, embora os alunos venham de turmas diferentes, não há grandes diferenças das aulas oferecidas para uma turma ou outra, além das questões comuns de diversidade de uma sala de aula, ou seja, o conteúdo abordado é o mesmo para todas as turmas, bem como o material didático, os exercícios aplicados e a duração das aulas.

A seguir, disponibilizo o quadro de redações ${ }^{15}$ que estão contempladas nesta pesquisa, o código de identificação do texto e a turma da qual fazem parte.

\footnotetext{
${ }^{15}$ As redações completas constam nos anexos deste trabalho.
} 


\begin{tabular}{|c|l|c|}
\hline Turma & \multicolumn{1}{|c|}{ Título } & $\begin{array}{c}\text { Ordem em } \\
\text { que aparece } \\
\text { na análise }\end{array}$ \\
\hline A1 & A importância da leitura e seus reflexos & 2 \\
\hline A1 & A importância da escrita & 9 \\
\hline A1 & Objetivos pelo estudo & 15 \\
\hline B1 & A importância da escrita & 5 \\
\hline B1 & Escrever bem é o produto da leitura & 8 \\
\hline B1 & Inclusão social & 11 \\
\hline C1 & Canetas e inclusão social & 1 \\
\hline C1 & Educação e evolução & 7 \\
\hline C1 & Os reflexos positivos da capacidade de escrita & 13 \\
\hline D1 & A escrita social & 3 \\
\hline D1 & O caminho para entrar na sociedade & 6 \\
\hline D1 & Inclusão e escrita & 14 \\
\hline E1 & O ciclo da cultura & 4 \\
\hline E1 & Chave para o conhecimento & 10 \\
\hline E1 & O valor atemporal do ensino sistemático & 12 \\
\hline
\end{tabular}

Figura 14 - Redações por título, turma e ordem em que aparecem na análise dos dados

Com a intenção de continuar a apresentar e contextualizar esta pesquisa, na seção a seguir, observaremos a proposta de redação e a maneira como os dados foram gerados.

\section{3}

\section{Geração de dados}

É preciso analisar a maneira como a proposta de redação foi apresentada aos alunos e, também, algumas das múltiplas possibilidades de interpretação da temática da atividade que procurava não direcionar a capacidade reflexiva do aluno, reforçando, ainda a importância de seu posicionamento no texto.

A proposta de redação foi elaborada com três textos motivadores, um artigo da internet, um fragmento de um aluno do Ensino Médio, um texto de um blog e uma imagem, selecionada no “Google Images”. O aluno deveria se posicionar a respeito do ensino da escrita em língua portuguesa na escola e sua importância (ou não) para a inclusão social em um texto do tipo dissertativoargumentativo, de 25 a 30 linhas. Vejamos, a seguir, a proposta na íntegra. 


\section{Proposta de redação}

Muito tem se discutido sobre o ensino e uso da escrita formal em língua portuguesa e sua relação com a inclusão social. Os trechos abaixo selecionados tratam desse tema e têm por objetivo ajudá-lo a refletir sobre essa questão:

Ler e escrever faz parte do cotidiano de todas as pessoas, por isso a sua importância no convívio social. É através do uso da leitura e da escrita que o sujeito vai sentir-se incluso na sociedade e ser caracterizado como cidadão participante. Sabemos que um dos responsáveis pela socialização do individuo é a escola.

(adaptado de Santos, A. O. Disponível em www.artigonal.com em 27/01/2012)

"Acho mesmo que escrever é importante, quer dizer, saber escrever. Só que muita gente se esquece que há muitos artistas, jogadores de futebol e até empresários que nem tem o primeiro grau, mas acumulam muitos milhões em suas contas bancárias. E então, eu me pergunto: será que só escrever bem basta? Será que essa é a salvação? Será que é disso que eu preciso? Eu sei que só nascem um ou dois Sócrates e Pelés no mundo, mas quantas outras pessoas se saem bem sem estudar? Isso se chama 'estrela'. Ou a pessoa tem ou não tem."

(A.L.C. Estudante 3o ano Ensino Médio)

Se, já hoje, uma boa formação no ensino médio é necessária para a plena emancipação e a inserção na força de trabalho, nenhum país pode ter a expectativa de um futuro promissor se empurra para a margem tão grande proporção de seus jovens como nós o fazemos. E, na maioria dos casos, o jovem deixa a escola com um profundo sentimento de não pertença à sociedade e com a autoestima rebaixada, o que afeta profundamente o seu futuro relacionamento com essa mesma sociedade. As consequências estão à vista de todos.

http://blogolitica.blogspot.com/2011/12/ensino-superior-exclusao-privatizacao-e.html

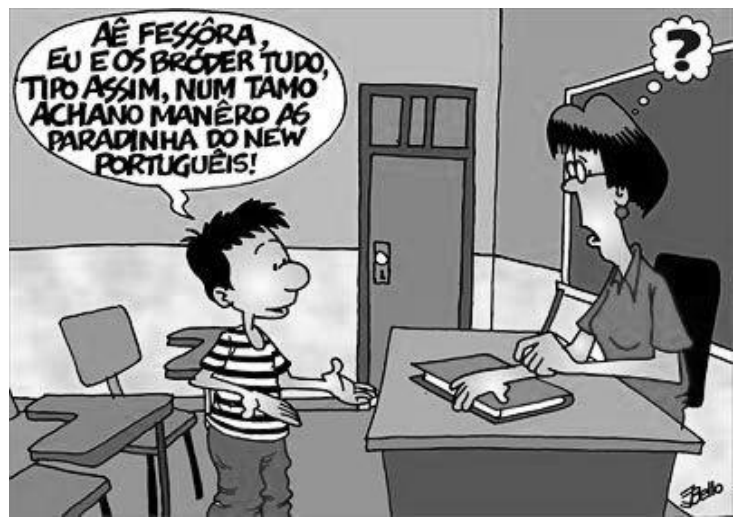

Tendo em vista as perspectivas apresentadas, escreva um texto dissertativoargumentativo, entre 25-30 linhas, refletindo sobre a seguinte questão: Qual é a sua posição sobre o ensino da escrita em língua portuguesa na escola e sua importância (ou não) para a inclusão social? Dê um título criativo a seu texto e organize seus argumentos de forma clara, a fim de defender e sustentar seu ponto de vista. 
Claramente, observam-se duas questões distintas: (1) Qual a sua posição sobre o ensino na escrita na escola? e (2)Esse ensino é importante (ou não é) para promover a inclusão de um indivíduo na sociedade?

Os discentes receberam a proposta em sala de aula e puderam escrever seus textos em dois tempos de aula de cinquenta minutos cada um, logo, construíram seus textos em uma hora e quarenta minutos. Os alunos receberam a coletânea de textos e a folha de resposta, destinada à elaboração da redação, e apenas uma orientação: a de que tecessem seus textos de acordo com seus valores e crenças, e que se posicionassem sinceramente a respeito do tema.

A ausência da discussão sobre o tema da redação foi intencional em função de acreditar que a instituição “escola” já exerce, sobre o aluno, grande influência, e está repleta de papéis a serem desempenhados e relações cristalizadas. Logo, discutir o tema poderia significar orientar as múltiplas visões, realidades, crenças e valores que emergem dos alunos na sala de aula e alcançar uma "respostapadrão”.

Conforme indicado no início desta seção, para que os discentes desenvolvessem o texto, de 25 a 30 linhas, foram oferecidos como texto de apoio três fragmentos e uma charge que não direcionavam ou orientavam os alunos a uma "resposta” desejada. Para tanto, no primeiro fragmento há um depoimento afirmando que a leitura e a escrita são importantes para o cotidiano das pessoas e também para a sua inclusão social, remetendo à escola o papel de agente responsável pela socialização do indivíduo.

Por outro lado, no segundo fragmento há o depoimento de um estudante do $3^{\circ}$ ano do Ensino Médio afirmando que escrever é importante, contudo, pondera que há pessoas sem escolaridade que possuem sucesso financeiro e, por isso, restam dúvidas se a escrita é, realmente, a “salvação” ou o caminho para o sucesso. O aluno comenta que há poucas personalidades ilustres que possuem habilidades que os faz destacar-se, entretanto, para ele há muitas outras pessoas que obtêm sucesso sem estudar e atribui tal conquista à “estrela”, um destino lançado para cada indivíduo que delimitará sua capacidade de se sair bem.

Já no terceiro fragmento de texto escrito não há nenhuma menção à questão da leitura ou da escrita. O fragmento comenta, apenas, da questão da necessidade de uma boa formação do ensino médio e a relação desta formação com a expectativa de um futuro promissor, explicando, ainda, que muitos jovens 
deixam o Ensino Médio sentindo-se marginalizados e que, tal relação, futuramente afetará o relacionamento deste jovem com a sociedade. Este texto foi selecionado por não mencionar a questão da leitura e da escrita, mas sim da formação do indivíduo e sua relação com o futuro, sugerindo uma reflexão sobre a qualidade do ensino e a quantidade de sujeitos que são colocados à margem da sociedade por não possuírem oportunidade de estudar.

Textos de apoio inseridos no gênero discursivo "Redação de Vestibular" possuem, em sua natureza, a intenção de fazer com que os alunos reflitam sobre as questões da temática. Por isso, os dois primeiros fragmentos apontam, contrariamente, para a questão da importância de aprender a ler e escrever para o sucesso de um indivíduo e sua inclusão na sociedade. A maneira como esses fragmentos foram apresentados não teve a intenção de orientar as respostas dos alunos.

A charge incluída na proposta de redação sugere de maneira bastante exagerada, característica do gênero, uma denúncia do que acontece nas salas de aula contemporâneas. Muitas possibilidades de interpretação podem surgir da leitura desta imagem, como a questão da inclusão de palavras estrangeiras no dia a dia de alguns brasileiros, principalmente os jovens. Também é possível refletir sobre a forma de falar do personagem aluno que se dirige à professora em tom bastante informal, fazendo uso de gírias.

Há, ainda, a possibilidade de repensar a relação entre aluno e professora, personagens da charge, que parecem não falar a mesma língua e, por isso, a personagem professora não compreende o que é explicado pelo aluno. Isso apresenta-nos uma crítica ao desnível na comunicação entre alunos e professores que, algumas vezes, fazem uso de registros distintos em sua fala, comprometendo, desta maneira, o entendimento.

Uma interpretação bastante simplista desta imagem poderia sugerir uma crítica-reclamação do aluno quanto às mudanças no acordo ortográfico da língua portuguesa, aprovado em 1990 e, decretado publicamente no Brasil em abril de 1995, e ratificado, posteriormente, em setembro de 2008. Tais elementos textuais na forma escrita e imagética permitem ao aluno ampla reflexão acerca da proposta da redação.

Caberia analisar a interferência da proposta de redação na produção dos textos dos alunos, pois compreendo que certamente há uma relação de resposta à 
questão “Qual é a sua posição sobre o ensino da escrita em língua portuguesa na escola e sua importância (ou não) para a inclusão social?”, mas decidi, aqui, não analisar esta resposta, pois entendo que toda produção de texto do gênero dissertativo-argumentativo (cf. capítulo 2, seção 2.3, p. 41) pretende trazer uma resposta relacionada com o tema da proposta de redação.

\section{4}

\section{Participantes da pesquisa}

Os participantes desta pesquisa são um grupo de alunos, autores dos textos analisados nesta pesquisa e eu mesma, a professora de redação, pesquisadora deste cenário.

\subsection{1}

\section{Autores}

Os alunos que participaram desta pesquisa são oriundos de diferentes contextos socioeconômicos e educacionais, e estão agrupados em turmas diferentes, conforme explicado neste capítulo, na seção 3.2. São estudantes na faixa etária de 16 a 19 anos e, em sua maioria, cursam todo Ensino Médio na mesma escola (desde o primeiro ano), sendo raros os alunos que foram transferidos para o colégio apenas no terceiro ano.

As turmas são compostas de rapazes e moças e, de acordo com a turma, há mais rapazes ou moças. As turmas, como citado anteriormente, são divididas por área do conhecimento, ou seja, a área em que o aluno deseja prestar vestibular e seguir na universidade, não havendo divisão por gênero ou por notas e desempenho. De maneira geral, os alunos são muito receptivos às aulas de Produção Textual, costumam cumprir as atividades escrita e comentam que é importante para o vestibular.

Percebo, também, que as turmas são muito participativas e questionadoras, alguns alunos são mais tímidos, mas a grande maioria gosta de debater os mais diferentes temas de redação.

No momento em que a redação foi aplicada, os alunos não tinham ciência de que aquela redação poderia ser selecionada para uma pesquisa, mas já sabiam 
que estavam participando de um projeto sobre "Escrita e inclusão social: análise da (re)construção identitária no Ensino Médio” em diálogo com o projeto “Escrita e inclusão social: análise de corpus e metáfora gramatical no Ensino Médio”16 pois foram convidados a participar, preencheram os formulários de aceite e levaram os termos de responsabilidade para os responsáveis ${ }^{17}$.

Levo em consideração a trajetória individual de cada aluno na construção do texto dissertativo-argumentativo deste trabalho, pois reconheço a pluralidade da sala de aula, as diferentes necessidades e interesses dos alunos. Depois de produzidos os textos que compõem esta análise e mais no final do ano letivo, tive a oportunidade de discutir com os alunos alguns assuntos que traziam em seus textos, ideias e posicionamentos que construíram e o tema em si, mas estas discussões, embora tenham colaborado para direcionar meu olhar para esta pesquisa, não fazem parte dos dados desta análise.

Alguns alunos gostam de escrever outros tipos de texto diferentes do dissertativo-argumentativo, como poesias e crônicas. Como professora de Produção Textual do segmento escolar em questão, sempre que tenho a oportunidade, costumo estimular a produção de outros gêneros ainda que não sejam o objetivo das aulas de produção textual do terceiro ano do Ensino Médio, em que devemos trabalhar bastante o texto dissertativo-argumentativo que é solicitado pelos exames vestibulares.

Portanto, considero que existam diferenças não apenas no que compete aos aspectos argumentativos, como também diferenças de maturidade, personalidade, valores, construção ideológica e, até mesmo, aptidões para lidar com o texto. Embora esses não sejam objetos centrais desta análise, não podem deixar de ser observados.

\section{4 .2}

\section{Professora, pesquisadora e banca}

No momento da realização desta pesquisa, trabalhava há três anos atuando como professora da instituição e, em minha experiência, reconheço que os alunos

\footnotetext{
${ }^{16}$ Os projetos em questão são coordenados, respectivamente, pelas professoras doutoras Adriana Nogueira Accioly Nóbrega e Lúcia Pacheco de Oliveira, e desenvolvidos na PUC-Rio.

17 Todos os documentos utilizados para a autorização desta pesquisa encontram-se nos anexos.
} 
da escola em questão escrevem de maneira bastante satisfatória no que diz respeito às normas e modelos necessários aos exames vestibulares.

Sou formada em Letras com habilitação em Português e Literatura, mas, em meu percurso como professora, me dediquei ao ensino de produção textual/redação. Sempre tive o interesse de entender melhor a maneira como as pessoas expressam seus valores através da linguagem e a Linguística SistêmicoFuncional foi capaz de esclarecer algumas questões que me intrigavam. Alguns desses interesses são alvos desta pesquisa que procuro desenvolver, como, por exemplo, as maneiras pelas quais podemos potencializar nossos valores, como podemos nos inscrever nos textos de forma mais acintosa e como conceder maior força ao posicionamento do autor. Tenho muito interesse em entender mais sobre as formas de construção do posicionamento do autor pois acredito que a maneira como nos posicionamos pode implicar na nossa inclusão na sociedade de maneira mais ativa e consciente.

Também, em função da disciplina que leciono, sempre me interessei pela construção do processo argumentativo, pois acredito que ele é capaz de colocar todos os indivíduos de maneira igualmente favorável diante de um determinado tema, além de acreditar que através de nosso posicionamento, nossos valores e formas de defender nossos pontos de vista, somos capazes de nos incluir na sociedade de maneira participativa. Quando sabemos realizar nossas escolhas lexicogramaticais de forma consciente, podemos nos expressar com maior clareza e com mais assertividade, de acordo com nossos interesses e propósitos.

Há uma dinâmica no processo de argumentação que pressupõe o reconhecimento do interlocutor. Assim, ao iniciar um processo argumentativo, o autor/falante mune-se de todas as ferramentas necessárias para expor e defender seu ponto de vista de acordo com a audiência que terá. No caso estudado neste trabalho, as redações que simulam os exames de vestibular pressupõem uma audiência reconhecida, nós, professores, que reconhecidamente seremos as "bancas".

Entretanto, existem algumas questões que são suscitadas pelos alunos quando imaginam o Gênero Redação de Vestibular, de fato. Algumas dessas dúvidas, como por exemplo, quem é o interlocutor; quem compõe a banca de correção do vestibular; acabam por orientar a escolha argumentativa dos alunos 
que imaginam que escolhas serão adequadas a um texto quando não reconhecemos a "Banca”.

Esse leitor-banca é institucionalizado e, muitas vezes, os alunos questionaram, em sala de aula, sobre como devem se posicionar diante de temas mais polêmicos, principalmente em vestibulares para instituições militares. Questões como: "Professora, posso falar mal do Governo?, Posso criticar negativamente esse comportamento?”, são muito ouvidas em sala de aula. Isso nos remete a uma questão central: os alunos realmente posicionam-se de acordo com seus pontos de vista ou preparam uma argumentação que deva atender à "Banca”, ainda que não reflitam os seus posicionamentos sobre o tema? Esse também é um ponto que será abordado nesta pesquisa.

\section{5}

\section{Procedimentos de pesquisa e categorias de análise}

Como já mencionado, durante muitos anos trabalhei com o ensino de Produção Textual e, talvez por isso, sempre tive o interesse em conhecer mais sobre o processo de ser autor, de produzir textos, de inscrever nossa própria identidade com o uso das palavras. Entender mais sobre as formas de construção do posicionamento é, para mim, compreender o movimento de ser autor. Portanto o objetivo deste trabalho se alinha com uma questão primeiramente particular, o interesse de alcançar mais entendimentos sobre o tema.

Depois de estudar sobre a LSF e sobre a Avaliatividade, percebi que aliar este conhecimento à Argumentação seria muito produtivo e, daí, surgiu o objetivo de investigar a construção do posicionamento do autor no texto dissertativoargumentativo, alvo da minha trajetória profissional e desta pesquisa.

O primeiro momento da pesquisa surgiu desta necessidade de investigar o posicionamento do autor. Posteriormente, percebi que aliar o contexto da "minha sala de aula” à pesquisa poderia me auxiliar de diversas maneiras, principalmente por ter a oportunidade de retornar aos participantes da pesquisa.

Não tive a oportunidade de analisar os dados com os alunos, mas tive momentos de debate em sala de aula (que, como já dito, não fazem parte desta pesquisa) sobre o resultado dos textos produzidos, ou seja, tendo o produto final, a redação pronta, conversamos sobre a própria experiência de escrever e o 
sentimento deles diante da questão da inclusão social. Como comentado, tais conversas não fazem parte dos dados analisados nesta pesquisa.

Uma vez reunidas as redações, o primeiro procedimento foi o de leitura cuidadosa de todos os textos disponíveis, os 83 exemplares. Não procurei tirar conclusões sobre a qualidade dos textos, mas confesso que foi difícil sair da posição de professora-avaliadora e professora-banca para a posição de participante-pesquisadora.

Depois de uma primeira leitura, selecionei, aleatoriamente, três textos de cada turma, que compuseram uma amostra de 15 redações. Esta seleção foi fundamental para que eu pudesse observar mais detalhadamente cada um dos recursos da Avaliatividade tecendo os movimentos argumentativos dos textos.

Pus-me, assim, a marcar os textos, colorindo trechos cada vez em que o autor fazia uso de um recurso da Avaliatividade para expressar seu posicionamento argumentativo.

O tipo dissertativo-argumentativo possui como característica padrão estabelecer movimentos destinados à distribuição do texto e tais campos são muito bem delimitados e comumente reconhecidos como introdução, desenvolvimento e conclusão. A introdução tem como característica principal destinar-se à apresentação do tema da redação através do ponto de vista do autor, que pode ser chamado de tese. A tese, portanto, reflete o posicionamento do autor diante de um determinado tema proposto na redação.

Para esta análise, serão observados aspectos avaliativos que constroem o posicionamento e, também, a maneira como o aluno fundamenta seus argumentos, oferecendo um posicionamento mais ou menos autoral. Nessa perspectiva, os recursos da Avaliatividade serão necessários à análise, já que é através de elementos avaliativos semânticos e lexicogramaticais que o escritor será capaz de expressar o seu posicionamento. Logo, esta analise procura observar como são alcançados, linguisticamente, os posicionamentos, valores, e crenças dos alunos.

A partir desta etapa da análise, procurei selecionar os parágrafos introdutórios dos textos. Estou ciente de que a Avaliatividade permeia todo o texto e está na prosódia do discurso, mas, ainda assim, selecionei a introdução dos textos em função de nelas conterem as teses dos alunos, ou seja, o espaço em que há um maior posicionamento do autor. Tendo em vista que a tese está situada na introdução e é o local onde o ponto de vista sobre a questão polemica (apresentada 
na proposta de redação) deve estar expresso, procurei situar a análise neste espaço do texto.

A partir desse momento em que (1) foram aleatoriamente selecionados três textos de cada turma, compondo um corpus de 15 redações; (2) foram lidas todas as quinze redações e observado que os recursos da Avaliatividade estavam sendo utilizados para potencializar os pontos de vista dos autores; e (3) foi identificado que as introduções, em função de serem o local onde estão situadas as teses, contam com maior posicionamento do autor e, por isso, seriam um bom espaço para observação das estratégias dos autores, parti para o próximo passo que seria verificar os recursos que eram mais ou menos utilizadas pelos autores, e de que maneira esses recursos eram utilizados.

A produção textual em contextos de ensino-aprendizagem específicos para exames vestibulares considera, frequentemente, as seguintes questões: se o aluno conhece o conteúdo suficientemente para produzir um texto de qualidade (aprofundamento ao tema); o seu conhecimento de mundo (e, se sabe como adaptar tal conhecimento à realidade); se há desvios gramaticais; se o contexto se apresenta de maneira clara; se há argumentos trabalhados com clareza e precisão vocabular; se o texto apresenta coesão entre os elementos gramaticais e entre as ideias expostas; e, por fim, se há uma progressão argumentativa. Este trabalho não pretende avaliar estas questões, embora compreenda que também são importantes no percurso educativo.

O objetivo norteador deste trabalho é investigar a construção do posicionamento do autor em textos dissertativo-argumentativos e com o intuito de desenvolver esta investigação, trago três perguntas de pesquisa:

1. De que forma o posicionamento do autor é expresso nos parágrafos introdutórios dos seus textos?

2. De que maneira o uso dos recursos da Avaliatividade podem ser vistos como possíveis estratégias de argumentação?

3. Que potenciais de significados argumentativos podem ser criados através dos recursos da Avaliatividade? 
Para auxiliar a compreensão das questões que orientam esta pesquisa elaborei três categorias de análise que procuram examinar: (1) a Gradação como elemento potencializador do posicionamento do autor e da argumentação; (2) o Julgamento e a Apreciação atuando como recursos opinativos na construção do posicionamento autoral; e (3) o Engajamento como recurso de concessão de força ao posicionamento e à argumentação.

Tais categorias foram consideradas, pois foi observei que determinados recursos chamaram mais a minha atenção por suas características argumentativas. A Gradação, por exemplo, ao potencializar o posicionamento do autor, indicava um movimento argumentativo mais sólido, o Julgamento realçava o posicionamento do autor e o Engajamento indicava o grau de comprometimento que o aluno decidia ter com suas alegações. Diante dessas primeiras observações, a análise nas introduções das quinze redações foi aprofundada com o objetivo de observar o percurso para a construção do potencial argumentativo e a inscrição do posicionamento do autor.

Nos próprios textos, foram marcados os momentos em que os recursos avaliativos eram utilizados para intensificar determinado argumento, criando um posicionamento mais ou menos inscrito, mais ou menos forte. De acordo com estas observações, as redações foram se organizando da seguinte maneira:

\begin{tabular}{|c|c|l|}
\hline \multirow{4}{*}{ Categoria } & Turma & \\
& & \\
\hline \multirow{3}{*}{$\begin{array}{c}\text { A Gradação como elemento } \\
\text { potencializador do posicionamento do } \\
\text { autor e da argumentação }\end{array}$} & A1 & A importância da leitura e seus reflexos \\
\cline { 2 - 3 } & B1 & A importância da escrita \\
\cline { 2 - 3 } & C1 & Canetas e inclusão social \\
\cline { 2 - 3 } & D1 & A escrita social \\
\hline \multirow{4}{*}{$\begin{array}{c}\text { O Julgamento e a Apreciação atuando } \\
\text { como recursos opinativos na construção }\end{array}$} & E1 & O ciclo da cultura \\
\cline { 2 - 3 } do posicionamento autoral & B1 & A importância da escrita \\
\cline { 2 - 3 } & C1 & Escrever bem é o produto da leitura \\
\cline { 2 - 3 } & D1 & O caminho para entrar na sociedade \\
\cline { 2 - 3 } & E1 & Chave para o conhecimento \\
\hline \multirow{3}{*}{$\begin{array}{c}\text { O Engajamento como recurso de } \\
\text { concessão de força ao posicionamento e }\end{array}$} & A1 & Objetivos pelo estudo \\
\cline { 2 - 3 } à argumentação & B1 & Inclusão social \\
\cline { 2 - 3 } & C1 & Os reflexos positivos da capacidade de escrita \\
\cline { 2 - 3 } & D1 & Inclusão e escrita \\
\cline { 2 - 3 } & E1 & O valor atemporal do ensino sistemático \\
\hline
\end{tabular}

Figura 15 - Agrupamento de redações por categoria de análise 
Analisarei, na próxima seção, os efeitos da Gradação como elemento potencializador do posicionamento e da argumentação. Em sequência, serão analisados dois recursos da Atitude, o Julgamento e a Apreciação na construção do posicionamento do autor, observando de que maneira tais recursos podem potencializar o posicionamento do autor e reforçar a argumentação, e, por fim, as estratégias utilizadas para a concessão de fora ao posicionamento e à argumentação de acordo com o recurso do Engajamento.

Conforme apresentado na Figura 15, esta análise estará ancorada na abordagem da Linguística Sistêmico-Funcional, no Sistema da Avaliatividade e na Teoria da Argumentação. Considero que há uma correlação que integra os tipos de significados que compreendem todo o potencial de significados ao potencial argumentativo.

A seguir, apresentarei a análise das quinze redações tendo como objetivo investigar como os alunos constroem seus posicionamentos, representações, crenças e valores nos textos, como se processa a relação entre sua argumentação e os elementos da Avaliatividade e como os recursos da Avaliatividade atuam como estratégias argumentativas. 


\title{
Análise dos Dados
}

\begin{abstract}
Cada vez que tento "analisar" um texto que me deu prazer, não é a minha "subjetividade” que volto a encontrar, mas o meu "indivíduo", o dado que torna meu corpo separado dos outros corpos e lhe apropria seu sofrimento e seu prazer (...).
\end{abstract}

Roland Barthes (2002, p.73)

Para a análise dos dados, concentro-me no objetivo da pesquisa em investigar a construção do posicionamento do autor em textos dissertativoargumentativos, procurando compreender de que maneira tais posicionamentos estão expressos nos parágrafos introdutórios de seus textos; em como o uso dos recursos da Avaliatividade podem ser vistos como uma possível estratégia de argumentação; e observar que potenciais de significados argumentativos podem ser criados através dos recursos da Avaliatividade baseando-me nas seguintes categorias: (1) a Gradação como elemento potencializador do posicionamento do autor e da argumentação; (2) Julgamento e Apreciação como recursos opinativos na construção do posicionamento autoral; e (3) o Engajamento como recurso de concessão de força ao posicionamento e à argumentação.

Conforme apresentado no capítulo 3, que trata da metodologia desta pesquisa, os parágrafos aqui analisados são considerados parágrafos de introdução, espaços em que, geralmente, as teses e o posicionamento do autor, seu ponto de vista sobre o tema da redação, são manifestados.

Cabe reforçar que fundamento esta análise nos pressupostos teóricos da Linguística Sistêmico-Funcional e do Sistema da Avaliatividade, abordados no capítulo 2. As categorias estabelecidas nesta análise são baseadas em elementos da Avaliatividade que podem funcionar como potencializadores do posicionamento nos textos dissertativo-argumentativos, são eles: a Gradação; o Julgamento e a Apreciação; e o Engajamento.

A categoria da Gradação, conforme veremos adiante, funciona como um elemento potencializador do posicionamento autoral, auxiliando no processo de argumentação; a segunda categoria analisada é a da Apreciação e do Julgamento 
atuando como recursos opinativos na construção do posicionamento autoral como instrumento de construção do posicionamento; a terceira categoria observada nesta pesquisa é a do Engajamento, que, integrado a outro elemento da Avaliatividade, concede maior força ao posicionamento e à argumentação.

É fundamental considerar que os pressupostos teóricos norteadores desta análise consideram o conceito multifuncional da linguagem. Por isso, os textos investigados ao longo deste estudo podem ser utilizados para ilustrar aspectos distintos, visto que tais exemplos também precisam ser compreendidos como parte de um ‘potencial de significados’ (Martin e White, 2005, p.24).

\section{1}

\section{A Gradação como elemento potencializador do posicionamento e da argumentação}

Como veremos na análise dos dados, a Gradação irá potencializar o posicionamento autoral e a força argumentativa de um texto quando aliada a outro elemento da Avaliatividade como um recurso de intensidade ou reforço.

O quadro abaixo apresenta um resumo da relação entre os elementos da Avaliatividade associados à Gradação na estruturação da argumentação, concedendo maior ou menor força à ela, e na construção do posicionamento autoral. Os textos completos, desta análise, podem ser observados junto aos anexos desta pesquisa, contudo, nos deteremos à análise do parágrafo introdutório a seguir.

\begin{tabular}{|c|c|}
\hline \multirow{2}{*}{$\begin{array}{l}\text { APRECIAÇÃO + GRADAÇÃO DE } \\
\text { REFORÇO OU INTENSIDADE }\end{array}$} & POSICIONAMENTO AUTORAL \\
\hline & FORÇA ARGUMENTATIVA \\
\hline \multirow{2}{*}{$\begin{array}{l}\text { JULGAMENTO + GRADAÇÃO DE } \\
\text { REFORÇO OU INTENSIDADE }\end{array}$} & POSICIONAMENTO AUTORAL \\
\hline & FORÇA ARGUMENTATIVA \\
\hline \multirow{2}{*}{$\begin{array}{c}\text { JULGAMENTO + GRADAÇÃO DE } \\
\text { SUAVIZAÇÃO }\end{array}$} & POSICIONAMENTO AUTORAL \\
\hline & FORÇA ARGUMENTATIVA \\
\hline
\end{tabular}

Figura 16 - Categorias - Análise pela Gradação

Poderemos observar, nos exemplos a seguir, que o Julgamento e a Apreciação foram elementos utilizados pelos autores para identificar seus 
posicionamentos, e a Gradação, aliada a esses recursos, pôde funcionar, de acordo com cada estratégia utilizada (intensidade, reforço ou suavização, cf. capítulo 2, seção 2.2.3) como um suporte para potencializar ou atenuar o posicionamento autoral e a força argumentativa no texto.

O primeiro fragmento de texto analisado neste trabalho apresenta características muito significativas na representação dos elementos lexicogramaticais e semânticos fixadores do Julgamento, e nele poderemos perceber o quão estratégico é o uso da Gradação para ampliar o posicionamento autoral no texto.

Veremos a seguir, na Redação 1, Canetas e Inclusão Social, o posicionamento do autor com relação a proposta de redação apresentada nesta análise (Qual é a sua posição sobre o ensino da escrita em língua portuguesa na escola e sua importância (ou não) para a inclusão social? (cf. Anexo 16, p. 142). Já no início do parágrafo o aluno responde à proposta de redação situando que o ensino da escrita é necessário e fundamental, e durante o desenvolvimento e conclusão do texto, que pode ser consultado integralmente nos anexos desta pesquisa, reafirma seu posicionamento sobre tal importância.

\begin{tabular}{|c|l|l|l|}
\hline \multirow{3}{*}{ P1 } & 1 & O ensino da escrita é um componente necessário e fundamental \\
\cline { 2 - 3 } & 2 & em todas as escolas, pois por meio dela que o indivíduo é \\
\cline { 2 - 3 } & 3 & incluído na sociedade, mas, apesar disso, há uma grande \\
\cline { 2 - 3 } & 4 & deficiência neste ponto na educação brasileira. \\
\hline
\end{tabular}

Redação 1. Canetas e Inclusão Social. Turma C1 (cf. Anexo 1, p.127).

Ao informar que o ensino da escrita é necessário e fundamental, o autor usa o Julgamento de estima social, positivo e direto, realizado lexicogramaticalmente através dos adjetivos necessário e fundamental, para oferecer à sua declaração maior intensidade. Por terem uma natureza atributiva, os adjetivos carregam um grande teor avaliativo através da ligação do verbo ser e reforçam a natureza autoral do posicionamento do aluno no texto. Tais escolhas lexicogramaticais podem acentuar o potencial argumentativo do texto, e torná-lo mais convincente. É importante salientar que os textos dissertativoargumentativos do gênero Redação do tipo Vestibular possuem como propósito 
convencer o leitor, por isso, os autores devem propor argumentos persuasivos que indiquem seu ponto de vista.

Entre o Julgamento e a Apreciação existem áreas nebulosas e, em alguns casos, a fronteira entre eles é muito tênue Julgamento e Apreciação podem se sobrepor (cf. capítulo 2, p. 32). A Apreciação atua no sentido de analisar a performance sob o ponto de vista estético, já o Julgamento, como já vimos no capítulo 2, tende a avaliar o comportamento sob o ponto de vista da ética.

No exemplo acima, verificamos que o autor usa o Julgamento de estima social tendo em vista que o ensino da escrita (linha 1) é feito por pessoas, através de instituições, e o aspecto da ética, sob o ponto de vista da moralidade, está centrado na asserção de que é o ensino que faz com que o indivíduo seja incluído na sociedade, ainda que - para o autor - haja uma deficiência da educação brasileira no que tange esta questão.

Há um Julgamento que beira a questão ética da qualidade do ensino no Brasil. O autor, aqui, não está avaliando a questão estética, a performance da educação no Brasil, mas sim depondo contra esta a deficiência da educação brasileira no quesito ensino da escrita, e, ao fazê-lo, utiliza o Julgamento.

$\mathrm{O}$ aspecto paradigmático da linguagem, permitindo selecionar um item em detrimento do outro, é bastante explícito aqui, já que o autor utiliza dois adjetivos (necessário e fundamental, linha 1) e ainda acentua seu posicionamento ao fazer uso da Gradação de intensidade no segundo (fundamental). Dizer que o ensino da escrita é significativo não bastaria ao autor. Para intensificar o seu modo de valorar o ensino da escrita foi importante ir além e fazer uso não apenas do Julgamento, mas da Gradação. Como sabemos, a Avaliatividade é realizada semântica e lexicogramaticalmente (cf. capítulo 2, seção 2.2), e no Parágrafo 1 (P1) da Redação 1 (Canetas e inclusão social) notaremos emergirem tais aspectos.

Neste parágrafo, a Gradação funciona como uma ferramenta de enriquecimento das marcas de Julgamento, podendo tornar o argumento mais convincente e enfático, e, ainda, o reforço da sentença auxilia na potencialização do posicionamento autoral. A Gradação é uma forte aliada na construção da argumentação e do posicionamento do autor associada à outra marca da Avaliatividade na estruturação argumentativa do texto.

A estratégia argumentativa do autor, posicionando a sua tese favoravelmente ao ensino da escrita na escola (1) $O$ ensino da escrita é um 
componente necessário e fundamental em todas as escolas, é quebrada, por meio do argumento de incompatibilidade, isto é, demonstrando que a afirmativa anterior é incongruente à tese principal (cf. capítulo 2, seção 2.4, p. 49), ao explicar que (2) há uma grande deficiência neste ponto na educação brasileira.

A contraposição de ideias é realizada lexicogramaticalmente através dos operadores argumentativos mas e apesar disso (linha 3). Novamente, é atribuída maior intensidade a esta contrariedade de sentenças (1) e (2) com o uso dos operadores argumentativos que indicam a mesma ideia, isto é, a ocorrência de um fato inesperado, a Gradação, neste caso, é lexicogramatical e semântica, pois a repetição da ideia que há nos itens mas e apesar disso amplifica o sentido de contradição que há nos enunciados.

Observando a Gradação no exemplo P1 da Redação 1, notaremos que o Julgamento feito nas linhas 3 e 4, após os operadores argumentativos mas e apesar disso (linha 3), é reforçado através do elemento lexicogramatical grande, em há uma grande deficiência neste ponto na educação brasileira. Mais uma vez, a Gradação funciona como um forte recurso para dar maior ênfase ao posicionamento do autor no texto que, em vez de declarar que há deficiência na educação brasileira, escolhe nos levar a perceber que há uma grande deficiência.

O posicionamento autoral pode ser enfatizado, ampliado ou amenizado no texto através de recursos da Gradação associados à outra marca da Avaliatividade. Quando o autor pretende se posicionar mais assertivamente, potencializa seus pontos de vista com o uso de elementos lexicogramaticais e semânticos que nos levarão a perceber o quão mais forte podem ser seus pareceres diante de uma avaliação.

Vejamos a força argumentativa do texto quando reescrito sem os elementos da Gradação mencionados anteriormente: $\mathbf{O}$ ensino da escrita é um componente das escolas, pois por meio dela que o indivíduo é incluído na sociedade, mas, há uma deficiência neste ponto na educação brasileira. Notamos na sentença modificada, que a argumentação é enfraquecida, pois os enunciados perdem a assertividade e onde havia a contradição, marcada pelo item lexical mas (linha 3), entre uma afirmativa e outra, parece ter sido amenizada. Tal estratégia funcionaria para abrandar o posicionamento do autor no texto. Uma coisa é dizer que há uma grande deficiência, comprometendo-se ao máximo com a afirmativa acentuando a gravidade do problema, conforme feito pelo autor da 
Redação 1, outra coisa é dizer que há uma deficiência, que pode ou não ser grande, deixando o leitor decidir qual o tamanho do problema.

Veremos no fragmento abaixo, na Redação 2 da Turma A1, mais um exemplo dos elementos da Gradação na estruturação argumentativa do texto, quando associada a outra marca da Avaliatividade, tornando o posicionamento do autor mais ou menos presente no texto.

O autor da Redação 2 defende o ponto de vista de que a leitura é imprescindível para a vida e para o mercado de trabalho, mas as escolas não respondem a essa necessidade de maneira satisfatória.

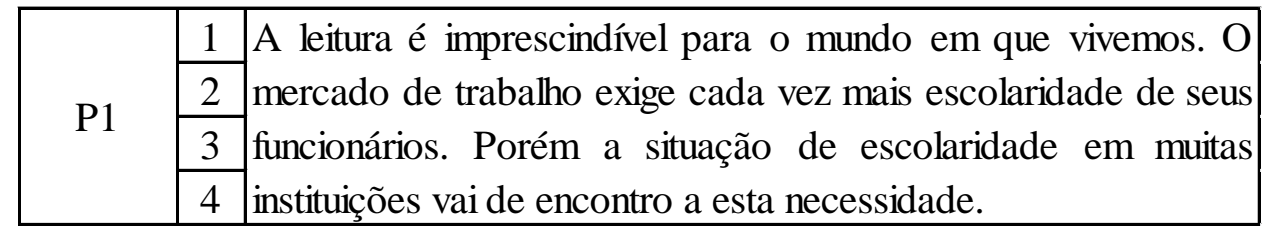

Redação 2. Importância da leitura e seus reflexos. Turma A1 (cf. Anexo 2, p.128).

O autor decide começar seu texto comentando a importância da leitura, afastando-se, de certa forma, da proposta de redação que tratava da questão da escrita para a inclusão social. Ainda assim, veremos como se constrói seu posicionamento, já que prepara o leitor para que ele seja capaz de elaborar a relação entre a leitura e a escolaridade, o mercado de trabalho e a inclusão social.

Ao informar, na linha1, que a leitura é imprescindível para o mundo em que vivemos, o autor utiliza a Gradação de reforço no adjetivo imprescindível para oferecer mais força ao Julgamento de estima social, direto e explícito ao atribuir que a leitura é imprescindível. Para ele, a leitura é mais do que importante no mundo em que vivemos, é imprescindível. Percebemos que a Gradação funciona como um reforço do Julgamento, levando o leitor a compreender o tamanho da importância que a leitura tem para o autor, tal força imprime um posicionamento mais autoral e mais expresso no texto.

Mais uma vez, é importante ressaltar que elementos lexicais como leitura, ensino e escrita, podem ser vistos como performáticos ou comportamentais, isto é, podem ser compreendidos como diferentes elementos da Avaliatividade. Em algumas situações, avaliadas como reações estéticas relacionadas à performance, compreendemos tais elementos como Apreciação, quando nos deparamos com 
aspectos comportamentais que desvelam reações éticas, considero que há Julgamento.

No exemplo acima, podemos entender que a leitura é uma prática realizada por pessoas (isto é, além de comportamental pode ser performática) e, por isso, poderíamos considerar que há um princípio da Apreciação neste elemento. Porém, o que o autor pretende não é valorar a leitura como imprescindível, apenas, sua intenção está além da questão estética e caminha para os princípios éticos quando a seguir, confirma que a situação de escolaridade em muitas instituições vai de encontro a esta necessidade (linhas 3 e 4), fazendo uso do Julgamento de estima social.

O autor continua a fazer uso da Gradação de intensidade na declaração de que o mercado de trabalho exige cada vez mais escolaridade de seus funcionários, há uma ampliação da ideia de que o mercado de trabalho exige escolaridade. A proporção é aumentada com o uso de cada vez mais (linha 2), novamente há o posicionamento autoral e bastante firme no texto.

O fato de o aluno decidir fazer uso do processo exige faz com que ele ofereça ainda mais força à Gradação. O significado de exigir é classificado no dicionário Aulete Digital como:

(1) Requerer (algo) em função de direito fundado ou suposto; REIVINDICAR. [td.: exigir obediência.] [tdr. + a, de: Todo professor deve exigir aos/dos alunos respeito.] Impor (algo) a (alguém), usando autoridade ou direito; (2) IMPOR; ORDENAR. [td.: O presidente da sessão exigiu que se cumprisse a orem do dia.] [tdr. + a, de: Injuriado pela petulância do filho, o pai exigiu -lhe respeito.] (3) Estipular por meio de regras, normas; ESTABELECER; PRECEITUAR. [td.: O regulamento exige que assinemos o ponto diariamente.] (4) Ter necessidade de; PRECISAR; REQUERER. [td.: Toda criança exige cuidados especiais. Antôn.: prescindir.] (5) Solicitar de modo exigente, autoritário; ORDENAR. [tdr. + de: Exigiu do filho uma explicação.] (Dicionário contemporâneo da língua portuguesa Caldas Aulete, Francisco J. Caldas Aulete/Antonio Lopes dos Santos Valente, Edição brasileira original: Hamílcar de Garcia)

Se fôssemos atribuir extremos para o vocábulo exigir, mantendo sua definição, em termos sinônimos, teríamos os seguintes sentidos:

(1) o mercado de trabalho exige cada vez mais escolaridade de seus funcionários (Redação 2, Turma A1, linhas 1, 2 e 3). 
(2) o mercado de trabalho necessita, cada vez mais, de escolaridade de seus funcionários.

(3) o mercado de trabalho precisa, cada vez mais, de escolaridade de seus funcionários.

Notamos que há maior potencial argumentativo no exemplo (1) o mercado de trabalho exige cada vez mais escolaridade de seus funcionários (Redação 2, Turma A1, linhas 1, 2 e 3), na Gradação que há no processo exige. E, por outro lado, menor força no exemplo (3), no processo precisa. Isso nos demonstra o quão posicionado está o aluno na atribuição de sentido que deseja estabelecer ao informar que há uma necessidade extrema e até mesmo imperativa de ter escolaridade.

Quando o autor continua sua construção argumentativa fazendo uso do argumento de incompatibilidade (cf. capítulo 2, seção 2.4, p. 49), marcado pelo operador argumentativo porém (linha 3) no inicio da sentença, ameniza seu comprometimento no texto através do recurso da Gradação, lexicogramaticalmente realizado pelo elemento muitas (linha 3), ao afirmar que $a$ situação de escolaridade em muitas instituições vai de encontro a esta necessidade. Há uma incompatibilidade moral denunciada na expressão vai de encontro, que é suavizada pelo recurso da Gradação em muitas instituições.

Ao situar que são muitas, mas não são todas, as instituições que não oferecem a escolaridade adequada àqueles que estão à procura de um emprego, o autor suaviza o foco e torna pouco precisa sua alegação (quais são as instituições? de quantas escolas estamos falando?). Com isso, há a redução do potencial argumentativo e um distanciamento do autor, não se comprometendo com as ponderações que os leitores farão a respeito de tais instituições.

Há um Julgamento que revela a irregularidade das instituições de ensino com relação à situação da escolaridade, mas ele está implícito e menos forte do que no exemplo anterior (Redação 1 - Turma C1 - título: Canetas e inclusão social) quando a Gradação no elemento lexical funciona para acentuar o posicionamento autoral. Neste exemplo (Redação 2 - Turma A1 - título: Importância da leitura e seus reflexos), percebemos que a Gradação quando utilizada para suavizar a declaração pode levar a um posicionamento menos autoral. 
No fragmento seguinte, na Redação 3 da Turma D1 (Título: A escrita social), analisaremos a maneira pela qual o autor se posiciona no texto e que tipo de estratégias recorre para estruturar sua argumentação, e observaremos a importância da Gradação na construção do posicionamento do autor.

O escritor começa seu parágrafo de introdução oferecendo ao leitor declarações de simples adesão. São informações bem preliminares, posicionadas no argumento de analogia (cf. capítulo 2, seção 2.4, p. 50), já que, para ele, falar é importante para ser incluído, e, por isso, escrever também é (linha 1). Esta ponderação representa, por si só, uma forma de avaliação que o autor deseja julgar como correta, há uma coerência interna nas afirmativas validadas através da semelhança entre as duas sentenças (se A é uma letra, B também é).

Vejamos a seguir a introdução da Redação 3:

\begin{tabular}{|c|c|l|l|}
\hline \multirow{4}{*}{ P1 } & 1 & Se falar é importante para ser incluído, escrever também é. \\
\cline { 2 - 2 } & 2 & Atualmente a maioria da população do planeta vive em cidades, \\
\cline { 2 - 2 } & 3 & e em todas elas é necessário saber se expressar para se \\
\cline { 2 - 2 } & 4 & conseguir o que deseja. É importante visualizar a escrita não \\
\cline { 2 - 2 } & 5 & somente como uma forma de expressão, mas como um \\
\cline { 2 - 2 } & 6 & importante fator do aspecto intelectual. \\
\hline
\end{tabular}

Redação 3. A escrita social. Turma D1 (cf. Anexo 3, p.129).

Neste primeiro movimento argumentativo, a estratégia proposta pelo autor é dotada de declarações que repousam em afirmações comuns, conforme constataremos na continuação das linhas 2,3 e 4, quando o aluno ilustra que $a$ maioria da população do planeta vive em cidades, e em todas elas é necessário saber se expressar para se conseguir o que deseja.

Ocorre um enfraquecimento do potencial argumentativo do texto quando sua premissa está baseada em uma informação acentuada pelo recurso da Gradação de suavização, pois para ele a maioria da população vive em cidades, e em todas as cidades é necessário saber se expressar. Portanto, é possível supor que para aqueles que não vivem em cidades não é necessário saber se expressar, logo, não são todos os que precisam desta habilidade, moradores do campo, por exemplo, podem não ser incluídas neste universo de pessoas.

A Gradação de suavização realizada lexicogramaticalmente na locução $a$ maioria enfraquece o enunciado do autor levando-o a uma premissa inválida de 
acordo com suas escolhas argumentativas anteriores para elaborar uma analogia entre os fatos apresentados.

Quando Oscar Wilde, célebre autor irlandês, citou no seu livro The soul of man under socialism (1950, p 9) que "Viver é a coisa mais cara do mundo. A maioria das pessoas não faz mais do que existir” pretendia, com sua crítica, ponderar que há pessoas que são capazes de fazer mais do que, simplesmente, existir, por isso fez uso da suavização em a maioria. Ao utilizar tal forma, somos capazes de nos resguardar de uma generalização que pode nos levar a incorrer em graves erros de Julgamento.

Contudo, na situação criada pelo autor da Redação 3, a suavização da sentença que repousa no item a maioria, causou uma incoerência argumentativa interna de acordo com as analogias propostas anteriormente. Se falar é importante para ser incluído, e escrever também é, e, além disso, é necessário saber se expressar para se conseguir o que deseja, é importante que todos saibam se expressar para serem incluídos e não apenas os que vivem em cidades.

No mesmo parágrafo em que vimos um afastamento do autor no texto e o potencial argumentativo é enfraquecido, há, na declaração seguinte, um reforço do posicionamento autoral ao associar a Gradação de intensidade em não somente (linhas 4 e 5) e a Gradação de reforço em importante (linhas 4 e 6) a outro elemento da Avaliatividade.

A Apreciação positiva que o autor faz ao enunciar que é importante visualizar a escrita não somente como uma forma de expressão, mas como um importante fator do aspecto intelectual (linhas 4, 5 e 6) nos permite identificar seus valores ao ver a escrita esteticamente. Para ele, a escrita é mais do que uma forma de expressão, ela compõe o aspecto intelectual. Além disso, há novamente o auxílio da Gradação de reforço para aumentar o posicionamento autoral quando orienta o leitor quanto à importância da escrita, ela não é apenas um fator do aspecto intelectual, mas um importante (linha 6) fator.

As observações anteriores nos levam a concluir que ao selecionar a estratégia argumentativa mais eficiente para o texto que se deseja produzir, o escritor deve articular os recursos de Gradação com o propósito de posicionar-se mais fortemente no texto e não abrir espaço para alegações contrárias ou incoerências argumentativas. Ao selecionar o recurso da Gradação inadequado o autor pode perder o fio condutor responsável pela construção dos sentidos no 
relacionamento entre leitor-texto, levando-o a outros significados que não o desejado.

A seguir, veremos outro exemplo da mesma condução argumentativa com o argumento de analogia (cf. capítulo 2, seção 2.4, p. 50), com a intenção de entender como é construído o posicionamento autoral e que mecanismos podem ser responsáveis por estabelecer a força argumentativa.

No fragmento a seguir, da Turma E1, Redação 4 desta análise, o aluno pretende construir sua argumentação através das relações de comparação e aproximação, recorrendo ao argumento de analogia. Para o autor, a imagem do Brasil no cenário internacional é contrária a realidade vivida no país, e em sua tese de que é necessário saber se expressar (através da fala e da escrita) para se conseguir o que deseja e compreender a escrita como um importante fator do aspecto intelectual (linha 6) justifica que a escassez da escrita é reflexo desta contrariedade. O autor tece seus pontos de vista baseando-se na comparação entre imagem e realidade.

\begin{tabular}{|c|c|c|}
\hline \multirow{7}{*}{ P1 } & 1 & \multirow{7}{*}{$\begin{array}{l}\text { Analisando a imagem do Brasil no cenário internacional atual, } \\
\text { pode-se perceber que o país é fortemente representado como } \\
\text { "País do Futebol”, "País do samba”, uma das dez maiores } \\
\text { economias do mundo. Também é de conhecimento geral, } \\
\text { contudo, a alta desigualdade social e o baixo IDH a que a } \\
\text { população brasileira tem se submetido. Tais fatores explicam a } \\
\text { escassa relação entre essa sociedade e a produção escrita. }\end{array}$} \\
\hline & 2 & \\
\hline & 3 & \\
\hline & 4 & \\
\hline & 5 & \\
\hline & 6 & \\
\hline & 7 & \\
\hline
\end{tabular}

Redação 4. O ciclo da cultura. Turma E1 (cf. Anexo 4, p.130).

Lexicogramaticalmente, a realização de analogia se dá primeiramente no operador argumentativo contudo (linha 5), que introduz uma ideia contrária. Para o autor, o Brasil é representado como país do samba e do futebol, no cenário internacional, além de ser uma grande economia, contudo, há, no país, desigualdade social e baixo desenvolvimento humano. Também lexicogramaticalmente, a relação de comparação continua a se estabelecer através de outros recursos, como o uso do nome relação, em a escassa relação entre essa sociedade e a produção escrita (linhas 6 e 7), acentuando que há uma relação entre a questão vivida pela sociedade e a produção escrita. 
Observamos, no P1 da Redação 4, que o autor compromete-se bastante com suas alegações quando utiliza a Gradação de intensidade ao empregar os termos fortemente (linha 2) em o país é fortemente representado como "País do Futebol”, “País do samba”, uma das dez maiores economias do mundo (linhas 2, 3 e 4), e alta e baixo (linha 5) para aumentar a força de seu Julgamento de estima social no fragmento é de conhecimento geral, contudo, a alta desigualdade social e o baixo IDH a que a população brasileira tem se submetido (linhas 4, 5 e 6), ainda que não opte pela primeira pessoa do discurso, provavelmente por uma questão meramente metodológica de adequação a alguns concursos para os quais tem se preparado.

Quando o autor faz as escolhas em questão, conduz seu leitor a concordar com o fato de que o Brasil é fortemente representado desta maneira, como país do samba e futebol. Essa imagem do país é cristalizada, como um princípio no qual não há espaço para incerteza, dúvida ou contradição.

Depois de estabelecer o contraste entre suas alegações com o uso da conjunção contudo (linha 5) - levando-nos a compreender a analogia entre o fato da nação ser representada internacionalmente como país do samba e do futebol, de economia representativa, e, apesar disso, paradoxalmente, ser terra de desigualdade e baixo desenvolvimento humano - o autor seleciona o recurso da Gradação, nos termos alta desigualdade e baixo IDH (linha 5), para nos levar a compreender o quão exorbitante é a relação entre uma sentença e outra. Somos impelidos, novamente, a concordar com a argumentação e posicionamento do autor, uma vez que a Gradação nos empurre para esta concordância.

Logo, ao analisar a imagem do Brasil no cenário internacional, vemos que o país é fortemente representado como "País do Futebol”, "País do samba”, uma das dez maiores economias do mundo, e isso é ótimo, mas também vemos que há uma alta desigualdade social e baixo IDH, e isso é péssimo. Através dos recursos da Gradação na construção argumentativa do texto, somos levados a compreender o porquê de existir uma escassa relação entre essa sociedade e a produção escrita, pois há pessoas que vivem a contradição que existe no país, a mesma contradição anteriormente reforçada na oposição entre alta e baixo (linha 5).

O Julgamento de estima social, estabelecido semanticamente, vai de um extremo positivo, como "País do Futebol", "País do samba”, uma das dez maiores economias do mundo, (linhas 3 e 4) até o extremo negativo da sanção 
social, a alta desigualdade social e o baixo IDH a que a população brasileira tem se submetido (linhas 5 e 6), que refletem a injustiça que existe neste cenário. A Gradação de intensidade, aqui, funciona para oferecer maior ênfase à argumentação e identificar ainda mais fortemente o posicionamento do autor.

Com base na análise das teses, que são estruturadas nos parágrafos de introdução das redações desta análise, podemos observar como os autores se posicionam, quais são as estratégias usadas para oferecer mais força na construção argumentativa dos textos e quais são as melhores alternativas para persuadir e convencer o leitor.

No trecho seguinte, na introdução da Redação 5 da Turma B1, veremos a intenção do autor em pontuar seus valores através dos elementos da Avaliatividade, quais são as estratégias que o apoiam na construção do potencial argumentativo e de que maneira ele acentua ou enfraquece seu posicionamento através da Gradação dos elementos lexicogramaticais.

\begin{tabular}{|c|c|c|}
\hline & & \multirow{4}{*}{$\begin{array}{l}\text { Ler e escrever bem não é importante só para se ter uma boa } \\
\text { formação, é necessário também para que se possa exercer } \\
\text { influência sobre o meio social em que se vive. Porém, as } \\
\text { escolas não dão a merecida atenção a produção textual. }\end{array}$} \\
\hline & & \\
\hline & & \\
\hline & & \\
\hline
\end{tabular}

Redação 5. A importância da escrita. Turma B1 (cf. Anexo 5, p.131).

Em Ler e escrever bem não é importante só para se ter uma boa formação (linha 1), o Engajamento ${ }^{18}$ criado através da negativa no início da declaração rompe com a estrutura lógica da sentença e pode gerar curiosidade para a leitura do fragmento. Conforme observado na Figura 9 de resumo dos recursos do Engajamento (cf. capítulo 2, subseção 2.2.2, p. 38), o Engajamento pela negação contraria a expectativa do leitor, rompendo com o esperado e propiciando modos pelos quais os "recursos linguísticos agem para inscrever o leitor no texto" (Martin e White, 2005, p. 95). Os operadores argumentativos pontuados lexicogramaticalmente pelos itens não (...) só (linha 1) e também (linha 2) oferecem uma quebra de expectativa na leitura do parágrafo e introduzem uma ideia nova, diferente do que pode ser esperado pelo pensamento ideológico de que ler e escrever é importante na formação dos indivíduos.

\footnotetext{
${ }^{18}$ Os recursos avaliativos do Engajamento serão analisados de maneira mais aprofundada na seção 4.3.
} 
O autor vai além do esperado, não basta ter boa formação, é importante exercer influência sobre o meio social em que se vive. Tal estratégia oferece ao texto um posicionamento bastante autoral e direto, o autor se afasta da trivialidade, ele rompe com o que poderia ser esperado pelo leitor e o leva além do senso comum.

Os adjuntos que operam como operadores argumentativos não (...) só (linha 1) oferecem uma Gradação de reforço, esvaziando a importância da afirmativa que repousa no senso comum (de que é importante ler e escrever para a formação das pessoas) e leva o texto para outra direção. Se, do contrário, o autor tivesse escolhido dizer que ler e escrever é importante para a formação dos indivíduos, mas isso é pouco, é importante ir além, é importante se sentir influente, é importante saber influenciar o meio em que se vive, a coerência na estrutura das sentenças, encadeadas, poderia levar a um questionamento sobre se é suficiente ter boa formação ou se é preciso algo além disso.

Já com a Gradação de reforço no operador argumentativo, dizendo que Ler e escrever bem não é importante só para se ter uma boa formação (linha 1), mas, é necessário também para que se possa exercer influência sobre o meio social em que se vive (linhas 2 e 3), a importância de exercer influência no meio em que vivemos é potencializada. Aqui a Gradação funciona como um recurso potencializador do argumento de retorsão, que se constrói na réplica ou contradição dos argumentos do interlocutor e, por isso, utiliza vozes intertextuais que indicam a contraposição de ideias (cf. capítulo 2, p. 49), passa se localizar na importância de exercer influência na sociedade em que vivemos.

No enunciado seguinte, construindo seu posicionamento através do Julgamento de estima social, o autor pontua que as escolas não dão a merecida atenção a produção textual (linhas 3 e 4), justificando que, para ele, a atenção destinada a esta disciplina deveria ser maior, mais importante. Para auxiliar o autor neste processo de convencimento (de que a atenção destinada à produção textual não é suficiente) há novamente o emprego do recurso da Gradação de reforço no atributo merecida (linha 4) para potencializar seu posicionamento e levar o leitor a se alinhar com seu argumento.

Da análise dos parágrafos de introdução das redações (1, 2, 3, 4 e 5), vimos que o posicionamento de caráter avaliativo se mostra como uma ferramenta fundamental para o potencial argumentativo já que, quando há a associação do 
elemento da Atitude acentuado por um elemento da Gradação, o posicionamento e a força argumentativa são potencializados. Portanto, o efeito da Avaliatividade nesta análise pode ser ilustrado conforme a Figura 16, abaixo, como proposto no início desta subseção.

\begin{tabular}{|c|c|}
\hline \multirow{2}{*}{$\begin{array}{l}\text { APRECIAÇÃO + GRADAÇÃO DE } \\
\text { REFORÇO OU INTENSIDADE }\end{array}$} & POSICIONAMENTO AUTORAL \\
\hline & FORÇA ARGUMENTATIVA \\
\hline \multirow{2}{*}{$\begin{array}{l}\text { JULGAMENTO + GRADAÇÃO DE } \\
\text { REFORÇO OU INTENSIDADE }\end{array}$} & POSICIONAMENTO AUTORAL \\
\hline & FORÇA ARGUMENTATIVA \\
\hline \multirow{2}{*}{$\begin{array}{c}\text { JULGAMENTO + GRADAÇÃO DE } \\
\text { SUAVIZAÇÃO }\end{array}$} & POSICIONAMENTO AUTORAL \\
\hline & FORÇA ARGUMENTATIVA \\
\hline
\end{tabular}

Figura 16 - Categorias - Análise pela Gradação

Nos primeiros cinco parágrafos de introdução dos textos selecionados nesta análise, com foco na observação dos recursos da Gradação, especificamente, os recursos da Avaliatividade funcionaram (aliados ao potencial argumentativo) para reforçar o posicionamento autoral. Apenas quando o recurso de Gradação selecionado foi o de suavização, diminuiu-se o foco da argumentação em determinada alegação e houve uma redução da força argumentativa. A construção do posicionamento autoral e da força argumentativa foi evidenciada. Tais elementos podem ser mais ou menos fortes de acordo com as escolhas semânticas e lexicogramaticais das quais os autores, responsáveis pelo envolvimento do leitor na interpretação do texto, fazem uso, conforme é proposta pela abordagem Sistêmico-Funcional ao considerar a linguagem como um sistema de construção de significados que partem de escolhas paradigmáticas. Percebemos, além disso, que a construção do posicionamento autoral e da força argumentativa repousa nos elementos da Gradação, em associação a outros elementos da Avaliatividade.

Na seção a seguir, notaremos a segunda categoria de análise desta pesquisa, observando como a Apreciação e o Julgamento contribuem para construir o posicionamento autoral e de que maneira há concessão de força ao potencial argumentativo dos textos. 


\section{2 \\ Apreciação e Julgamento - recursos opinativos na construção do posicionamento autoral}

A segunda parte desta análise tratará da Apreciação e do Julgamento. Como vimos no capítulo 2, a Apreciação é um dos três grandes campos dos significados da Atitude e é utilizada para avaliar fenômenos através de referências de valor indicando qualidades estéticas, quando apreciamos atribuímos um determinado valor estético ao objeto apreciado. Já o Julgamento trata de qualidades éticas, indicando determinado valor ao comportamento humano. Neste ponto da análise estou interessada em observar de que maneira o Julgamento e a Apreciação são instanciações na construção de pilares argumentativos, como funciona a construção do posicionamento do autor com tais elementos da Avaliatividade considerados como recursos opinativos e críticos, a forma como ativam avaliações positivas e negativas de um determinado enunciado de acordo com a maneira como o recurso foi utilizado.

Existem algumas áreas a serem amplamente estudadas em relação ao Sistema da Atitude. Em algumas situações já se observou que o léxico aplicado ao Julgamento pode ser o mesmo utilizado para a Apreciação. Para esta pesquisa considero que os aspectos semânticos vinculados ao léxico são capazes de fornecer as implicações e inferências necessárias para classificar os elementos atitudinais.

A proposta de redação apresentada aos alunos não faz parte de uma seção exclusiva de análise, mas cabe mencionar que a própria pergunta lançada para os alunos-autores é permeada pela Avaliatividade. Quando questionamos os alunos sobre qual é a sua posição sobre o ensino da escrita em língua portuguesa na escola e sua importância (ou não) para a inclusão social, estamos inferindo que há, para a segunda parte desta pergunta (sua importância, ou não, para a inclusão social), uma resposta afirmativa ou negativa. Dessa maneira, há o convite para que o autor além de se posicionar a respeito do tema, ofereça uma resposta à esta questão.

Quando fazemos uma pergunta como esta, buscamos um posicionamento por parte do autor, de alguma maneira ele deverá refletir sobre essa importância e responder, apresentando seu ponto de vista. Os componentes da Apreciação e do 
Julgamento surgem como elementos opinativos e críticos na construção deste posicionamento como veremos, a seguir, no primeiro parágrafo da Redação 6, da Turma D1, de título O caminho para entrar na sociedade.

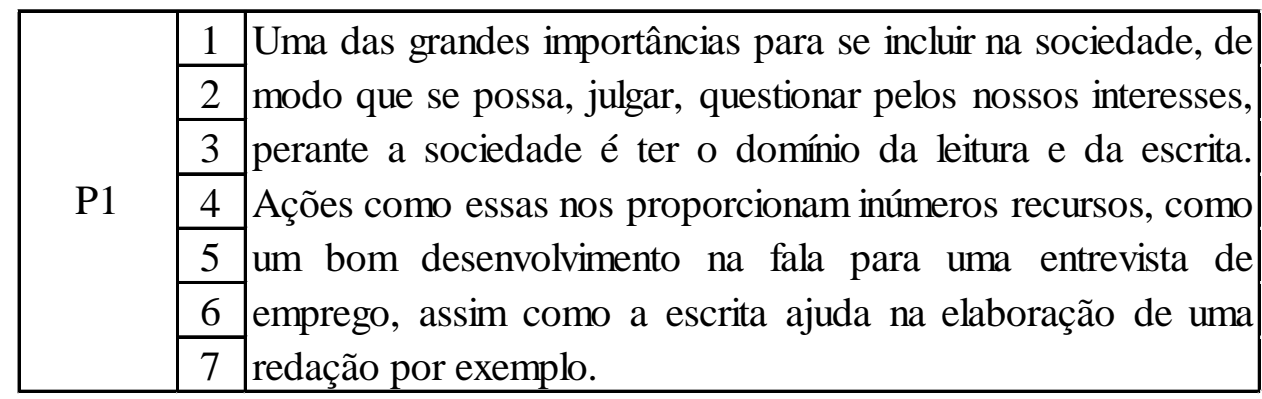

Redação 6. O caminho para entrar na sociedade. Turma D1 (cf. Anexo 6, p.132).

Neste parágrafo (Redação 6, Turma D1), observaremos que o autor constrói sua argumentação de maneira progressiva já que suas escolhas nos mostram que a cada sentença há a inclusão de uma nova informação ao texto, ampliando, desta forma, a sua compreensão. Para isso, o autor utiliza o argumento da definição em Uma das grandes importâncias para se incluir na sociedade (...) é ter o domínio da leitura e da escrita (linhas 1 a 3), e de exemplificação em como um bom desenvolvimento na fala (...), assim como a escrita (...) por exemplo (linhas 4 a 7).

Ao estruturar a sua argumentação, o escritor recorre aos recursos da Avaliatividade para instanciar suas críticas e opiniões a respeito do tema, como podemos observar no primeiro período do texto, quando aplica o recurso da Gradação de reforço, em grande importância (linha 1), da Apreciação em ter o domínio da leitura e da escrita (linha 3), e do Julgamento de estima social em para se incluir na sociedade, de modo que se possa, julgar, questionar pelos nossos interesses (linhas 1 e 2).

Ao atribuir grande importância ao domínio da leitura e da escrita, o autor faz uso de diferentes recursos da Avaliatividade que oferecem ao texto o aspecto crítico que propicia um maior posicionamento autoral e maior força ao potencial argumentativo. Ao avaliar positivamente os efeitos da leitura e da escrita para a inclusão social, o escritor se posiciona como um defensor destas habilidades.

O primeiro elemento lexical que apresenta Gradação está no uso da palavra grandes (linha 1) para reforçar a importância de ter o domínio da leitura e 
da escrita para se incluir na sociedade. Também no uso de domínio (linha 3) há Gradação, já que a expressão, por si só, já é um elemento graduado. O autor poderia dizer que uma das grandes importâncias para se incluir na sociedade (linha 1) é conhecer/aprender a leitura e a escrita. Entretanto, ao fazer uso do termo domínio, em ter o domínio da leitura e da escrita (linha 3), para potencializar seu posicionamento, indicando o quão importante é este conhecimento.

Quando seleciona o item lexical graduado domínio (linha 3), o autor também utiliza o recurso da Apreciação para indicar que há uma análise da performance do indivíduo que precisa ter excelência no processo de leitura e escrita para se incluir na sociedade, portanto, uma das grandes importâncias para se incluir na sociedade (linha 1) é ter o domínio da leitura e da escrita (linha 3). Neste caso, há o uso da Apreciação, pois estamos tratando de qualidades estéticas vinculadas a avaliação da realização de um trabalho humano e não de uma questão meramente comportamental.

Para ilustrar o quão próximos podem estar os elementos da Avaliatividade e como, em alguns casos, se complementam, no mesmo período em que vimos os efeitos da Gradação e da Apreciação na construção argumentativa do texto. O autor seleciona o Julgamento, quando utiliza a expressão de modo que se possa, julgar, questionar pelos nossos interesses, perante a sociedade (linhas 1 a 3). Há uma avaliação do comportamento esperado, isto é, o escritor julga a habilidade e capacidade daqueles que pretendem se incluir na sociedade. Para ele, julgar, questionar em favor dos nossos interesses é importante, são elementos de inclusão e comportamentos positivos esperados daqueles que possuem uma conduta aprovada positivamente pelo escritor.

O autor continua fazendo uso do Julgamento de estima social quando comenta que ações como essas nos proporcionam inúmeros recursos (linha 4) situando o leitor quanto à validade de atitudes como as citadas, declarando-as como condutas validadas socialmente como corretas, são positivas.

Daí em diante, o escritor fará uso da Apreciação positiva para exemplificar quais são as qualidades estéticas provenientes de uma conduta avaliada como a mais adequada: (1) um bom desenvolvimento na fala para uma entrevista de emprego (linhas 5 e 6) e (2) a escrita ajuda na elaboração de uma redação 
(linhas 6 e 7). Falar bem e escrever bem são fatores que auxiliam o indivíduo na sua inclusão social.

No parágrafo P1 da Redação 6, os posicionamentos do autor e de sua orientação argumentativa são construídos através de três elementos da Avaliatividade, que funcionam como recursos críticos e opinativos, e indicam o sentimento do autor em relação à questão temática: qual é a sua posição sobre o ensino da escrita em língua portuguesa na escola e sua importância (ou não) para a inclusão social? (cf. Anexo 16, p. 142).

Observaremos, no próximo excerto analisado, o Parágrafo 1 da Redação 7, da Turma C1, em que o Julgamento funciona como justificativa da tese do autor tendo um espaço fundamental na construção argumentativa do texto.

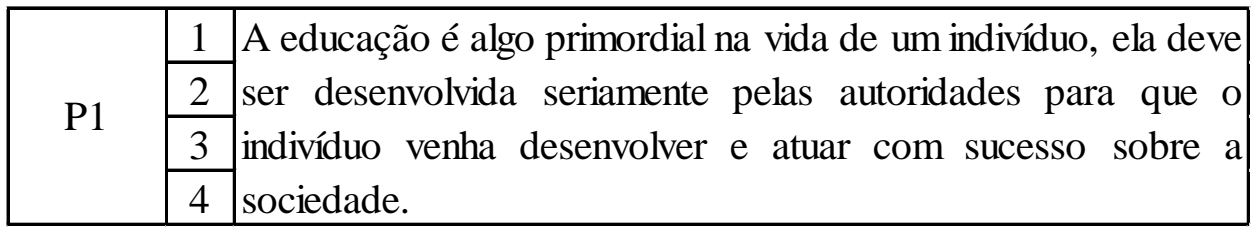

Redação 7. Educação e evolução. Turma C1 (cf. Anexo 7, p.133).

A tese do texto em questão se desenvolve em função do elemento julgado, o objetivo final do autor é mostrar o que se deve fazer para que o indivíduo venha desenvolver e atuar com sucesso sobre a sociedade (linhas 2 a 4). $\mathrm{O}$ comportamento do indivíduo, ancorado no Julgamento, é vinculado ao sucesso que poderá obter em suas relações sociais, há uma questão moral envolvida no posicionamento do autor diante desta alegação.

O início da redação se dá com uma declaração de fácil aceitação por qualquer leitor: a educação é algo primordial na vida de um indivíduo (linha 1). Quando o escritor decide se posicionar positivamente e explicitamente a favor da educação, está deixando clara sua orientação temática, ainda assim, para ampliar sua afirmativa, adota a Gradação de intensidade como um elemento potencializador do seu posicionamento com o uso do atributo primordial (linha 1).

O posicionamento crítico está centrado na importância da educação e, a partir daí, o autor recorre ao Julgamento para avaliar a maneira como se devem comportar as autoridades que desenvolvem a educação dos indivíduos, quando explica que ela deve ser desenvolvida seriamente pelas autoridades (linhas 2 e 3). O emprego do adjunto adverbial seriamente (linha 2), vinculado ao adjunto modal 
em deve ser (linhas 2 e 3) garante a conduta considerada adequada, pelo autor, para as autoridades.

A maneira como o autor se posiciona diante da proposta de redação irá esclarecer seu percurso argumentativo. É interessante observar, aqui, que a forma como o escritor elabora sua tese é ancorada em proposições que partem em defesa da educação de maneira a ser uma forma plena de desenvolvimento humano para que os indivíduos possam atuar com sucesso sobre a sociedade (linhas 3 e 4).

De maneira bastante objetiva, o autor fundamenta seus pontos de vista através de recursos avaliativos como o Julgamento e a Gradação. O parágrafo introdutório (P1) da Redação 7 nos indica o quanto alguns elementos da Avaliatividade podem funcionar como pilares argumentativos estruturando o texto de maneira bastante sólida. Neste exemplo, vimos o quão forte é o Julgamento de estima social na construção da tese.

A seguir, na introdução da Redação 8, veremos o valor do Julgamento e da Apreciação como recursos que concedem força à argumentação por incompatibilidade (cf. capítulo 2, seção 2.4, p. 49), isto é, a argumentação que é fundamentada na demonstração de uma tese anterior (que pode ser considerada tese de adesão inicial) e na contrariedade dela com a tese principal.

\begin{tabular}{|c|c|c|}
\hline & & \multirow{7}{*}{$\begin{array}{l}\text { Escrever bem está relacionado diretamente com uma boa } \\
\text { leitura, pois habilita ao desenvolvimento de ideias com } \\
\text { coerência, utilizando regras da norma culta e com vocabulário } \\
\text { enriquecido. Em contrapartida pessoas que não tem o hábito da } \\
\text { leitura normalmente utilizarão de um linguajar mais pobre de } \\
\text { acordo com a língua falada, que via de regra, não faz uso de } \\
\text { todos os recursos da língua escrita. }\end{array}$} \\
\hline & & \\
\hline & & \\
\hline & & \\
\hline & & \\
\hline & & \\
\hline & & \\
\hline
\end{tabular}

Redação 8. Escrever bem é o produto da leitura. Turma B1 (cf. Anexo 8, p.134).

Para estabelecer a incompatibilidade entre seus enunciados, o autor usa recursos da Apreciação e da Gradação ao desenvolver suas ideias e, posteriormente, seleciona o item lexical Em contrapartida (linha 4) para pontuar a contradição de declarações e segue com mais recursos da Apreciação, da Gradação e do Julgamento como veremos adiante, na continuação da análise deste parágrafo. 
Durante a tese de adesão principal, o autor explica que a qualidade da escrita está vinculada à qualidade da leitura, e utiliza a Apreciação direta e explícita nos atributos bem (linha 1), boa (linha 1) e a Gradação associada à Apreciação em enriquecido (linha 4). Mas há, também, Apreciação no que diz respeito à performance dos indivíduos tendo em vista que a escrita, associada à leitura, habilita ao desenvolvimento de ideias com coerência (linhas 2 e 3). Dessa maneira, o desempenho dos indivíduos é melhor, é potencializado de acordo com a habilidade que tenham com a escrita.

O operador argumentativo em contrapartida (linha 4) nos indica o recurso de incompatibilidade que estrutura a segunda parte da tese, e a Apreciação negativa continua servindo como elemento potencializador do posicionamento do autor, acentuando contrastes, e de suas avaliações críticas quando situa nós, leitores, que as pessoas (...) utilizarão de um linguajar mais pobre de acordo com a língua falada, que via de regra, não faz uso de todos os recursos da língua escrita (linhas 4 a 7). Para o autor, a Apreciação estética do uso que essas pessoas fazem da língua é comprometida.

O uso da argumentação por incompatibilidade faz brotar elementos avaliativos de Apreciação positiva e negativa, também apontando uma polaridade argumentativa acentuada pelo contraste entre as alegações do autor. Vale observar que essa construção argumentativa só é possível em função dos recursos avaliativos selecionados.

Tomando por base a relação que existe entre o "potencial de significados" e o "potencial argumentativo”, é possível tecer um paralelo entre a abordagem de linguagem proposta pela Linguística Sistêmico-Funcional e o estudo da argumentação. Outras escolhas semânticas e lexicais aliadas a outras estratégias argumentativas resultariam em outras instanciações e análises. Portanto, o potencial argumentativo e o potencial de sentidos de um texto podem criar diferentes efeitos para o leitor. Logo, vemos que há uma relação entre o percurso argumentativo selecionado pelo aluno/autor, em função das estratégias que utilizará e o sistema de escolhas paradigmáticas, intencionais ou não, que o sujeito faz em meio a múltiplas oportunidades que tem a sua disposição.

Conforme ilustrado no parágrafo seguinte P1 da Redação 9 (A importância da escrita), que o autor aplica a Apreciação negativa e explícita para se posicionar 
a respeito da maneira como vê a escolaridade brasileira, suas opiniões e críticas se apresentam embasadas no argumento pragmático e na argumentação por analogia.

\begin{tabular}{|c|c|c|}
\hline & & \multirow{7}{*}{$\begin{array}{l}\text { A falta de incentivo aos estudos e de investimentos na } \\
\text { infraestrutura são algumas das causas de o Brasil ter um dos } \\
\text { piores níveis de escolaridade do mundo. Isso faz com que a } \\
\text { escrita perca sua importância e fique em segundo plano, no que } \\
\text { diz respeito à inclusão social. Além disso, há muitos exemplos } \\
\text { de pessoas no país que conseguem ascender socialmente sem } \\
\text { precisar da escrita. }\end{array}$} \\
\hline & & \\
\hline & & \\
\hline & 4 & \\
\hline & & \\
\hline & & \\
\hline & & \\
\hline
\end{tabular}

Redação 9. A importância da escrita. Turma A1 (cf. Anexo 9, p.135).

O parágrafo é dividido em três grandes enunciados:

(1) A falta de incentivo aos estudos e de investimentos na infraestrutura são algumas das causas de o Brasil ter um dos piores níveis de escolaridade do mundo (linhas 1 a 3).

(2) Isso faz com que a escrita perca sua importância e fique em segundo plano, no que diz respeito à inclusão social (linhas 3 a 5).

(3) Além disso, há muitos exemplos de pessoas no país que conseguem ascender socialmente sem precisar da escrita (linhas 5 a 7).

O enunciado (1) já demonstra a Apreciação negativa que o autor faz da educação no Brasil. Sua orientação argumentativa sugere que, para ele, o Brasil possui um dos piores índices de escolaridade do mundo. A critica repousa no elemento apreciado negativamente um dos piores níveis de escolaridade do mundo (linha 3).

Na segunda sentença Isso faz com que a escrita perca sua importância e fique em segundo plano, no que diz respeito à inclusão social (linhas 3 a 5), podemos observar que há o elemento Isso (linha 3) é responsável por retomar sua declaração anterior (A falta de incentivo (...) e de investimentos, linha 1), justificando a razão pela qual a escrita perca sua importância. A perda da importância e a posição de segundo plano atribuída a escrita é mais uma forma de fazer uso da Apreciação negativa para pontuar o aspecto crítico do texto. 
O trecho em questão sugere que a construção do posicionamento do autor e de sua orientação argumentativa se dá através do uso de sentenças avaliativas que apreciam negativamente a questão temática da redação.

O terceiro enunciado oferece ao leitor mais elementos da Apreciação que irão funcionar como pilares para a elaboração do potencial argumentativo do texto ao atuarem como recursos opinativos e críticos que são responsáveis pela construção do posicionamento do autor. Ao alegar que há muitos exemplos de pessoas no país que conseguem ascender socialmente sem precisar da escrita (linhas 5 a 7), ele situa a questão da ascensão social que é oriunda de outro espaço que não a escola. Para ele, há pessoas que conseguem ascender socialmente sem precisar da escrita (linhas 6 e 7) este é um dos exemplos que explicam a falta de investimento em educação. Neste fragmento há o Julgamento de estima social negativa indicando que, para o autor, esta não é a melhor escolha de ascensão social.

Além disso, a análise sugere que elementos da Gradação que funcionam para potencializar o aspecto crítico do texto quando estão associados a posicionamentos de Atitude, como no fragmento piores níveis de escolaridade do mundo (linha 3), no operador argumentativo Além disso (linha 5) e em muitos exemplos (linha 5). Todos esses itens lexicais graduados são responsáveis por potencializar o posicionamento do autor no texto, levando-nos a perceber o quão importantes são as afirmativas do autor, para ele.

O P1 da Redação 9 é permeado de críticas que constroem o posicionamento do autor e são facilmente identificadas através dos recursos da Avaliatividade. Com isso, podemos perceber que os recursos avaliativos servem para demonstrar a orientação argumentativa que um texto irá propor.

A seguir, no último parágrafo de análise desta seção, a Redação 10 da Turma E1, poderemos notar que os elementos da Atitude são somados à Gradação para que se possa identificar a maneira como o autor trilha seu caminho argumentativo a levar-nos a concordar com sua tese. Posicionar-se assertivamente e, ainda, fazendo uso da Gradação faz com que os leitores não tenham outra alternativa que não a concordar com a tese do autor de que dominar a escrita e ler é muito importante para aquele que pretende ser incluído socialmente.

Neste parágrafo examinaremos que a Apreciação e o Julgamento, conforme citado anteriormente no início desta seção, possuem áreas de 
aproximação. A Apreciação é utilizada para que possamos avaliar questões de valor indicando qualidades estéticas, desta forma, quando apreciamos atribuímos um determinado valor estético ao que é apreciado. Já o Julgamento trata de qualidades éticas, indicando determinado valor ao comportamento humano. Existem algumas áreas nebulosas em relação ao Sistema da Atitude, principalmente, como veremos a seguir, no que diz respeito a questões estéticas vinculadas ao comportamento humano, que se aproximam do conceito de Julgamento de estima social, mas não deixam de ser Apreciações estéticas. Em algumas situações (Vian Jr., 2010, p.121) já se observou que o léxico aplicado ao Julgamento pode ser o mesmo utilizado para a Apreciação, é o que veremos a seguir na Redação 10.

\begin{tabular}{|c|c|c|}
\hline & 1 & \multirow{6}{*}{$\begin{array}{l}\text { Saber dominar a escrita de sua própria língua é algo de extrema } \\
\text { importância para qualquer indivíduo que convive em sociedade. } \\
\text { Saber ler e escrever é o passo mais importante para que a } \\
\text { pessoa seja, de fato, incluída na sociedade, afinal a leitura e a } \\
\text { escrita fazem parte de nosso cotidiano, assumindo grande papel } \\
\text { no convívio social. }\end{array}$} \\
\hline & 2 & \\
\hline & 3 & \\
\hline & 4 & \\
\hline & 5 & \\
\hline & & \\
\hline
\end{tabular}

Redação 10. Chave para o conhecimento. Turma E1 (cf. Anexo 10, p.136).

A primeira declaração feita pelo autor neste parágrafo é a de que Saber dominar a escrita de sua própria língua é algo de extrema importância para qualquer indivíduo que convive em sociedade (linhas 1 e 2). Nos atendo ao recurso da Atitude utilizado, percebemos que dominar a escrita (linha 1) é uma Apreciação estética já que há um aspecto estético na sentença, contudo, quando constatamos que semanticamente há uma relação de importância para aquele que convive em sociedade, estamos tratando da questão do comportamento do indivíduo que o leva ao conceito de estima social, de pertencimento para aquele que convive em sociedade (linha 2). Portanto, trata-se, de fato, de um Julgamento de estima social quando a habilidade em questão perpassa a questão puramente estética para um aspecto da construção da identidade de um indivíduo.

A condução argumentativa do texto é exposta na primeira parte do parágrafo. A instanciação do Julgamento positivo constrói um posicionamento bastante autoral e orientado a defender a escrita como forma de inclusão social, respondendo, dessa maneira, à proposta de redação desta análise. 
No segundo enunciado do texto, há um reforço do posicionamento anterior, mais uma vez, permeado pelo Julgamento de estima social de que é importante saber ler e escrever para a inclusão social em Saber ler e escrever é o passo mais importante para que a pessoa seja, de fato, incluída na sociedade (linhas 3 e 4). A presença da Gradação, no atributo intensificado mais importante (linha 3) e de fato (linha 4), bem como na sentença anterior no elemento extrema importância (linhas 1 e 2), acentuam a maneira como o autor se posiciona no texto e ajuda a construir enunciados de maior força argumentativa.

A tese do autor se encerra depois da conclusão de que afinal a leitura e a escrita fazem parte de nosso cotidiano, assumindo grande papel no convívio social (linhas 4 a 6), não deixando qualquer dúvida quanto à orientação argumentativa do texto ou do posicionamento do autor que é favorável ao ensino da leitura e da escrita para a inclusão social. O enunciado em questão apresenta a leitura e a escrita como protagonistas do texto, e o autor deixa claro sua estima por estas práticas quando faz uso do Julgamento positivo associado, novamente, à Gradação no grupo nominal grande papel (linha 5), ao situar a importância da leitura e da escrita para o cotidiano dos indivíduos.

Com a análise dos cinco parágrafos apresentados nesta seção, observamos de que maneira o Julgamento e a Apreciação são instanciações do posicionamento dos autores e da elaboração argumentativa do texto. Através de recursos opinativos e críticos da Avaliatividade pudemos compreender como são ativadas as avaliações positivas ou negativas de um determinado enunciado. Portanto, proponho que quando há Julgamento e/ou Apreciação em um determinado enunciado, há o reconhecimento de um posicionamento mais autoral e um percurso argumentativo mais bem construído, ou seja, mais marcado.

A figura abaixo apresenta uma síntese da análise dos recursos avaliativos desta seção para a construção do potencial argumentativo e do posicionamento autoral, isto é, quando o autor se apropria de recursos do Julgamento e/ou da Apreciação para favorecer seus pontos de vista nos enunciados, amplia o potencial argumentativo do texto e inscreve de maneira mais forte seu posicionamento autoral. 
JULGAMENTO E/OU APRECIAÇÃO

POTENCIAL ARGUMENTATIVO

POSICIONAMENTO AUTORAL

Figura 17 - Recursos opinativos e críticos na construção do percurso argumentativo e do posicionamento do autor

Será discutida a seguir, na última seção desta análise, a maneira como os autores constroem seus posicionamentos selecionando recursos do Engajamento e de que maneira eles podem ser úteis no reforço do potencial argumentativo e na construção do posicionamento autoral.

\section{3 \\ O Engajamento - estratégias para a concessão de força ao posicionamento e à argumentação}

Com o objetivo de analisar a maneira como se constrói o posicionamento do aluno em textos dissertativo-argumentativos, assim como foi observado na Gradação como elemento potencializador do posicionamento autoral e da argumentação e no uso do Julgamento e a Apreciação atuando como recursos opinativos na construção do posicionamento autoral, analisaremos de que maneira a soma dos recursos da Atitude atuam junto ao Engajamento pode reforçar o posicionamento autoral e auxiliar na construção argumentativa do texto.

Conforme apresentado no capítulo 2, sabemos que o grau de interação entre autor e enunciado é denominado no Sistema da Avaliatividade como Engajamento e que linguisticamente, nos textos, pode ser demonstrado através da presença de outras vozes no discurso e na relação entre o autor e tais enunciados. É no Engajamento que identificamos as sutilezas e insinuações de posicionamento, sendo possível negociar tal posicionamento de maneira mais ou menos explícita.

O Engajamento pode variar de um extremo ao outro, de maneira mais implícita até a mais explícita. O procedimento dialógico, estabelecido através da presença de outras vozes, poderá trazer ao texto elementos que auxiliarão na construção argumentativa e o autor pode decidir se alinhar ou não com essas vozes tornando maior ou menor o seu comprometimento com o enunciado, 
acentuando ou suavizando seu posicionamento autoral como veremos nos textos a seguir.

Examinaremos outros cinco primeiros parágrafos de introdução de textos selecionados para esta análise. A introdução, como sabemos, é um momento no qual os autores geralmente esclarecem sua tese e, por isso, deve ser um espaço de maior posicionamento autoral. Discutiremos, a seguir, quais recursos de Engajamento (cf. capítulo 2, seção 2.2.2.) são os mais utilizados na construção do posicionamento autoral e quais conferem maior ou menor força argumentativa nas redações selecionadas.

O primeiro parágrafo da Redação 11 (Turma B1 - título: Inclusão Social) apresenta características muito significativas na representação dos elementos lexicogramaticais e semânticos fixadores do Julgamento, e poderemos perceber o quão esses usos podem ser eficazes para construir o posicionamento autoral e oferecer maior força argumentativa, quando associados ao recurso do Engajamento.

A tese defendida no parágrafo de introdução propõe que as pessoas não possuem oportunidade de terem um bom ensino e julgar essas pessoas por sua escolaridade, a fim de incluí-las na sociedade, não é justo.

\begin{tabular}{|c|c|l|l|}
\hline \multirow{3}{*}{ P1 } & 1 & Vivemos em uma sociedade, onde as pessoas são julgadas de \\
\cline { 2 - 2 } & 2 & acordo com sua escolaridade, onde pessoas que infelizmente, \\
\cline { 2 - 2 } & 3 & na maioria das vezes por causa da pobreza, não possuem \\
\cline { 2 - 2 } & 4 & oportunidade de ter um bom ensino ou não conseguem concluir \\
\cline { 2 - 2 } & 5 & os estudos como na maioria dos casos, seria justo usar a \\
\cline { 2 - 2 } & 6 & escolaridade como um método para a inclusão social? \\
\hline
\end{tabular}

Redação 11. Inclusão Social. Turma B1 (cf. Anexo 11, p.137).

O autor da Redação Inclusão Social inicia sua abordagem utilizando o argumento de regra de justiça (cf. capítulo 2, seção 2.4, p. 49) na sentença Vivemos em uma sociedade, onde as pessoas são julgadas de acordo com sua escolaridade (linhas 1 e 2) relacionando-a com seria justo usar a escolaridade como um método para a inclusão social? (linhas 5 e 6).

A afirmativa, nas linhas 1 e 2, parece atender as expectativas do leitor, alinhando-o ao autor através da redução dialógica na monoglossia. Conforme mencionado no capítulo 2 , nos textos do tipo dissertativo-argumentativo podemos 
ter alegações que partem do "senso comum”, que geralmente não são o tipo de estratégia mais recomendada para estes textos, ainda que os alunos reconheçam esta forma de argumentar.

A linguagem monoglóssica (cf. capítulo 2, seção 2.2.2, p. 36) é vista como uma afirmação simples de fácil aceitação, ainda que, conforme Martin e White (2005) exista uma distinção na maneira como a proposição é apresentada (Ponto pacífico ou Ponto questionável). Neste parágrafo (P1, Redação 11), a monoglossia se apresenta como Ponto pacífico, pois não há espaço para contrariedade de posições nem tampouco existe a necessidade de embasar a afirmativa em outros enunciados ou proposições que a suportem.

A argumentação do autor continua sendo tecida quando há a afirmação que essas pessoas por causa da pobreza, não possuem oportunidade de ter um bom ensino ou não conseguem concluir os estudos (linhas 3 a 5). O elemento fixador do Julgamento negativo, de estima social, está na ideia de que a culpa das pessoas não possuírem a oportunidade de se escolarizarem é da pobreza, desse modo, por causa da pobreza (linha 3), as pessoas não possuem oportunidade de ter um bom ensino (linhas 3 e 4), e essas pessoas são julgadas de acordo com a sua escolaridade (linhas 1 e 2).

No Engajamento através de uma alegação heteroglóssica, em não possuem oportunidade de ter um bom ensino (linhas 3 e 4) e em não conseguem concluir os estudos (linhas 4 e 5), há um reforço argumentativo, e, apresenta-se aqui, a voz do não. A argumentação pela regra de justiça (cf. capítulo 2, seção 2.4, p. 49) está no elemento semântico, fixador do Julgamento, de que não é justo as pessoas serem julgadas por algo que não tiveram a oportunidade de demonstrar, por fazerem parte de uma classe social menos favorecida, serem pobres, e não terem acesso ao bom (Apreciação positiva e explícita) ensino (linha 4). A informação recuperada é a de que o autor está julgando a injustiça cometida com os menos favorecidos, em função de aspectos semânticos e lexicais.

O autor responde a pergunta da proposta de Redação (cf. Anexo 16, p. 142) através da construção argumentativa e emprega o recurso do Engajamento, pela da contração dialógica, que restringe qualquer posição de desacordo ou rejeição de suas premissas, com o recurso retórico da pergunta no final do parágrafo: seria justo usar a escolaridade como um método para a inclusão social? (linhas 5 e 6 ). 
Como apresentado no capítulo 2, o Engajamento através da contração dialógica oferece ao texto uma redução de posicionamentos contrários ao do autor, e a pergunta retórica no recurso de expectativa confirmada reduz a possibilidade de discordância, portanto, ainda que seja uma pergunta, não cabe ao leitor outra resposta a não ser concordar com o autor.

Dessa maneira, o escritor deixa claro, através de seu percurso argumentativo fortemente permeado de Julgamento, que não é justo usar a escolaridade como ferramenta de inclusão social, identificando um posicionamento bastante autoral. E, ainda que questione o leitor em seria justo usar a escolaridade como um método para a inclusão social? (linhas 5 e 6), tal estratégia funciona para trazer a concordância do leitor com sua tese. Diante das injustiças retratadas anteriormente, na contração e na expansão dialógica, não há a oportunidade de negociação da resposta (sim, é uma injustiça julgar as pessoas de pouca escolaridade e não incluí-las socialmente!), tendo em vista que já deixou claro o quão injusto seria utilizar a escolaridade como ferramenta para incluir socialmente um sujeito.

O Engajamento do autor com suas declarações está fortemente posicionado no Ponto pacífico (cf. capítulo 2, seção 2.2.2, p. 37), como se todos nós já soubéssemos que vivemos em uma sociedade com determinadas características reconhecidas por todos, e é interessante observar que o ápice de seu posicionamento no texto está no uso do termo infelizmente (linha 2).

É importante ressaltar que o uso adjunto adverbial de forte posicionamento autoral infelizmente (linha 2), embora trate de um aspecto intrínseco ao ser humano (felicidade/infelicidade), não é utilizado neste contexto como um elemento de Afeto já que não trata, neste caso, da infelicidade do autor mas sim do que é, para ele, inadequado, por isso, está mais próximo da questão da moralidade do que de um sentimento. Para o autor, o termo infelizmente retrata o que é inapropriado, apontando para um desajuste entre uma declaração - pessoas são julgadas de acordo com sua escolaridade (linhas 1 e 2) - e outra - não possuem oportunidade de ter um bom ensino (linhas 3 e 4). Há concessão de força ao Engajamento através deste Julgamento, tornando o posicionamento mais autoral.

O parágrafo analisado da Redação 11 (Turma B1 - título: Inclusão Social) ilustra características muito significativas na representação dos recursos da 
Avaliatividade, demonstrando que sua presença pode oferecer maior força ao potencial argumentativo e à construção do posicionamento autoral. O Engajamento do autor é reforçado através do Julgamento negativo de estima social e da Apreciação positiva.

A estratégia argumentativa selecionada pelo autor consistiu em apresentar a contração dialógica, posteriormente uma expansão dialógica de vozes concordantes e encerrar a argumentação em uma pergunta retórica em contração dialógica por negação. Aliar o Julgamento e a Apreciação aos recursos do Engajamento ofereceu ao leitor um texto mais fortemente posicionado.

A primeira seção deste capítulo analisou o apoio da Gradação aliada a outro elemento da Avaliatividade para construir um posicionamento mais autoral. Investigamos, também, como o posicionamento autoral pode ser enfatizado, ampliado ou amenizado no texto através de recursos da Avaliatividade. Portanto, quando o autor pretende se posicionar mais assertivamente potencializa seus pontos de vista com o uso de elementos lexicogramaticais e semânticos que nos levam a perceber o quão mais forte podem ser seus pareceres diante de uma avaliação. No fragmento a seguir, temos outro parágrafo de introdução em que o autor aplica recursos da Avaliatividade para atribuir mais força ao seu posicionamento e à sua argumentação.

O Engajamento na Redação 12, O valor atemporal do ensino sistemático, é estabelecido através da presença de outras vozes, com as quais o autor decide por não se alinhar, tornando ainda maior o seu comprometimento com suas próprias declarações e construções argumentativas, acentuando o posicionamento autoral.

\begin{tabular}{|c|c|c|}
\hline & 1 & \multirow{10}{*}{$\begin{array}{l}\text { Ultimamente, tem-se debatido muito a forma como a Língua } \\
\text { Portuguesa é ensinada em escolas. Alguns criticam até a } \\
\text { obrigatoriedade de seu aprendizado sistemático. Esses } \\
\text { opositores dizem que com a evolução da informática, qualquer } \\
\text { pessoa consegue aprender a usar a língua sozinha e, } \\
\text { principalmente, a seu modo. Entretanto, por mais que as } \\
\text { transformações digitais levantem questionamentos sobre o } \\
\text { ensino sistemático, a Língua Portuguesa deve continuar a ser } \\
\text { ensinada em escolas e instituições acadêmicas, visto que, a } \\
\text { mesma é essencial no processo de inclusão social. }\end{array}$} \\
\hline & 2 & \\
\hline & 3 & \\
\hline & 4 & \\
\hline & 5 & \\
\hline & 6 & \\
\hline & & \\
\hline & & \\
\hline & & \\
\hline & & \\
\hline
\end{tabular}

Redação 12. O valor atemporal do ensino sistemático. Turma E1 (cf. Anexo 12, p.138). 
O autor inicia seu texto com uma declaração de fácil assunção ao informar que Ultimamente, tem-se debatido muito a forma como a Língua Portuguesa é ensinada em escolas (linhas 1 e 2), a informação oferecida no texto parte de vozes que tem debatido o ensino da língua portuguesa. Desse modo, há o Engajamento em expansão dialógica, reconhecendo uma das muitas vozes possíveis (que debatem a forma como a língua portuguesa é ensinada), através do recurso de atribuição, que reconhece outros pontos de vista, mas assume um caráter de mínima responsabilidade sobre as alegações, iniciado pelo adjunto modal em ultimamente (linha 1).

Posteriormente a essa declaração, através do argumento de retorsão iniciado pelo operador argumentativo entretanto (linha 6), constitui-se a contradição dos argumentos do interlocutor e outras pessoas do discurso, personagens que oferecem ao texto a expansão dialógica de vozes discordantes que criticam até a obrigatoriedade de seu aprendizado sistemático (linhas 2 e 3), apontando um Engajamento por atribuição no recurso de reconhecimento, fortemente dialógico e intertextual, uma vez que o enunciado é apresentado como uma das muitas alternativas possíveis sobre o tema.

Ao escolher o adjunto adverbial até (linha 2), o autor faz uso da Gradação para já começar a identificar seu posicionamento contrário diante desta assertiva. Existem vozes que debatem a maneira como a Língua Portuguesa é ensinada nas escolas e há quem critique até a obrigatoriedade de seu aprendizado sistemático. Quando o autor emprega o elemento da Gradação, demonstra que há um despropósito em questionar a obrigatoriedade de seu aprendizado sistemático (linha 3) como se devesse ser óbvia a obrigatoriedade de aprender sistematicamente.

O autor da Redação 12 continua a utilizar a expansão dialógica no Engajamento por atribuição quando reconhece explicitamente os informantes do texto caracterizando-os como opositores (linha 4), demonstrando que há vozes divergentes e expressas que trazem posicionamentos discordantes. Para ele, opositores dizem que com a evolução da informática, qualquer pessoa consegue aprender a usar a língua sozinha e, principalmente, a seu modo (linhas 4 a 6). Com a escolha de opositores e escritor demonstra, claramente, o posicionamento autoral e o Engajamento explícito com o que se pretende declarar e estabelecer 
como caminho argumentativo. As vozes que emergem no texto estão caracterizadas como oponentes, concorrentes ao que se planeja comprovar.

É importante observar que antes de trazer a sua tese de que a Língua Portuguesa deve continuar a ser ensinada em escolas e instituições acadêmicas, visto que, a mesma é essencial no processo de inclusão social (linhas 8 a 10), o autor indica a presença de uma voz contrária que vai tornando-se mais reconhecida ao longo de seu percurso argumentativo: tem-se debatido (linha 1), alguns criticam (linha 2), Esses opositores dizem (linhas 3 e 4). O Engajamento, nesses três casos, se dá através da expansão dialógica, que prevê o reconhecimento de alternativas e vozes contrárias à do autor, no recurso de atribuição, que reconhece a proposição pela voz de um participante externo. Tratase de uma estratégia bastante viável para construir o percurso argumentativo do texto e apresentar a tese, neste caso, de que embora a tecnologia tenha mudado o cenário educacional, a língua portuguesa deve continuar a ser ensinada em escolas e instituições acadêmicas.

Ao fazer uso do grupo nominal qualquer pessoa (linhas 4 e 5), o elemento avaliativo qualquer sugere Gradação ao incluir na mesma categoria todas as pessoas, qualquer pessoa, sem considerar as peculiaridades no aprendizado de cada indivíduo. Tal estratégia confere à argumentação maior força, pois invalida a voz dos opositores do discurso que dizem que com a evolução da informática, qualquer pessoa consegue aprender a usar a língua sozinha (linhas 4 e 5). Com esta escolha, a generalização torna inválido o ponto de vista heteroglóssico e legitima o posicionamento do autor.

Em seguida, e ainda reforçando o compromisso do autor com suas afirmações, há o operador argumentativo adversativo entretanto (linha 6) que oferece uma ideia de contraste entre as vozes do texto - a do autor e a dos opositores (linha 4). O escritor constrói um ponto de contraste argumentativo e demonstra que é falha e inverossímil a voz dos opositores, atribuindo ao seu posicionamento monoglóssico a conclusão a que se deve chegar de que a Língua Portuguesa deve continuar a ser ensinada em escolas e instituições acadêmicas (linhas 6 a 9).

O autor ainda investe no Julgamento de estima social, explícito e positivo, quando em contração dialógica por pronunciamento afirma que a língua portuguesa é essencial no processo de inclusão social (linha 10). Aqui, ao dizer 
que a língua portuguesa é essencial, o autor considera os princípios morais da necessidade da língua portuguesa para a inclusão social, e não apenas o seu aspecto estético e performático, como seria o caso da Apreciação da língua como um elemento belo ou harmonioso.

Para ampliar seu posicionamento autoral e reforçar a argumentação ainda há o elemento da Gradação de intensidade essencial (linha 10), que acentua a importância da língua portuguesa no processo de inclusão dos indivíduos.

Como vimos na análise do processo exige , na Redação 2 da Turma A1 (cf. seção 4.1, p. 76), verificamos que essa escolha representa um eixo da Gradação quando comparado a outros termos (necessita e precisa). Também o atributo essencial (linha 10), propõe o quão engajado e posicionado está o autor com suas declarações, pois ao decidir fazer uso do item em questão oferece ainda mais força à Gradação.

Se fôssemos atribuir extremos para o atributo essencial, mantendo sua definição em termos sinônimos teríamos os seguintes sentidos para a língua portuguesa:

(1) é essencial no processo de inclusão social (Redação 12, Turma E1, linha 10).

(2) é importante no processo de inclusão social.

(3) é relevante no processo de inclusão social.

Reparamos que há maior força argumentativa no exemplo (1) é essencial no processo de inclusão social. E, por outro lado, menor força no exemplo (3), no termo relevante.

Ao associar a Gradação no item lexical essencial ao recurso do Julgamento quando explica que a língua portuguesa é essencial no processo de inclusão social (linha 10) o autor recorre, mais uma vez, à Avaliatividade para oferecer maior força ao seu enunciado monoglóssico. Cabe ressaltar que há uma sobreposição ao recurso da Apreciação ao recurso do Julgamento, já que existe toda uma interpretação semântica deste Julgamento, uma vez que onde se lê a língua portuguesa trata-se do comportamento dado pelo ensino da língua, um aspecto comportamental que envolve pessoas que ensinam a língua portuguesa. 
Quando o escritor informa que a língua portuguesa é essencial no processo de inclusão social, o enunciado monoglóssico, mais uma vez, é reforçado pelos recursos da Avaliatividade, portanto, ainda que outras vozes tenham debatido (linha 1), alguns criticam (linha 2) e opositores dizem (linha 4), o autor acredita que a língua portuguesa é essencial no processo de inclusão social (linha 10), reforçando seu posicionamento autoral, sua argumentação e, além disso, respondendo a questão temática da proposta de redação. Isso sugere que a monoglossia oferece ao Engajamento do aluno o percurso de sentido que deseja estabelecer, já que restringe o posicionamento dialógico a uma só voz, a sua, contrária a todas as demais anteriormente apresentadas.

$\mathrm{Na}$ análise da introdução da Redação 12 observamos que a estratégia do aluno para tornar seu posicionamento mais autoral foi aliar o recurso do Engajamento aos outros elementos da Avaliatividade, o Julgamento e a Gradação. A seguir, transcrevo outra introdução, a Redação 13, da Turma C1, com a intenção de entender como é construído o posicionamento do autor na construção argumentativa e de que maneira os recursos do Engajamento podem ser auxiliar na ampliação ou redução da força argumentativa do texto.

No P1 da Redação 13, a elaboração da tese é baseada na construção de um posicionamento fundamentalmente monológico que reduz a viabilidade de outras vozes emergirem no texto, e em afirmações como Ponto pacífico, nada questionáveis. Também perceberemos que, permeando a monoglossia predominante do parágrafo, há um enunciado heteroglóssico que abre espaço para a negociação de sentidos como um convite ao leitor a concordar com sua tese.

\begin{tabular}{|c|c|c|}
\hline \multirow{7}{*}{ P1 } & & \multirow{7}{*}{$\begin{array}{l}\text { A importância de se desenvolver a capacidade de escrita é } \\
\text { cada vez mais visível na sociedade contemporânea. Para } \\
\text { estudar em uma instituição de ensino superior, por exemplo, é } \\
\text { exigida grande habilidade de interpretar e produzir textos. A } \\
\text { escrita vem se consolidando em um mundo onde é preciso não } \\
\text { apenas saber ler, mas também ter ideias próprias e apresentá- } \\
\text { las em forma de texto escrito. }\end{array}$} \\
\hline & & \\
\hline & & \\
\hline & 4 & \\
\hline & & \\
\hline & & \\
\hline & & \\
\hline
\end{tabular}

Redação 13. Os reflexos positivos da capacidade de escrita. Turma C1 (cf. Anexo 13, p.139). 
Para auxiliar esta análise, cada enunciado do parágrafo de introdução da Redação 13 foi dividido em uma sentença, sendo (1), (2) e (3) que veremos, respectivamente, a seguir.

No parágrafo P1, o aluno pretende manifestar seu posicionamento sobre a importância de escrever no mundo moderno, e usa a monoglossia ao empregar duas sentenças afirmativas e pontuais em que há a redução ou eliminação de outras vozes de maneira que as alegações repousam no que White (2004) considera Ponto pacífico, isto é, algo aceito como verdadeiro. Com a monoglossia vemos que aparentemente o autor não deseja negociar:

A importância de se desenvolver a capacidade de escrita é cada vez mais visível na sociedade contemporânea. (linhas 1 e 2)

Para estudar em uma instituição de ensino superior, por exemplo, é exigida grande habilidade de interpretar e produzir textos. (linhas 2 a 4 )

A análise da sentença (1) sugere que, para o autor, é importante que um indivíduo desenvolva a habilidade escrita. O enunciado é simples e claro, e carrega, em si, um elemento que indica seu posicionamento acerca dessa importância. Ao tratar da capacidade da escrita (linha 1), o autor está avaliando a competência dos indivíduos no que concerne a uma habilidade para a inclusão social, por isso, perceberemos que há um Julgamento de estima social.

A declaração no argumento de definição pela normalidade (cf. capítulo 2, seção 2.4, p. 49) de que A importância de se desenvolver a capacidade de escrita é cada vez mais visível na sociedade contemporânea (linhas 1 e 2), esclarece a orientação argumentativa do posicionamento do autor e há uma avaliação sobre as suas afirmações nos itens lexicais de Julgamento quando indica que a importância (...) é cada vez mais visível (linhas 1 e 2), neste contexto, o autor julga que há uma importância em desenvolver a capacidade da escrita.

Outro recurso da Avaliatividade neste enunciado é a Gradação na expressão cada vez mais (linha 2), nos indicando que, para o autor, a importância da nossa sociedade desenvolver a capacidade da escrita já era visível e está, agora, cada vez mais aparente. Aqui vimos que a Gradação amplia o sentido criado pelo 
Julgamento de estima social, oferecendo maior força à construção do posicionamento do autor.

Na continuação, observando a sentença (2), o escritor seleciona uma estratégia argumentativa de exemplificação ao ilustrar que Para estudar em uma instituição de ensino superior, por exemplo, é exigida grande habilidade de interpretar e produzir textos (linhas 2 a 4). Quando analisamos o posicionamento dialógico deste enunciado, constatamos que o mesmo aspecto se repete, há monoglossia com a intenção de eliminar ou tornar implícita qualquer negociação de sentidos. Não há outra voz, não há espaço para negociação, não há outras afirmações possíveis, há uma alegação considerada Ponto pacífico, assim como vimos na sentença (1).

Nota-se, também, o Julgamento de estima social, do mesmo modo como foi apresentado na sentença (1), provoca uma avaliação da performance do indivíduo ao produzir e interpretar textos. Isto é, para que se possa alcançar determinado objetivo (como estudar em uma instituição de ensino superior) é exigida grande habilidade de interpretar e produzir textos. Em foco, aqui, está o comportamento humano, são avaliações que podem levar o indivíduo a ser elevado ou rebaixado na estima de sua comunidade.

Há a Gradação de intensidade e reforço, respectivamente, nos itens lexicais exigida e grande (linha 4). O autor nos informa que, para estar na universidade, é preciso saber interpretar e escrever textos, e acentua essa importância de possuir a habilidade de interpretar e produzir textos (linha 4) explicando que não é necessário, apenas, saber interpretá-los e produzi-los, mas que isso é uma exigência, e, além disso, não basta ter habilidade, ela precisa ser grande.

Nas duas primeiras sentenças percebemos que a monoglossia reduziu a possibilidade de negociação de sentidos, as declarações repousaram no Ponto pacífico, e se constituíram como teses de adesão inicial, de fácil aceitação, que levam o leitor a concordar com o que está sendo proposto. Aliado ao Engajamento fundamentado no posicionamento monoglóssico foram associados outros recursos da Avaliatividade, como o Julgamento reforçado pela Gradação. Assim, a tessitura da introdução sofre um rompimento com a sentença (3), que abre espaço para heteroglossia, como veremos a seguir.

O terceiro enunciado do primeiro parágrafo da Redação 13 apresenta o posicionamento heteroglóssico, pois a manifestação da contra expectativa em não 
apenas saber ler, mas (linhas 5 e 6) indica ao menos duas vozes, a do sim e a da exceção, mostrando o desejo de negociar significados e valores.

A escrita vem se consolidando em um mundo onde é preciso não apenas saber ler, mas também ter ideias próprias e apresentá-las em forma de texto escrito. (linhas 4 a 7)

A sentença (3) A escrita vem se consolidando em um mundo onde é preciso não apenas saber ler, mas também ter ideias próprias e apresentá-las em forma de texto escrito (linhas 4 a 7) apresenta a mesma orientação argumentativa em forma de declaração, entretanto, o enunciado não é apenas afirmativo, há a intenção de negociar sentidos e valores expressos nesta declaração já que há uma quebra na perspectiva afirmativa reforçada pela Gradação em não apenas (...) mas também (linhas 5 e 6).

Para o autor, há uma relação bem encadeada e lógica entre escrita, interpretação de texto, leitura e ideias próprias, que poderíamos chamar de “conteúdo”. O uso da Gradação, neste período (P1, Redação 13, Turma C1, linhas 4 a 7), demonstra a importância que o autor dá para a construção de ideias. Para ele, ter ideias próprias é ainda mais importante do que ler, apenas.

Ao compararmos a análise do parágrafo introdutório da Redação 13 com a Redação 12 (anterior), observamos que o escritor aliou elementos da Avaliatividade que funcionaram como recursos potencializadores de seu posicionamento e da argumentação no texto. Percebemos que trazer outros pontos de vista ao texto e estruturar a argumentação no contraste de vozes pode ser uma estratégia corajosa, ao potencializar as alegações do autor através de mais elementos avaliativos, como foi feito no P1 da Redação 12. Notamos, também, que estruturar a argumentação em teses de Ponto pacífico para, depois, oferecer outras vozes ao texto, que apoiam ou sustentam a alegação principal, pode oferecer ao texto um posicionamento bastante autoral, como vimos no P1 da Redação 13.

A seguir, serão apresentadas estratégias utilizadas pelo autor da Redação 14 na construção argumentativa de seu texto, e de que maneira os recursos do Engajamento podem auxiliar na ampliação ou redução do potencial argumentativo do texto. 
O Parágrafo 1 da Redação 14 apresenta dois momentos distintos de Engajamento, um monoglóssico de Ponto pacífico, baseado em uma afirmação simples que é potencializada pelo Julgamento de estima social, e um heteroglóssico baseado na expansão dialógica de evidências, em que há a interpretação de indícios, associado à Apreciação. Vejamos abaixo cada um dos momentos.

\begin{tabular}{|c|c|l|l|}
\hline \multirow{3}{*}{ P1 } & 1 & A escrita é um material de grande importância para o \\
\cline { 2 - 3 } & 2 & aprendizado de um ser humano. Como é observado, a escrita é \\
\cline { 2 - 3 } & 3 & decorrência de uma boa leitura, que por sua vez, admite um \\
\cline { 2 - 3 } & 4 & conhecimento amplo sobre diversos assuntos. \\
\hline
\end{tabular}

Redação 14. Inclusão e escrita. Turma D1 (cf. Anexo 14, p.140).

Nas linhas 1 e 2 o autor faz uma declaração de que a escrita é um material de grande importância para o aprendizado de um ser humano (linhas 1 e 2), colocando a prática da escrita como um instrumento, uma ferramenta de grande importância para o aprendizado. Na argumentação, tal estratégia pode ser considerada na elaboração de uma tese de adesão inicial, que parte de uma declaração de simples aceitação por parte do leitor. A escolha de criar uma tese de fácil consenso faz com que o autor conquiste o leitor de maneira que se crie um movimento de concordância, que irá conduzi-lo até a tese principal.

Há o Engajamento monoglóssico, que não indica nenhuma voz externa ou espaço para negociação de sentidos em a escrita é um material de grande importância para o aprendizado de um ser humano (linhas 1 e 2), reforçado pelo Julgamento de estima social de que escrever é importante para o aprendizado do ser humano. Entendo que há aqui uma avaliação performática do aprendizado dos indivíduos, e por isso o Julgamento de estima social. O uso da Gradação no léxico grande (linha 1), amplia o posicionamento do autor e nos permite assumir que para ele a escrita é mais do que importante.

O segundo momento do parágrafo de introdução da Redação 14 está centrado na presença de outras vozes que indicam a expansão dialógica por evidências em Como é observado (linha 2), apontando um posicionamento heteroglóssico associado ao recurso da Apreciação em boa leitura (linha 3) e conhecimento amplo (linha 4). 
O autor sai da afirmativa monoglóssica do enunciado anterior A escrita é um material de grande importância para o aprendizado de um ser humano (linhas 1 e 2), para um enunciado fortemente heteroglóssico de expansão dialógica no recurso de atribuição por reconhecimento em Como é observado, a escrita é decorrência de uma boa leitura, que por sua vez, admite um conhecimento amplo sobre diversos assuntos (linhas 2 a 4), assumindo e até de certa forma ratificando o enunciado. Tal estratégia oferece à argumentação maior força, pois sai do enunciado afirmativo e de uma só voz para um enunciado heteroglóssico de vozes concordantes quando o autor convida o leitor a perceber seu ponto de vista com o uso do item como é observado (linha 2).

A cada sentença há um novo ponto de vista, trazendo ao texto certa progressão temática. A instanciação dos recursos da Avaliatividade, neste parágrafo, feita de maneira consciente ou não, constrói um percurso argumentativo orientado para convidar o leitor a concordar com o que está sendo afirmado quando sai de uma declaração em contração dialógica por ratificação associada ao Julgamento de estima social em A escrita é um material de grande importância para o aprendizado de um ser humano (linhas 1 e 2), para uma declaração em expansão dialógica de vozes concordantes (associada à Apreciação) que contribuem para o reforço do posicionamento do autor em Como é observado, a escrita é decorrência de uma boa leitura, que por sua vez, admite um conhecimento amplo sobre diversos assuntos (linhas 2 a 4).

Com a análise do parágrafo de introdução da Redação 14 pudemos observar no Engajamento monoglóssico e heteroglóssico a importância dos recursos da Avaliatividade indicando o posicionamento autoral e a força argumentativa do texto.

O último texto analisado sob o ponto de vista do Engajamento reforça que a relação do autor com a presença de outras vozes no discurso pode ser potencializada se ele optar por fazer uso de mais recursos da Avaliatividade como o Julgamento e/ou a Apreciação.

Nos parágrafos anteriormente analisados, que a soma dos recursos da Avaliatividade atuam para reforçar o posicionamento autoral e potencializar a construção argumentativa do texto. A seguir, no Parágrafo 1 da Redação 15, que o grau de interação entre o autor e o enunciado pode indicar sutilezas e insinuações 
de pontos de vista, sendo possível negociar o posicionamento de maneira mais ou menos explícita com o auxílio dos recursos da Apreciação.

\begin{tabular}{|c|c|c|}
\hline & & \multirow{5}{*}{$\begin{array}{l}\text { Todas as pessoas tem um objetivo de vida e para consegui-lo } \\
\text { existem diversos caminhos. Esses Trajetos podem ser legais ou } \\
\text { ilegais, porém o único que só depende da pura vontade } \\
\text { Humana é o dos estudos. Para conseguir chegar até as suas } \\
\text { métas, pelo estudo, escrever bem é indispensável. }\end{array}$} \\
\hline & & \\
\hline & & \\
\hline & & \\
\hline & & \\
\hline
\end{tabular}

Redação 15. Objetivos pelo estudo. Turma A1 (cf. Anexo 15, p.141).

Partindo de um espaço fortemente monoglóssico que não permite a expressão de nenhuma outra voz no discurso, o autor explica que há vários caminhos para alcançar um determinado objetivo, e aplica a contração dialógica por ratificação para eliminar outros posicionamentos de vozes no enunciado, não reconhecendo proposições alternativas, consequentemente, não abre espaço para a negociação de pontos de vista e encerra o argumento de definição como Ponto pacífico.

A presença da Gradação em uma afirmativa fortemente monoglóssica potencializa a força do enunciado oferecendo maior posicionamento e fortalece a argumentação em todas (linha 1) e diversos (linha 2).

$\mathrm{Na}$ segunda sentença do parágrafo Esses trajetos podem ser legais ou ilegais, porem o único que só depende da pura vontade Humana é o dos estudos (linhas 2 a 4), o escritor continua em contração dialógica, sem abrir espaço para negociação, mas parte do Ponto pacífico para o Ponto questionável, incluindo em sua declaração uma informação que se insere no debate sobre os tipos de trajetos, legais ou ilegais, possíveis para alcançar um determinado objetivo. Tal estratégia funciona para antecipar o argumento que se apresenta, em seguida, de que o único [trajeto] que só depende da pura vontade Humana é o dos estudos (linhas 3 e 4).

O operador argumentativo porém (linha 3) auxilia no processo de contraste entre as afirmações de maneira a oferecer ao texto um maior posicionamento por parte do autor, esses trajetos podem ser legais ou ilegais, porém o único que só depende da pura vontade Humana é o dos estudos (linhas 3 e 4), ao fazer o uso do porém o autor já expõe seu caminho argumentativo.

Há Gradação de intensidade aumentando a força da declaração em único, só e pura (linha 3). Verificamos que a Gradação nestes elementos funciona como 
uma estratégia que reforça o Julgamento de estima social na avaliação da conduta do indivíduo em o único que só depende da pura vontade Humana é o dos estudos (linhas 3 e 4).

Embora o escritor permaneça oferecendo uma definição do que é importante para alcançar uma meta, o último enunciado do parágrafo abre um forte espaço dialógico, em expansão, quando há a inserção de uma pessoa com a qual se dialoga: Para conseguir chegar até as suas métas, pelo estudo, escrever bem é indispensável (linhas 4 e 5). O autor convida o interlocutor a inserir-se no enunciado ao fazer uso do pronome suas (linha 4), dessa maneira, trata-se de uma orientação para o leitor.

Para reforçar seu posicionamento no texto, além do uso das estratégias de Engajamento para ampliar ou reduzir o espaço dialógico no texto, o autor faz uso da Apreciação ao anunciar que para conseguir chegar até as suas métas, pelo estudo, escrever bem é indispensável (linhas 4 e 5). Isto é, a avaliação aqui é feita com foco no produto da performance do indivíduo escrever bem (linha 5), considera-se a questão estética que envolve o processo da escrita. O autor ainda utiliza a Gradação de reforço quando explica que escrever bem é indispensável (linha 5), potencializando a Apreciação através de um elemento que aumenta a importância da escrita.

Neste parágrafo, há indicação de que o movimento dialógico do texto pode ser reforçado de acordo com a maneira como são incluídos os recursos da Avaliatividade. De um enunciado fortemente monoglóssico de Ponto pacífico com o reforço (apenas) da Gradação o escritor passa para um enunciado de Ponto questionável, em que alia outros elementos avaliativos como o Julgamento e a Gradação, e termina em um enunciado em expansão dialógica, convidando o leitor para o texto. Esta estratégia nos permite compreender que quando há a possibilidade de gerar questionamento o autor habilmente associa outros elementos avaliativos o que irão auxiliar na argumentação e no reforço de seu posicionamento. E, ao contrário, quando percebe que não há chance de negociação, não faz tanto uso de recursos avaliativos que ofereçam um reforço persuasivo.

Diante da terceira seção de análise desta pesquisa analisamos como os autores fazem uso das estratégias de Engajamento para se inscreverem de maneira 
mais ou menos acintosa e quais são os recursos que dispõem para potencializar seus posicionamentos.

Quando há contração dialógica, isto é, a redução de pontos de vista e espaços de negociação no texto, os autores fazem uso de outros recursos avaliativos com a intenção de oferecer maior força argumentativa e ampliar o posicionamento autoral. Quando existe menos espaço para negociação, podem não ser necessários tantos recursos avaliativos para reforçar a argumentação já que a voz é uníssona e não há nenhuma contra alegação, dessa maneira, o percurso argumentativo pode ser menos longo e detalhado. Quando em contração dialógica a voz do autor é reforçada através de outros recursos avaliativos como o Julgamento, a Apreciação e a Gradação há uma potencialização do posicionamento autoral.

Da mesma maneira, quando há expansão dialógica de vozes discordantes há um esvaziamento, consciente ou não, dos elementos avaliativos que são responsáveis por diminuir a força de suas alegações, logo, os autores reduzem a força argumentativa de suas alegações afastando os recursos da Avaliatividade ou fazendo uso deles apenas para a suavização de suas alegações.

Já a expansão dialógica com vozes concordantes pode ser potencializada quando estão associados outros recursos avaliativos, auxiliando no reforço da argumentação e do posicionamento autoral, criando um caminho argumentativo mais detalhado e longo.

Vimos, também, que a pergunta que é aparentemente dialógica pode surgir em contração, fechando o espaço de negociação já que pode tender a uma resposta orientada pelo autor e que o Engajamento está fortemente relacionado aos meios pelos quais os autores adotam posições de valor determinadas socialmente. Sua afiliação ou distanciamento dessas proposições envolvem percepções positivas ou negativas de determinado elemento e a negociação de significados se dá a partir de elementos que partilhem valores da Avaliatividade.

O caráter avaliativo concede ao texto maior força argumentativa e maior posicionamento autoral. Gradação, Julgamento e Apreciação geram potenciais de significados que contribuem para que um texto possua proposições mais fortemente ancoradas no potencial argumentativo e no posicionamento autoral. 


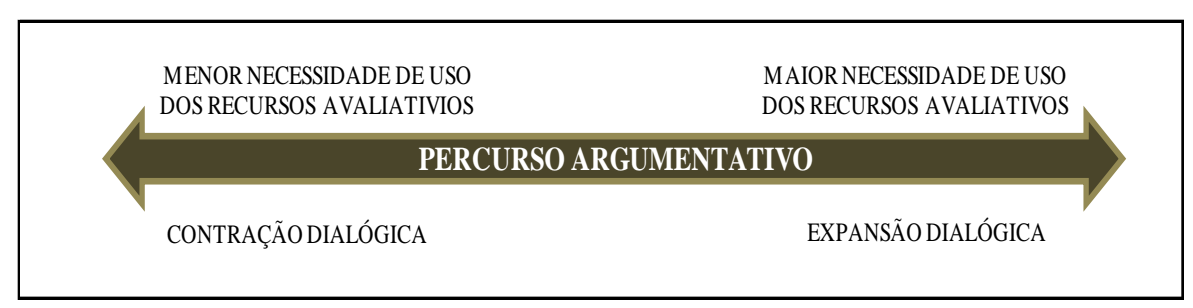

Figura 18 - Continuum de força na argumentação e no posicionamento autoral

Em um continuum, poderíamos considerar que a argumentação e o posicionamento autoral estão mais fortemente demonstrados no texto quando elementos da Avaliatividade estão atuando em conjunto. Ainda é importante observar que, quando há contração dialógica, a necessidade de potencializar os enunciados com outros recursos avaliativos não é tão grande quanto a importância de reforçar as sentenças em expansão dialógica associando outros recursos da Avaliatividade. Ou seja, quando há a presença de outras vozes no discurso, há, também, a necessidade de reforçar o posicionamento autoral e a força argumentativa do texto com o incremento de mais recursos avaliativos, como o Julgamento, a Gradação e a Apreciação.

\section{4 \\ Reflexões}

A análise das três categorias propostas nesta investigação sugeriu que o potencial argumentativo de um texto e o posicionamento do autor variam, em primeira instância, de acordo com a maneira como o autor escolhe e usa os recursos avaliativos.

De maneira geral, poderíamos considerar que a argumentação e o posicionamento autoral estão mais fortemente demonstrados no texto, quando elementos da Avaliatividade estão atuando em conjunto.

A primeira categoria analisada neste estudo demonstrou que a Gradação funciona como um elemento potencializador do posicionamento autoral, auxiliando no processo de argumentação quando está aliada a outro elemento da Avaliatividade, funcionando como um recurso de intensidade ou reforço, de acordo com cada estratégia utilizada.

Portanto, quando o autor pretende se posicionar de maneira mais incisiva, potencializa seus pontos de vista com o uso de elementos lexicogramaticais e 
semânticos que indicam mais acintosamente seus pareceres diante de uma avaliação.

A análise dos textos com base na categoria da Gradação permitiu observar que o posicionamento de caráter avaliativo se mostra como uma ferramenta fundamental na construção do potencial argumentativo, pois quando há a associação de um recurso da Atitude acentuado por um recurso da Gradação, o posicionamento e a força argumentativa do texto são potencializados. Portanto, da observação dos textos através desta categoria, notamos que o efeito da Avaliatividade serve aos objetivos do autor na construção de suas estratégias argumentativas, bem como o percurso argumentativo se constrói na medida em que instancia os recursos da Avaliatividade.

A abordagem Sistêmico-Funcional considera a linguagem como um sistema de construção de significados que partem de escolhas paradigmáticas e a segunda categoria analisada neste trabalho nos permitiu compreender que os elementos opinativos e críticos são instanciados pelos recursos do Subsistema do Julgamento e da Apreciação, que são, por sua vez, instanciados em função do potencial de significados de linguagem.

Esta categoria nos indicou que o percurso argumentativo de um texto se fundamenta, muitas vezes, através de elementos opinativos e críticos de que dispomos, e se constroem através das escolhas lexicogramaticais e semânticas que compõem recursos do Sistema da Avaliatividade. Tais recursos concedem força à argumentação e indicam o posicionamento do autor.

Vimos, ainda, que a Apreciação e o Julgamento, possuem áreas de aproximação e se caracterizam, em algumas situações nas quais partilham os mesmos elementos lexicogramaticais, em função de aspectos semânticos. Por isso, é importante que o autor se aproprie de recursos do Julgamento e/ou da Apreciação, de maneira consciente, para que possa favorecer seus pontos de vista nos enunciados oferecendo maior força ao potencial argumentativo do texto.

A terceira categoria de análise nos possibilitou compreender a maneira como os autores se constroem em seus textos. A análise dos dados ilustrou, por exemplo, que quando um autor seleciona o recurso de contração dialógica, minimiza a necessidade de potencializar os enunciados com outros recursos avaliativos, mas esta importância aumenta quando as sentenças estão em expansão dialógica. Neste caso, é necessário o incremento de outros recursos da 
Avaliatividade, como o Julgamento, a Gradação e a Apreciação, para potencializar a argumentação e o posicionamento do autor no texto.

O Engajamento está fortemente relacionado aos meios pelos quais os autores adotam posições de valor determinadas socialmente, quando se afiliam ou se distanciam de suas alegações envolvem, geralmente, percepções positivas ou negativas e negociam significados com o reforço dos recursos da Avaliatividade para que possam construir sua argumentação. Identificamos, desta maneira, as sutilezas e insinuações de posicionamento autoral e compreendemos como os autores negociam posicionamentos ao construir o percurso argumentativo de seus textos.

Os elementos lexicogramaticais e semânticos que constituem os recursos avaliativos concedem ao texto maior força argumentativa e maior posicionamento autoral. Gradação, Julgamento e Apreciação são potenciais de significados que contribuem para o potencial argumentativo de um texto e para o posicionamento do autor.

A análise dos textos investigados neste trabalho propôs que existe uma correspondência entre o "potencial de significados” de linguagem e o "potencial argumentativo” de um texto. Portanto, de acordo com este estudo é possível tecer um paralelo entre a abordagem de linguagem proposta pela Linguística SistêmicoFuncional e o estudo da argumentação.

As escolhas semânticas e lexicais feitas pelos autores aliadas a estratégias argumentativas resultam em potenciais de significados argumentativos que, de acordo com cada escolha paradigmática (de linguagem e de estratégia argumentativa), poderiam resultar em outras instanciações e análises.

O potencial argumentativo e o potencial de sentidos de um texto podem criar diferentes efeitos para o leitor. Isso pode indicar que se tais seleções forem feitas de maneira mais consciente e intencional, o autor pode construir um texto mais persuasivo através da seleção argumentativa e lexicogramatical que dispõe.

Tal constatação acentua a necessidade de agirmos para oferecer ao aluno/autor condições para que possa construir de maneira mais consciente as escolhas lexicais e semânticas de seus textos. Isso pode ser viável através da proposta de atuar, em sala de aula, da mesma maneira como se construíram os pressupostos teóricos deste trabalho, com o apoio da Avaliatividade e da LSF na prática docente. 
Os alunos que participaram desta pesquisa estudam o percurso argumentativo do texto dissertativo e são expostos a teorias de argumentação, e, dessa forma, fazem uso de estratégias argumentativas. Quando pensamos no percurso argumentativo, presumimos o ato de convencer ou persuadir o outro a concordar com o que julgamos como válido, e já estamos, neste caso, tratando de elementos da Avaliatividade, pois ao argumentar, avaliamos. Além disso, sabemos que essa realização só acontece por meio da linguagem, portanto, limitar a capacidade dos alunos em escolher conscientemente os efeitos de sentido que desejam criar pode significar uma limitação das habilidades que tais autores possuem para argumentar, levando-os a apenas reproduzir conhecimentos cristalizados através de modelos de argumentação preestabelecidos teoricamente. 


\title{
Considerações Finais
}

\author{
O prazer do texto é isto: o valor passado ao grau \\ suntuoso de significante. \\ Roland Barthes (2002, p.77)
}

Conforme vimos na introdução deste trabalho, escrever é uma prática que envolve valores intrínsecos ao autor, quando escrevemos também nos inscrevemos no texto, nos associamos a alguns ideais e manifestamos nossos pontos de vista na representação textual, com isso, materializamos nossos posicionamentos. Como professora, tenho a crença de que a escrita pode nos proporcionar a inclusão social, tão citada na proposta de redação que foi ofertada aos alunos, autores das redações analisadas aqui. É também através da escrita que podemos identificar a maneira como os autores querem ser vistos pela e na sociedade.

Este trabalho teve por objetivo investigar de que maneira é construído o posicionamento do autor em textos dissertativo-argumentativos produzidos por alunos do Ensino Médio. Para tanto, algumas perspectivas teóricas serviram para sustentar esta pesquisa. O aspecto semântico, contextual, funcional, semiótico e social da Linguística Sistêmico-Funcional, por ter interesse nos objetivos e razões pelas quais os indivíduos fazem uso da linguagem e por compreendê-la como um recurso estratégico e criador de sentidos que é oriundo da abordagem interpretativa e descritiva, nos permitiu identificar, por meio da linguagem, características dos indivíduos produtores de textos e seus posicionamentos de valor, já que é através dela que os indivíduos revelam seus valores, seus pensares, sua cultura e sua história. O Sistema da Avaliatividade ofereceu a esta pesquisa uma proposta de análise textual capaz de identificar a maneira como indivíduos adotam posicionamentos e valores e negociam significados, ou seja, a maneira como os indivíduos selecionam em seu repertório linguístico formas e estruturas que irão valorar e identificar seu posicionamento ideológico e seus julgamentos nos textos. 
A teoria de Argumentação possibilitou a compreensão da estrutura textual como um procedimento linguístico com o propósito de persuadir, por entender o texto como um espaço em que partilhamos valores, ideais e posicionamentos de acordo com os pontos de vista dos autores e, por essa razão, foi um recurso importante para investigar o movimento autoral dos alunos nos textos.

Três perguntas de pesquisa auxiliaram no desenvolvimento desta investigação que pretendeu investigar a construção do posicionamento do autor em textos dissertativo-argumentativos. São elas:

1. De que forma o posicionamento do autor é expresso nos parágrafos introdutórios dos seus textos?

2. De que maneira o uso dos recursos da Avaliatividade podem ser vistos como possíveis estratégias de argumentação?

3. Que potenciais de significados argumentativos podem ser criados através dos recursos da Avaliatividade?

Desta maneira, respondendo às perguntas de pesquisa que foram apresentadas neste estudo, vimos que o posicionamento do autor é expresso nos parágrafos introdutórios dos seus textos de maneira muito forte quando são utilizados os recursos da Avaliatividade para oferecer maior suporte e subsídios à argumentação. Os recursos da Avaliatividade podem ser observados nas categorias propostas nesta análise: (1) a Gradação como elemento potencializador do posicionamento do autor e da argumentação; (2) o Julgamento e a Apreciação atuando como recursos opinativos na construção do posicionamento autoral; e (3) o Engajamento como recurso de concessão de força ao posicionamento e à argumentação.

Tais categorias de análise revelaram que a Gradação funciona como um recurso potencializador do posicionamento do autor e da argumentação, desta maneira o posicionamento autoral pode ser enfatizado, ampliado ou amenizado no texto através de recursos da Gradação associados à outra marca da Avaliatividade. Ou seja, quando o autor pretende se posicionar mais assertivamente, potencializa seus pontos de vista com o uso de elementos lexicogramaticais e semânticos que nos levarão a perceber o quão mais forte podem ser seus pareceres diante de uma avaliação. 
Reconhecemos através da segunda categoria proposta, os elementos lexicogramaticais e semânticos de Julgamento e Apreciação (inclusive concomitantemente) como recursos opinativos na construção do posicionamento autoral, ou seja, a argumentação e o posicionamento autoral estão mais fortemente demonstrados no texto, quando elementos da Avaliatividade estão atuando em conjunto.

E, por último, os resultados desta análise nos indicam que os recursos de Engajamento concedem maior força ao posicionamento e à argumentação, pois estão intrinsecamente relacionados aos meios pelos quais os autores adotam posições de valor determinadas socialmente. A afiliação ou distanciamento dessas proposições envolvem percepções positivas ou negativas de determinado elemento e a negociação de significados se dá a partir de recursos de Engajamento, principalmente no que diz respeito a contração ou expansão dialógica.

Ainda é importante observar que, quando há contração dialógica, a necessidade de potencializar os enunciados com outros recursos avaliativos não é tão grande quanto a importância de reforçar as sentenças em expansão dialógica associando outros recursos da Avaliatividade. Ou seja, quando há a presença de outras vozes no discurso, é, também, conveniente reforçar o posicionamento autoral e a força argumentativa do texto com o incremento de mais recursos avaliativos, como o Julgamento, a Gradação e a Apreciação.

Considerando a linguagem como um sistema de construção de significados, a maneira como os falantes fazem uso dela em contextos reais de produção requer a concepção de que há um sistema de escolhas paradigmáticas, intencionais ou não, que o sujeito faz em meio a múltiplas oportunidades que o sistema oferece. São inúmeros os potenciais de significados criados pela e através da linguagem. O sistema linguístico e o sistema social compreendem todo o potencial de significado que será instanciado pelo texto.

A terceira pergunta deste estudo procurava entender que potenciais de significados argumentativos poderiam ser criados através dos recursos da Avaliatividade. Desta análise surgiu a proposta de compreender a relação entre potenciais de significados argumentativos e o potencial de significados de linguagem. 
De acordo com os resultados desta investigação, proponho que são inúmeros os potenciais de significados argumentativos que podem ser criados através dos recursos da Avaliatividade. E a contribuição teórica desta pesquisa sugere que há uma relação entre "potencial de significados de linguagem” e o “potencial de significados argumentativos” de um texto, que se inscreve em um “potencial de posicionamentos” do autor. Ou seja, há um diálogo entre a teoria de linguagem proposta nesta pesquisa e a teoria de argumentação. $\mathrm{O}$ autor seleciona para o seu texto um potencial de significados de linguagem que parte de escolhas sistêmicas de múltiplas possibilidades de acessos a diferentes sistemas semióticos e um potencial de significados argumentativos que é construído de acordo com as escolhas de estratégias de argumentação para criar um determinado posicionamento.

De acordo com a análise proposta nesta pesquisa, percebo que essa relação entre o potencial de significados e o potencial argumentativo é importante para realçar que os significados são realizados de tal maneira que qualquer modificação afetará todos os seus níveis.

Entendemos, aqui, que as escolhas dos autores - tanto argumentativas como de linguagem - são paradigmáticas, e, como disse, podem ser intencionais ou não. Cabe a nós, professores, atuar de maneira mais incisiva na defesa de um maior espaço da abordagem Sistêmico-Funcional e da Avaliatividade nas salas de aula, para que os autores tenham a oportunidade de atuar nos textos de maneira mais consciente, percebendo toda a intencionalidade que permeia a linguagem. Concluímos que a Avaliatividade contribuí para a Argumentação quando entendemos que existem possíveis novas estratégias que repousam nas escolhas argumentativas, semânticas e lexicogramaticais feitas pelos autores.

Acredito estar contribuindo para o ensino de produção textual quando proponho a possibilidade de interface e de diálogo entre a teoria de linguagem proposta pela Linguística Sistêmico-Funcional, o Sistema da Avaliatividade e a teoria da Argumentação para potencializar o posicionamento autoral dos alunos, nos textos; principalmente, por afastar a análise da Argumentação dos aspectos puramente textuais e aproximá-la do significado interpessoal, avaliando-a sob o ponto de vista semântico.

Não podemos esquecer que a LSF é uma teoria de análise do discurso e, dessa maneira, pode e deve ser ensinada nas salas de aula. Os resultados da 
análise indicam que os recursos da Avaliatividade atuam como potencializadores da construção do posicionamento do autor e, além disso, apontam para a necessidade de fazermos uso da abordagem Sistêmico-Funcional e da Avaliatividade em sala de aula, no ensino-aprendizagem de Língua Portuguesa, principalmente no que se refere à Produção Textual.

Se o que, inconscientemente, os alunos são capazes de fazer em termos de construção argumentativa fosse formalmente apresentado em nossa prática docente, no dia a dia, em sala de aula, talvez tivéssemos escritores ainda mais engajados com seus discursos. Dessa maneira, sugiro que para a possível ampliação de uma identidade autoral consciente nos alunos se faça uso da LSF e da Avaliatividade na prática docente de Língua Portuguesa.

Sabemos que os autores destes textos são expostos a aulas de Produção Textual, e praticam a produção de redações, o que pode possibilitar um mais fácil reconhecimento das estratégias argumentativas. Seria ainda mais conveniente que os autores pudessem fazer uso consciente dos recursos da Avaliatividade em seus textos para experimentar e alcançar novos potenciais de significados argumentativos, criando ainda novos potenciais de posicionamentos.

Como citei na introdução deste trabalho, na medida em que investigamos novas reflexões são feitas e novas propostas, possibilidades, escolhas e contribuições vão se matizando e alcançando outros espaços de reflexão, mas, com isso, também se apresentam algumas limitações desta pesquisa, o que pode motivar novos encaminhamentos.

Há algumas limitações desta pesquisa que se inserem em aspectos contextuais, principalmente. Ainda que este estudo tenha sido proposto para alunos de cinco grupos diferentes, a investigação foi conduzida com alunos de uma mesma instituição, e apenas uma série escolar, o que pode restringir os resultados a apenas um contexto, principalmente se pensarmos que são alunos que têm aulas de Produção Textual e possuem alguma experiência com o texto dissertativo-argumentativo.

Além disso, seria interessante levar as questões desta pesquisa a outros cenários que envolvam textos diferentes do tipo dissertativo-argumentativo para que possamos observar a Avaliatividade atuando em outros tipos de texto que, embora não sejam argumentativos, do mesmo modo, partem do posicionamento do autor, como, por exemplo, é o texto descritivo. 
Ainda que o aspecto argumentativo não seja um atributo do texto descritivo, quando o autor decide descrever, por exemplo, um ambiente ou um personagem, fará escolhas lexicogramaticais paradigmáticas. Se um autor escolhe caracterizar um personagem como dono de cabelos lindos ou de uma personalidade marcante e caráter irrepreensível, estará fazendo uso de recursos avaliativos para tal. Seria interessante entender que recursos da Avaliatividade são mais recorrentes e por que, que tipo de autor se constrói no texto ou ainda que tipo de leitor o autor constrói para consumidor do seu texto.

A pergunta elaborada para a proposta de redação deste trabalho trazia explicitamente a solicitação para que o aluno se posicionasse a respeito do tema do ensino da escrita para a inclusão social. Igualmente seria relevante trabalhar com outro tipo proposta, talvez sem o uso de uma pergunta, ou de maneira menos incisiva, para verificar se ela geraria outro tipo de posicionamento. A Avaliatividade poderia, neste caso, ser utilizada como estratégia de potencialização de posicionamentos em outros temas de redação que não levassem tanto a esta colocação indicada pela questão proposta na redação?

Da mesma maneira, deve-se considerar a possibilidade de futuros encaminhamentos para esta pesquisa, como trabalhar com a elaboração de uma grade de correção (cf. capítulo 1, nota de rodapé $\mathrm{n}^{0} 3$, p. 14) que tivesse por base os pressupostos da LSF e propor o ensino de produção textual com base nos recursos da Avaliatividade.

Implicações pedagógicas surgem da natureza deste trabalho que também tem a intenção de refletir a prática em sala de aula, portanto, propor aos alunos o exercício da produção textual de maneira a trabalharem com mais propriedade o potencial argumentativo de seus textos e levar o autor a ter a consciência de que suas escolhas criam instanciações específicas e podem ser mais adequadas em determinados textos, pode significar um ganho para a educação.

Comecei este trabalho por acreditar que quando escrevemos também nos inscrevemos no texto, incorporamos nossos princípios ao texto, lavramos nossos ideais, imprimimos nossos valores e gravamos nossas digitais como autores. Espero que a minha curiosidade e motivação para esta pesquisa encontre novos caminhos e possa ser compartilhada, principalmente com outros professores, pesquisadores e alunos. Encerro este estudo com a certeza de que quando um indivíduo é capaz de argumentar de maneira consciente, pode se sentir “em pé de 
igualdade” na sociedade, se insere em diferentes contextos, se inscreve em sua comunidade, e faz valer a sua voz. Consequentemente, a apropriação da escrita como uma ferramenta que pode levar o autor a alcançar outros propósitos comunicativos (que não apenas a reprodução do modelo de um tipo de texto específico) é uma importante aliada no exercício da cidadania. 


\section{Referências bibliográficas}

ABREU. A.S. A arte de argumentar: Gerenciando Razão e Emoção. São Paulo: Ateliê Editorial, 2003.

Acordo ortográfico da Língua Portuguesa. 1990.

ANDRÉ, M.E. Etnografia da prática escolar. Campinas: Papirus, 2001.

ARISTÓTELES. Arte retórica e arte poética. $17^{\mathrm{a}}$ ed. Rio de Janeiro: Ediouro, 2005.

APPOLINÁRIO, F. Dicionário de metodologia científica: um guia para a produção do conhecimento científico. São Paulo, Atlas, 2009.

AULETE, F.C. e VALENTE, A.L. Dicionário contemporâneo da língua portuguesa Caldas Aulete, Edição brasileira original: Hamílcar de Garcia. Versão Digital, 2005.

BRETON, P. A argumentação na comunicação. Bauru, São Paulo: EDUSC, 1999.

BAKHTIN, M. Marxismo e filosofia da linguagem. São Paulo: Hucitec, 1992. [1988]

Estética da Criação Verbal. São Paulo: Martins Fontes, 1997.

Os gêneros do discurso. In: . Estética da criação verbal. São Paulo:

Matins Fontes, p. 261-306, 2003.

BARTHES, R. O prazer do texto. São Paulo: Ed. Perspectiva, 2002.

BORTON-RICARDO, S.M. O professor pesquisador: introdução à pesquisa qualitativa. São Paulo: Parábola, 2008.

CALDEIRA, J.R. A redação de vestibular como gênero: configuração textual e processo social. 2006. Dissertação de Mestrado. Departamento de Letras, Pontifícia Universidade Católica do Rio de Janeiro.

CARDOSO, C.J. A socioconstrução do texto escrito: uma perspectiva longitudinal. 2000. Tese. Faculdade de Educação da Universidade Federal de Minas Gerais, Belo Horizonte.

CELLARD, A. A análise documental. In: POUPART, J. et al. A pesquisa qualitativa: enfoques epistemológicos e metodológicos. Petrópolis, Vozes, 2008. 
DENZIN, N.K.; LINCOLN, Y.S. O planejamento da pesquisa qualitativa: teorias e abordagens. Porto Alegre: Artmed: Bookman, 2006.

DUCROT, O.; BARBAULT, M.C.; Colab.; DEPRESLE, J; Provar e dizer: linguagem e lógica. São Paulo: Global, 1981.

EGGINS, S. An introduction to Systemic Functional Linguistics. New York: Continuum, 2004.

ERICKSON, F. Ethnographic microanalysis of interaction. In M. LeCompte, W. Millroy, \& J. Preissle (Eds.), The handbook of qualitative research in education (pp. 201-225). New York: Academic, 1992.

FIORIN, J.L.; SAVIOLI, F.P. Para entender o texto: leitura e redação. $16^{\mathrm{a}}$ ed. São Paulo: Editora Ática, 1996.

GOUVEIA. Escrita e ensino: Para além da gramática, com a gramática. Revista de documentação de estudos em linguística teórica e aplicada. 2009.

GRIZE, J.-B. Logique et language. Paris, Ophrys, 1990.

HALLIDAY, M.A.K. Language as social semiotic: the social interpretation of language and meaning. London: Edward Arnold, 1978.

An Introduction to Functional Grammar. $2^{\text {a }}$ ed. London: Edward Arnold, p. ix-xxv, 1994.

Language in a social perspective. In: Coupland, Nikolas and Jaworki, Adam. Sociolinguistics. A reader. New York: St. Martins’s Press, 1997. p. 31-38

HALLIDAY, M.A.K. \& HASAN, R. Language, context and text: Aspects of language in a social-semiotic perspective. Oxford: Oxford University Press, 1989.

HALLIDAY, M.A.K. \& MATTHIESSEN, C.M.I.M. Clause as Representation. In: An Introduction to Functional Grammar. $3^{\mathrm{a}}$ ed. London: Hodder Arnold, p. 169-305, 2004.

Construing experience through meaning: a language-based approach to cognition, London, New York: Cassell. Reviewed by John F. Sowa in Computational Linguistics Vol. 27, Issue 1 (March 2001). Pp. 140-42.

HASAN, R. The structure of a text. IN: M.A.K. HALLIDAY \& R. HASAN (Eds.) Language, context, and text: aspects of language in a social-semiotic perspective. Geelong, Vic: Deakin Unviversity Press. Oxford: OUP. Second Edition, 1989.

HAWAD, H. Tema, sujeito e agente: a voz passiva portuguesa em perspectiva sistêmico-funcional. 2002. Tese de Doutorado. Departamento de Letras, Pontifícia Universidade Católica do Rio de Janeiro.

HELDER, R.R. Como fazer análise documental. Porto, Universidade de Algarve, 2006. 
LINCOLN, Y.S.; DENZIN, N.K. O planejamento da pesquisa qualitativa. Porto Alegre, ARTMED, 2006.

LUDKE, M.; ANDRÉ, M.E. Pesquisa em educação: abordagens qualitativas. São Paulo: EPU: 2001.

MALINOWSKI, B. The Problem of Meaning in Primitive Languages, Supplement I to C.K. Ogden \& I.A. Richards (Eds.) The Meaning of Meaning. New York: Harcourt Brace, 1923.

An Ethnographic Theory of Language, of Coral Gardens and their Magic. Volume 2, London: Allen and Unwin, 1935.

MARTIN, J.R. English Text: system and structure. Amsterdam: Benjamins, 1992.

Beyond exchange: Appraisal Systems in English. In: Huston, S.; Thompson, G. (Eds.). Evaluative Texts. Oxford: Oxford University Press, 2000.

MARTIN, J.R. \& WHITE, P.R.R. The language of evaluation: appraisal in English. New York: Palgrave Macmillan, 2005.

MEURER, J.L. Texto e contexto na linguística sistêmico-funcional: estratificação, Metafunção e outros parâmetros para o estudo da linguagem. 2006. Tese de Doutorado. Departamento de Letras, Pontifícia Universidade Católica de São Paulo.

MILLER, C.R. [1984] Genre as social action. In FREEDMAN, A \& MEDWAY, P. (eds.), Learning and teaching genres. Portsmouth, N H: Heinemann, 1994.

NEVES. M.H.M. A gramática funcional. $3^{\mathrm{a}}$ ed. São Paulo: Martins Fontes, 2004. [São Paulo: Ática, 1997].

NETO, O.C. O trabalho de campo como descoberta e criação. In: MINAYO, M. C. (Org.); DESLANDES, S.; NETO, O.; GOMES, R. Pesquisa social: teoria, método e criatividade. Petrópolis: Vozes, 2003.

NÓBREGA, A.N.A. Narrativas e avaliação no processo de construção do conhecimento pedagógico: abordagem sociocultural e sociossemiótica. 2009. Tese de Doutorado. Departamento de Letras, Pontifícia Universidade Católica do Rio de Janeiro.

PERELMAN, C.; OLBRECHTS-TYTECA.Tratado da argumentação: a nova retórica. São Paulo: Martins Fontes, 1999 [2005].

PILAR, J. A redação de vestibular como gênero, In.. Orgs. MEURER, J.L.; MOTTA-ROTH, D. Gêneros textuais e práticas discursivas: subsídios para o ensino da linguagem, EDUSC - Bauru, SP, 2002.

RAMOS. M.O.M. A nominalização de processos verbais: perspectiva sistêmicofuncional da produção textual em contextos escolares. 2011. Dissertação de 
Mestrado. Departamento de Letras, Pontifícia Universidade Católica do Rio de Janeiro.

UNSWORTH, L. Researching language in schools and communities. New York: Continuum, 2000.

VIAN JR. O..; SOUZA, A.A.; ALMEIDA, F. (Orgs.). A linguagem da avaliação em língua portuguesa. Estudos sistêmicofuncionais com base no sistema da avaliatividade. São Carlos: Pedro \& João Editores, 2010.

WHITE, P. Valoração - A linguagem da avaliação e da perspectiva. Trad. D.C.F. Linguagem em (Dis)curso. LemD, Tubarão, v. 4, n. esp, p. 177 - 205, 2004.

WHITE, P. An introductory tour through appraisal theory One. Disponível em: <www.grammatics.com/appraisal>. Acesso em: 24 jun. 2012.

WILDE, O. The Soul of Man Under Socialism. Forgotten Books, 1950.

WILSON, C.D.R.J. Relações interpessoais em um fórum de discussão online: a perspectiva sistêmico-funcional em práticas discursivas de ensino à distância. 2008. Tese de Doutorado. Departamento de Letras, Pontifícia Universidade Católica do Rio de Janeiro.

THOMPSON, G. Introducing Functional Grammar. London: Arnold, 1996. 2. ed. London: Arnold, 2004. 


\title{
Anexos
}

\section{Anexo 1 - Redação 1. Título: Canetas e inclusão social}

\author{
corratar indunto tracici
}

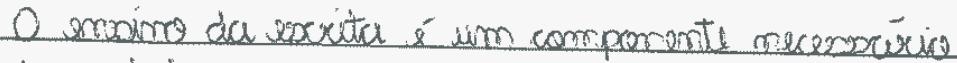

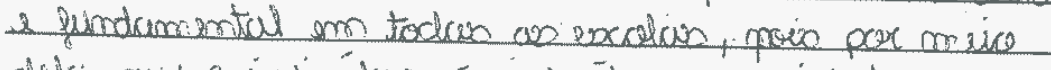

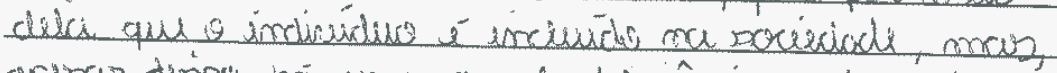

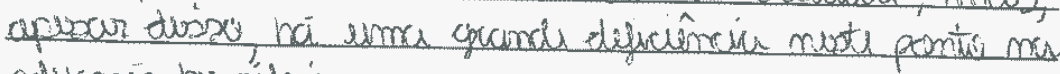
odviacric brusilewir.

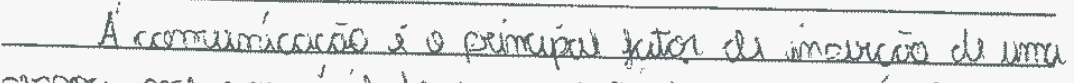

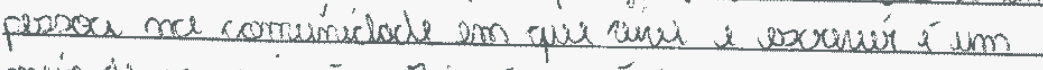

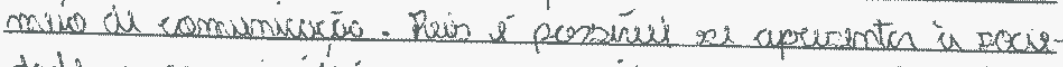

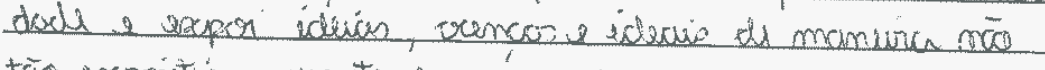

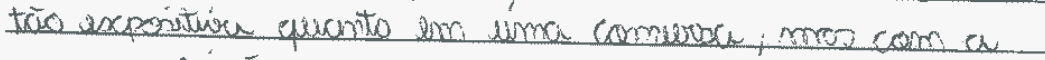

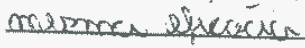

Somal cussion, poode-ns compresender im ports o moti-

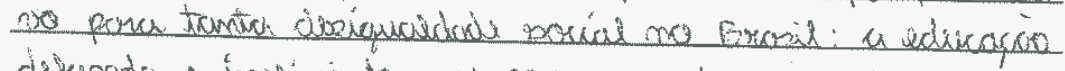

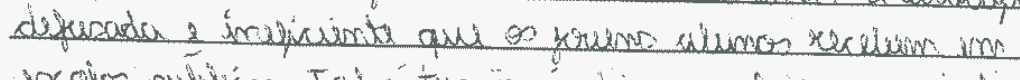

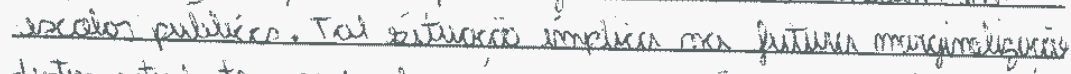

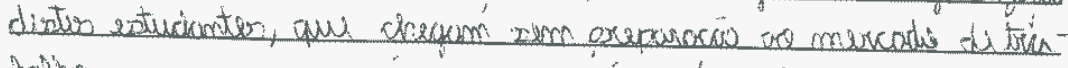

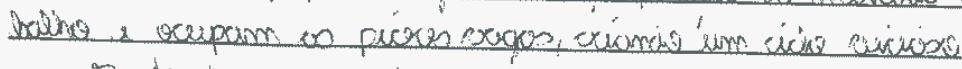

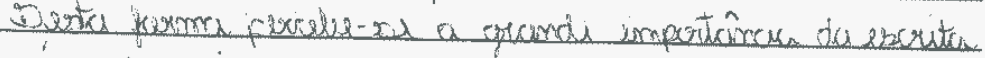

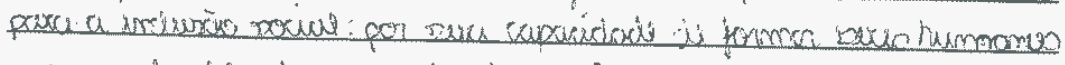

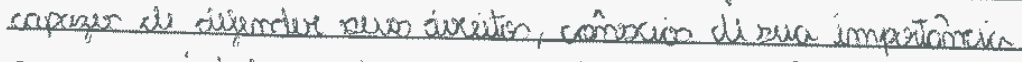

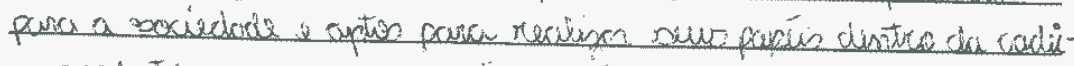

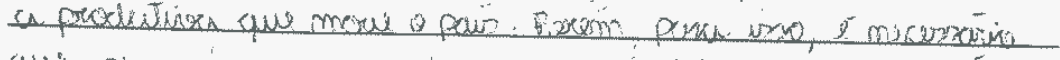

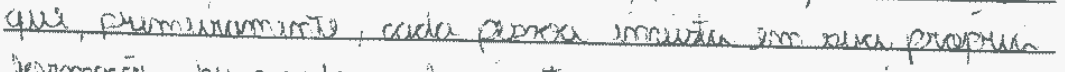

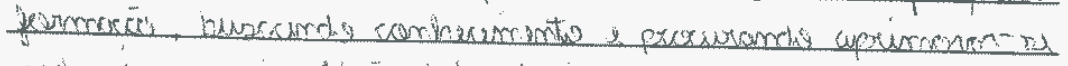

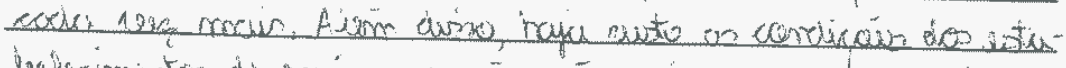

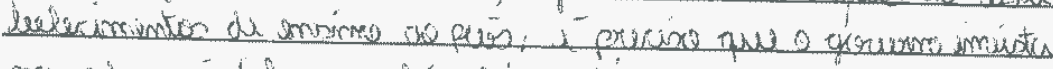

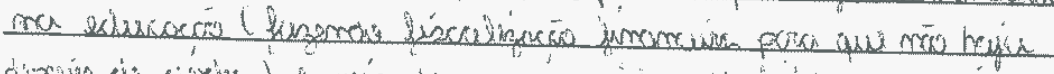

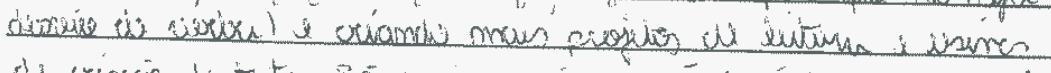

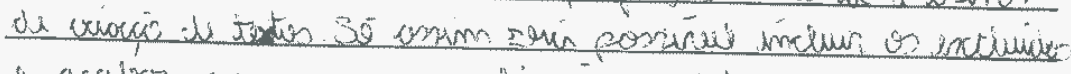

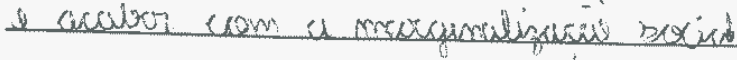




\title{
Anexo 2 - Redação 2. Título: A importância da leitura e seus reflexos
}

\author{
Impertancia da beitua esus riflexos
}

A litura é imprescindínel pura o mundo en que vi-

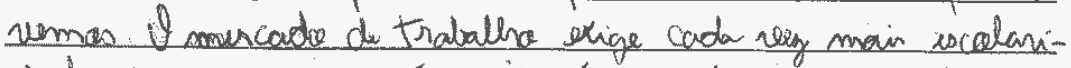
dade de seus funcionários. Porém a situacáo de sicolaridade em musitar instituñois vai de enconto a enta necisidade.

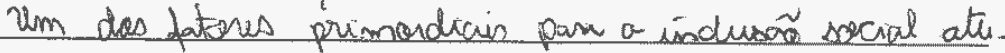
omente í saler len e escresur. Além disso, outro aspecto impantante í saber interpretar a litura- Sindo assim a indivícho que souber ler, escrerver el interpretan Terá mair facilidade para incluin-se socialmente. Além da inilusía cal a mercade de Trabalho

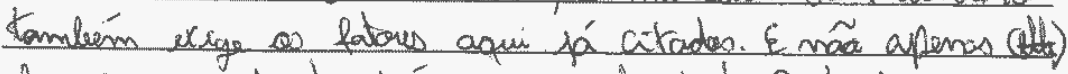
Lles Q mercada tantúm exige escolaridade. Pertanto a $C_{-}-$ dadä́ oue almiza uma loa quahidade de vida secassita fraquintar a esicala e stibizar a leitura a escrita a seu fargon.

Entretento a mecussidade de secolaridode ná contig com a situocáa de muitas iñotituricás públicas em nos to paús. Logo, a vontade do cidadäo se excoularizar Tem que se aliar a milhoria da qualidade des ensims, para que a aumente grau de exala. ridade mo Bnusil. Por fim é possineil constatar que a litura í de extrema impontancia para a incluaía social, togo, tá que lietura estó divetamente legado a escolevidade, í também importante para empergan-se no mercado de trabalhe 


\section{Anexo 3 - Redação 3. Título: A escrita social}

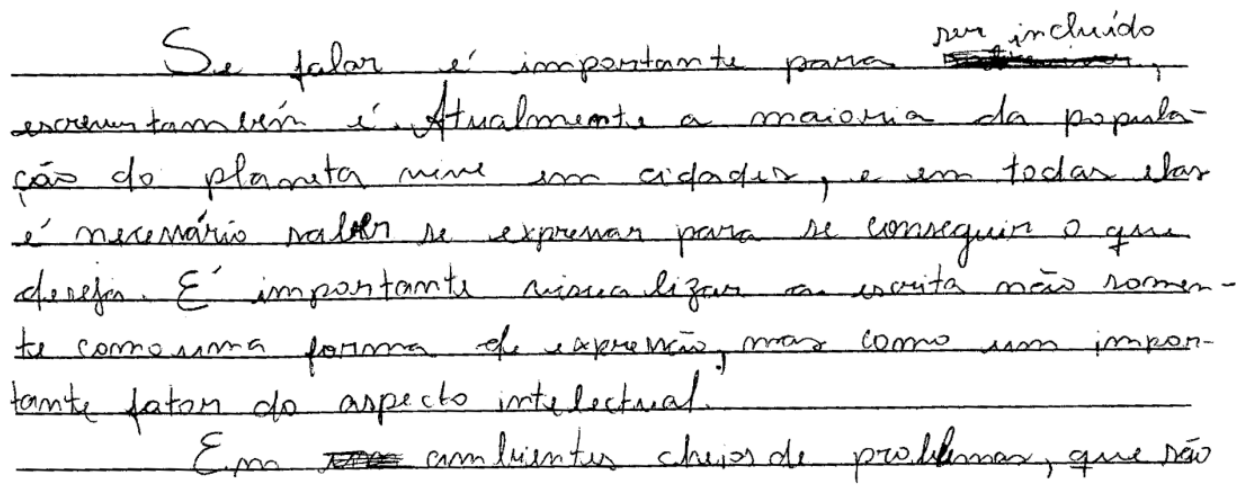

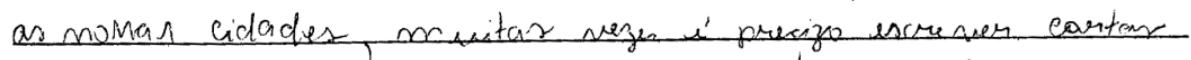
époliticor eacutran antopidader + No Brazil, a maion parte das reclarmancós e reiviondicancos crontece pou maio deprotedtor on discramoin orain. Ema incapacidagle de excever renela suma deficiência ma comunicucāoo,

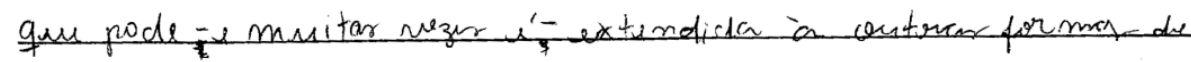

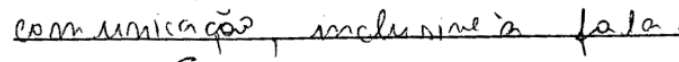
Se a imcompetémcia ma escrita pode re mehanioncom-

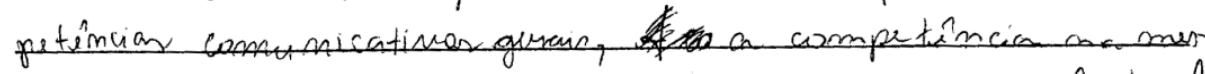
mov revela tameu'm rom mader capacidade inte lectual; que s'importants, gés que momor sever intulectuais

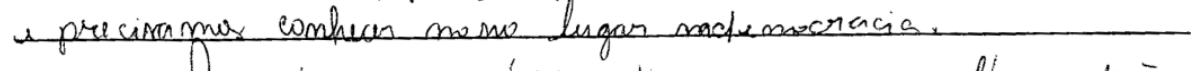
Desamto meris rápido ationgir mor sam alto peadriñ na lrerita son toda a rociedade, mais rápido ressmos

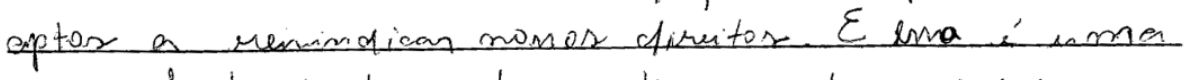

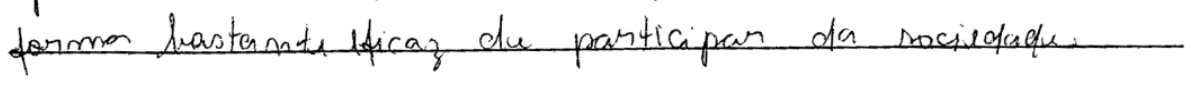




\section{Anexo 4 - Redação 4. Título: O ciclo da cultura}

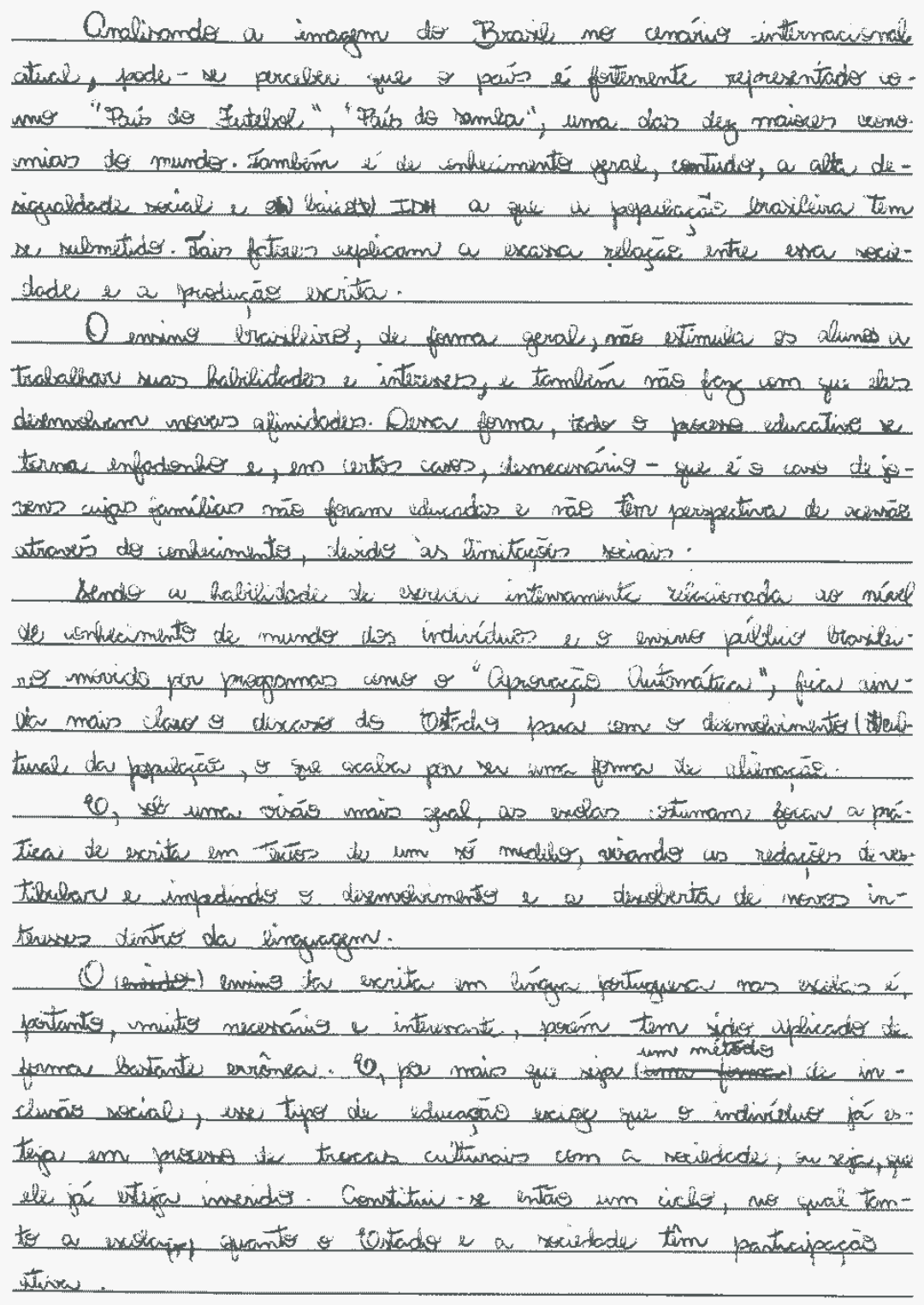




\section{Anexo 5 - Redação 5. Título: A importância da escrita}

Limpotáncia da escrita

Ser e secrever sem ño importante Ló prana se tew una boa formagos, E' neresnário tambeń pana aue se possar vorken influéneia sobre o mais social um que se vine. Forem, os lacoles na dö a merveida atença a ferodurös texture.

Para que se pasva lar e excrever bean, \& necestósio um acompenhomento dusde os primeinos séries do peñodo vacolan. Um aluno mä consegue produnzir bowar tutas se nä tiver aulas de sedacäs prequentemente em sew colegio, que na maionia dos veres. ferece essas avios no enaino medio, mos ná con a dervida intensidade, visando nä tó un bom preparo para a vida ocademico. como trambern um preparo pora a induras social do indiríduo, que quondo bem prepo.

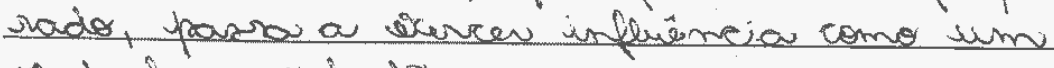
serdadines idadäs.

Forianto, í de suma importáncios que co insiturivo de ensino deen desde redo umo brace, com o objuctive du forman bons profistionais e persoor que partiven como idadoss. 


\title{
Anexo 6 - Redação 6. Título: O caminho para entrar na sociedade
}

\author{
U commlio para entrar na saiedade
}

Uma das grondes importôncias para se encluir na sociedode, de modo que se perssa, fulczar, questio nar pelos noxsos interesser, peronte a sociedode iter o dominio da litura e excita. As oes como essas noo proporionen inúmeron recursos, cormo um hom dexmichiminto na falla para uma entravista de empreg, as sim como a excrita ayuda no elaboriz cáo de uma radocos por exemplo.

Oprocesso de sexializar o indivíduocionseza desde cedo nas excelan a pevitir dos aulas de língua por tuguesa que se inicia a poimuróo da exrita, gue É functornental poir ayuda na labozocóo tertual. Por ins é impectont se dedican à essas aúvan porque as mesmas sas respemróneir na gromde misidia pelo ducess nas áricas de traballo

noemo adquirindo muita experiênxioyuma boa faruldade 2 ensino médio completo, tern

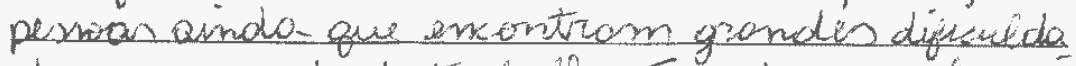
des no mercodo de tratol iho. Imogina aqueles qué noo dä a impertioncia necessa itia para o estudo? Ester poderöo futuromente encontiver barrevias no sen oficio on terão a soiste. de nōo necessítar de uma formácís adequada. contude impertionte ressactor e gronde 20 ar de cada aula realizala na escola porquí éatrové delas que cresomon e sentiremos inclusos na socied ade. 


\section{Anexo 7 - Redação 7. Título: Educação e evolução}

\section{Tducocỗo e Culucõô}

rida de um indivíduo, ela deve ner desenwlida seriamente pelas autoridoder para. que o individuo venha desenwever e atwar com rucresso sobre a soriedade. Lima boa educocia proviém de uma leitura conbiente, em que tamberm, deve - re saber excrever. Tais fotores sä de extrema Limportência para a inclusa sorial do sujeits ma rociedode.

Im menturm lugar ds unundo pode ingressar unuma grande empresa se nô estiver inserido muma formacäe odequada por esse motivo os governantes denem se importar mairs em investimentos e profetos para melhorias na educocpö, de que, em lipa do Munds demontrondo a outros paises que o Brasil $e^{-} \theta$ paŕ do futwor, por outow lodo, a realiolode mão $e^{\prime}$ essiar, e sim. que a leitura e escita estấ coda vez mais precárias atwalmente.

O Brasil deve ser um paú de everuques e perceber que unâ há desenvolumento econômico, a partir do momento que nos existe recursos para meerwrias na educa. cor, toales tem direits à inclusaó sorial tronsformonds videras e rostumes de cocla win 


\title{
Anexo 8 - Redação 8. Título: Escrever bem é o produto da leitura
}

\author{
Esauver bem é o produto da levteura
}

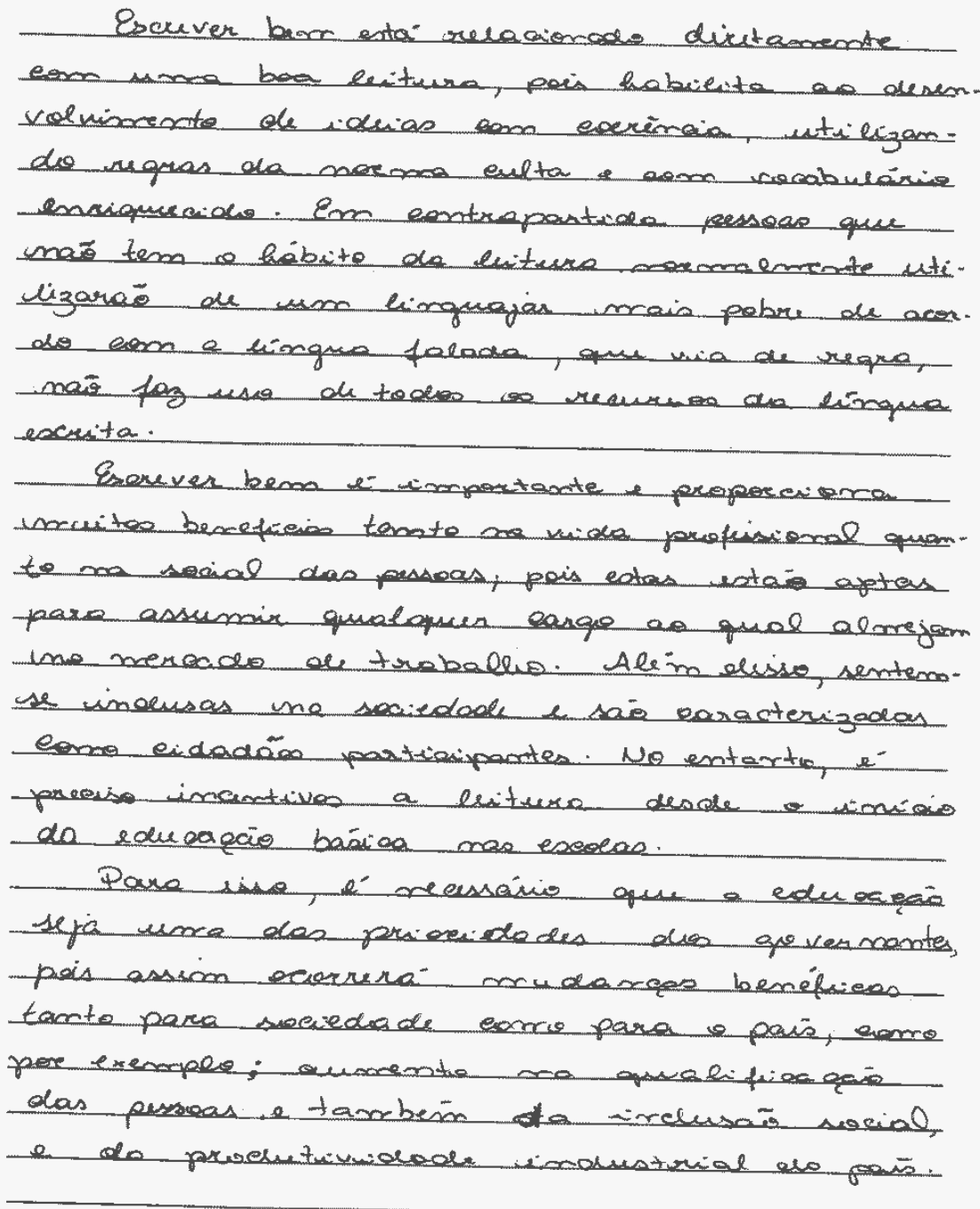


Anexo 9 - Redação 9. Título: A importância da escrita

Aimportáncia da escrita

A falta de incentivo apsestudos o de investimintos na inproestrutura ráo aloumas das lausas de \& Brasil ter un dos poren niveis de excalaridude do mundo. Sese faz com que a eserita perca sua importáncia e fique em segundo plano, no que dig respeito a incluzão socia l. Além disso há muitos somplos de pesoces no paŕa que conseguem ascender soriolmente.

Gatual mercado de trabalho preza mais pela oxperéênciou da pesso no emprego do que a nos do estudo, descolorizando este último e per consequéncia, desvalorizando os encos de apien. dingedo dada língua portuguesa.

Além disso, a falta de investimentos em infras trutura e a falta de incentivo aos estudos far com oue propessoses ñar Lenham material paraministrar una droa aula e com isso, as excolas acalram fiomdo mais vazias.

Leutro fator que diminui a importánsia da excrita és de quer un grande numeros de pessoas conslgui ascender vocialmente se incluir na sociedade sem precisar dela, lomo éo easo de muitos jogadores de futelor em quem a maionia das erionsar se espelham, de muitos poleticos, Causando un sentimento de infustica ras pessoas deaccaram muitos anos dos suar vidas ao etudo e recebem finameiraumente por oxem plo, menos do que esses indivédus

Épreciso portanto que a sociedrde reveia seus conceitos sobre sque ér importante na vida e tize perceba que as pessow que tem contéído devem ser mais valorizada dentro do soriedods 
Anexo 10 - Redação 10. Título: Chave para o conhecimento

Chavie arn o combiciminte

Sabir dominar a scrita de sus prógerir lingur í dyo de

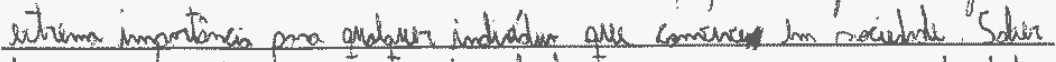

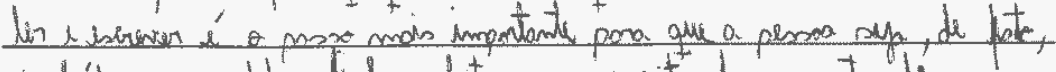

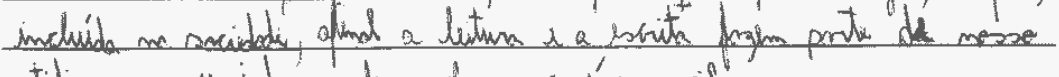

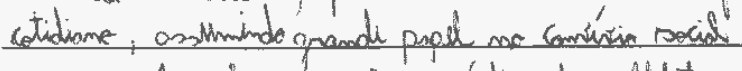

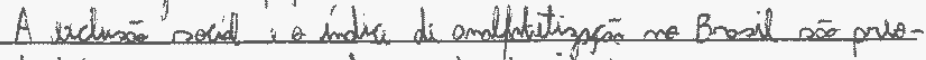

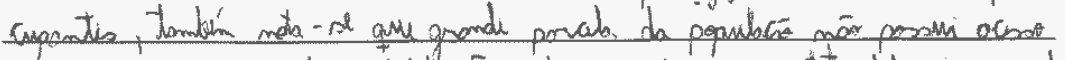

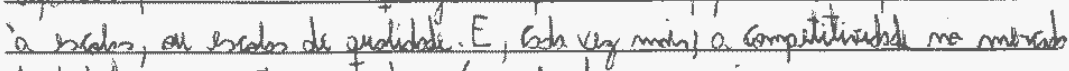

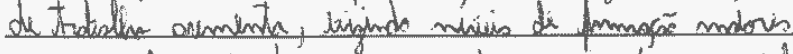

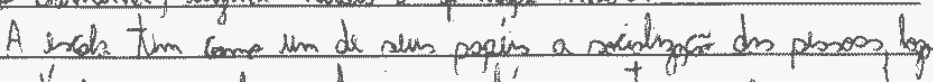

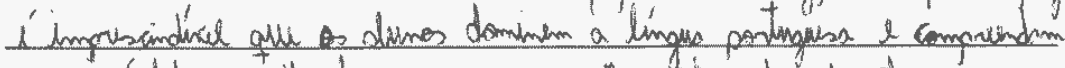

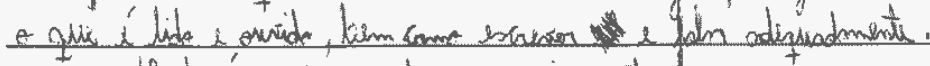

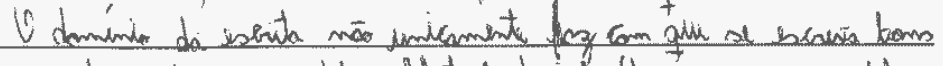

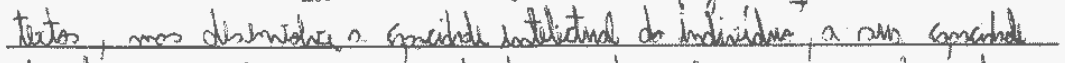

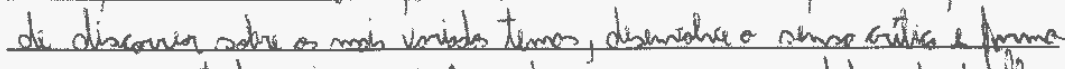

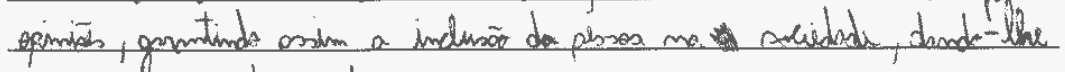

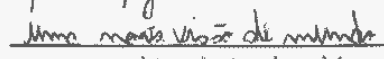

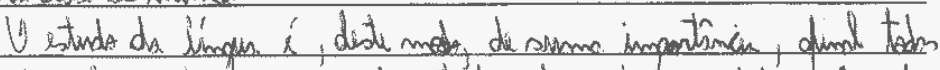

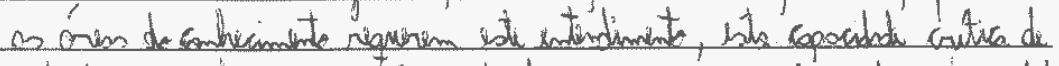

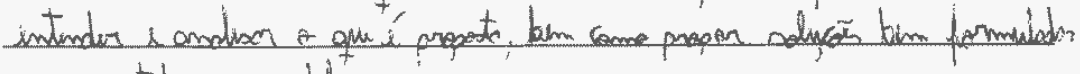
Laperesentidon es protilimas. 
Anexo 11 - Redação 11. Título: Inclusão social

Inclusão Social

Vivemos em uma sociedade, onde as pessoas sao julgadas de acordo com sua escolaridade, onde pessoas que intelizmente, $n a$ maioria das vezzes por cavsa da pobreza, nas possuem oportunidade de ter um bom ensino ov näo consegerem concluir os estudos como na maioria dos casos; serid justo usar a escolaridade como um método para a inclusa social?

Como todos sabem, a pobreza ateta grande parte da sociedade brasiloira, e muitas destas famí lias obrigam os filhos mais velhes a trabalharem desde cedo para ajudarem seus pais a scestentar a casa, e com isse muitos destes jovens. sàe obrigados a largarem os estudos.

Além disso, todos as cidadãos possuem o direito de estudar, sendo do governo a responsabilidade de has proporcionar esse direito, e nen hum cidadáo pode ser considerado culpado de o govenno não ter cumprido as soas obrigaqoes com o povo. Cucluese então, que apenas a taxa de escolaridade náo pode ser considerado uma forma justa, e impor tantei para inclusão social, pois nentum cidadáo deve ser considerado culpado por ter hascido em situaques procárias, ou por nä ter recebide do geverno algo que é considerado um direito de todos os cidadáos. 


\section{Anexo 12 - Redação 12. Título: O valor atemporal do ensino sistemático}

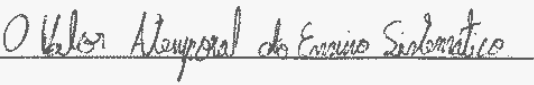

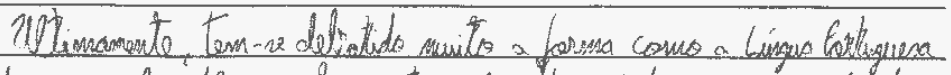

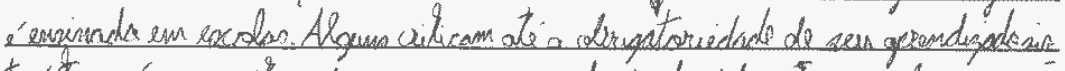

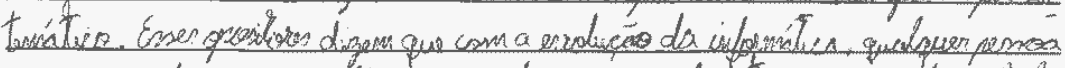

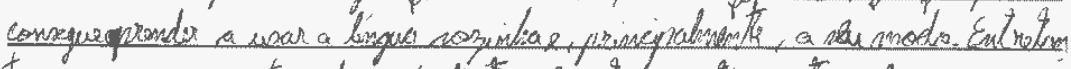

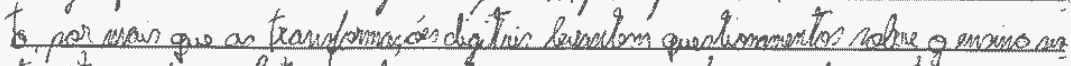

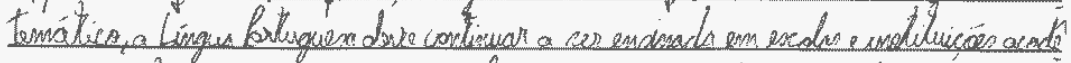

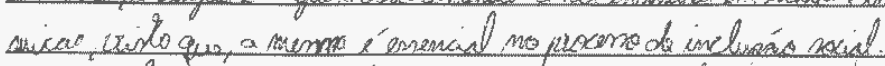

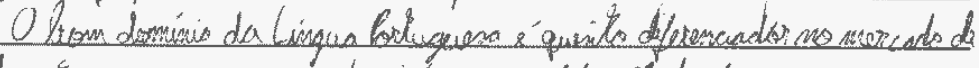

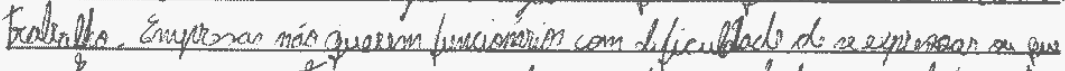

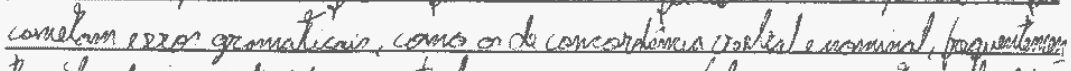

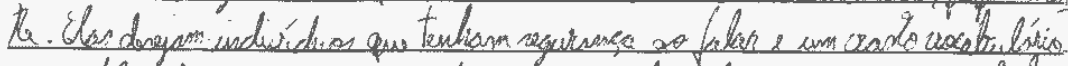

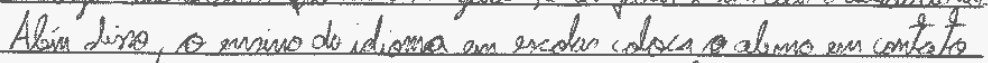

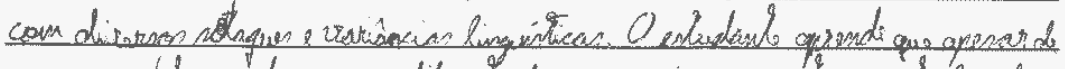

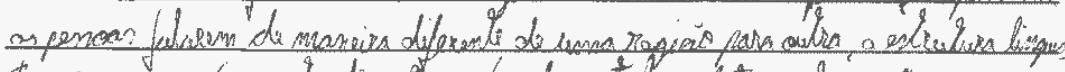

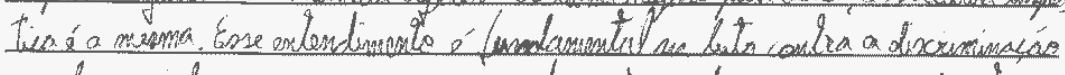

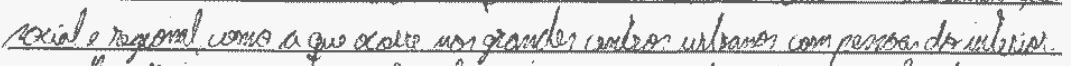

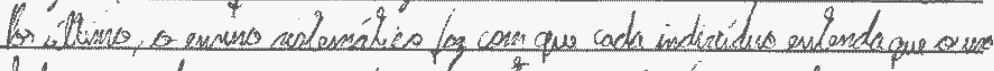

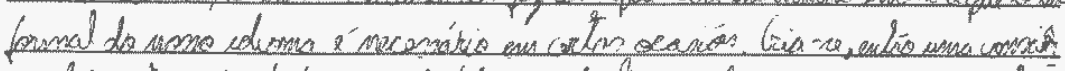

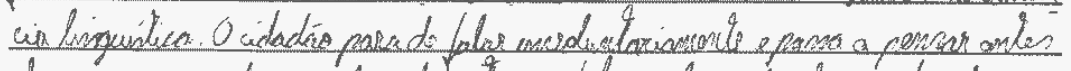

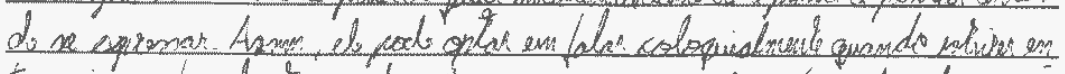

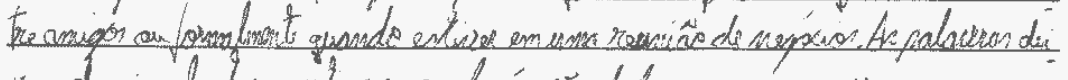

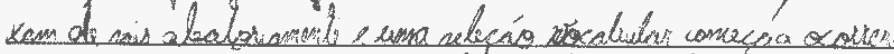

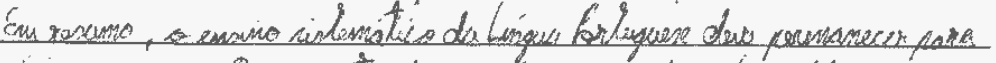

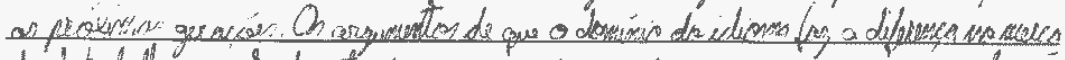

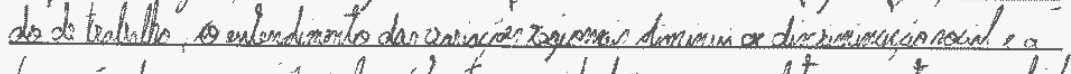

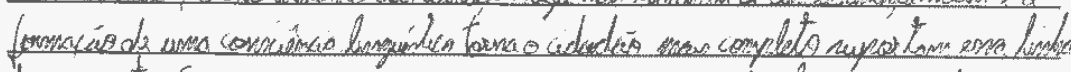

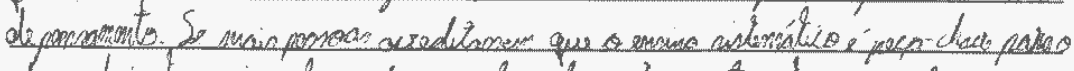

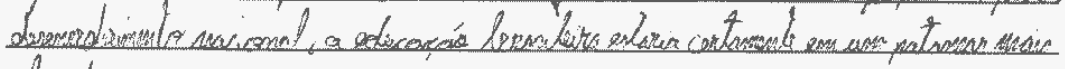
eleerds 


\title{
Anexo 13 - Redação 13. Título: Os reflexos positivos da capacidade de escrita
}

\author{
Os reflexes poritives da capacidade de escrita
}

A importâmia de desenvoluer a sappacidade de vxcrita í cada

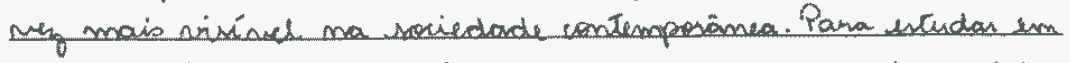
una unstituicāas de enxino unperion, por uxemplo, í sxigida gpande backilidade de intexpretor a produngin tentes. A excrita

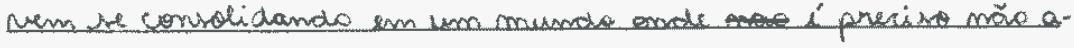

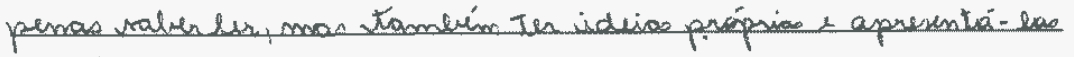
erm forma de texto excrito.

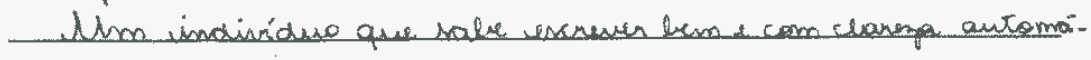
ticamente adquire ves laneng Tombin as ve comumicas com Q outro. Assim. manter un velacionamento con outros pesso be torma mair fácil e mais simples. A halilidade as exerita colabora pana a mäo-exclusä́ social pai facilita an nulaciös interpussocis

Les excrener söo concitos atrelados a capacidade intelectual. Isso siegrifisca que un indivíduso lsita entende mais contéśdso, i mair unation i, dessa forma porshi maiones chances de inseris-se me mexado de tral alho. O profissional que lis es

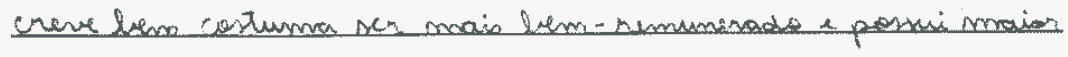
Chome de ver promorido

Como s hálito da excrita influencia ma onalidade, a ar-

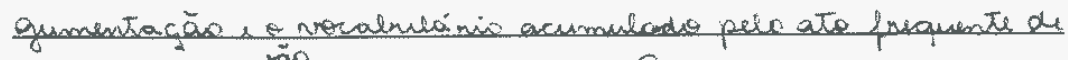

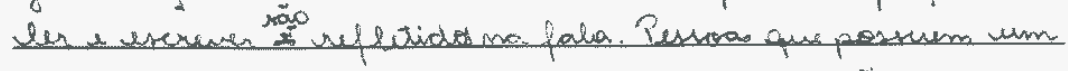

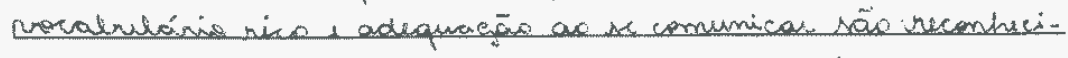

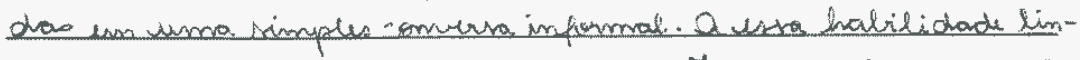

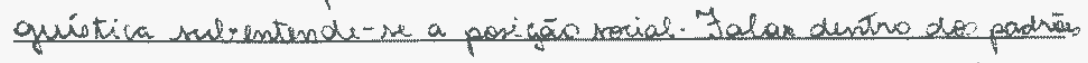
da cooma into denota prestígio e afinmarä individual.

Dessa forma, í vomportanse qus haja, nas excola, vuma

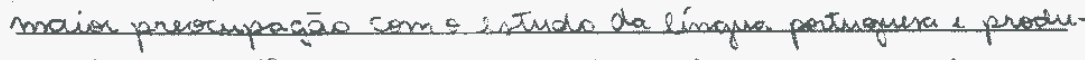

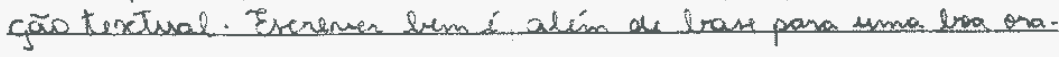

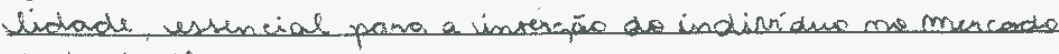
de trabalhes e ma soriediade. 


\section{Anexo 14 - Redação 14. Título: Inclusão e escrita}

A excrita é un marerial de grande importancia para o aprendizado de um ser humano. Como è observado, a exrita é decorrência de una boa leitura, que por sio vez, admite un conhecimento amplo sobre diversos assuntos. Pa ser um lidadáo aruante, o individo precisa manejar multo bem a leitura e a escrita, para opinar ou argumentar en suas comunidas e grupos sociais. Deste modo, a interacão de um individo em grupos sociais, podem inchui-b em uma posiç̄o javorável nesse mesmo meio. Asoim, podendo participar de alguma presidencia de alguma organizacão popular, Liderar passeatas de defesas, a dé mesmo, ser nomeado em grandes posicäes em multinacionais.

É notörio que em nosso país, muitos em nossa sociedade nōo sāo instruidos em Leitura, contukimentos e escrita. Muitos nä possuem nem mesmo uma grodua. câ superior, mas estã em posicöes de gronde importânlie e influéncia. De acordo com esse pensamento, muitos tambem adquiriram conheumentos avantajados, como os profestore, por exemplo, mas nāo possuem werevidos méritos por sua profissāo. Ao conträrio, jao obrigados à exercer sua profissão com muito exforco.
Portanto, mesmo sabendo que a escrita nīo é um meio täo importante para alcançar as mëtas da vida, a inclusão sovial de algum individo, pode vir por atitudes pessoais que o mesmo possa exercer em seu pröprio grupe social. 


\section{Anexo 15 - Redação 15. Título: Objetivos pelo estudo}

Objetivos pelo Estudo.

Todas as pessoas tem um objetivo de vida E para consegui-bo existem diversos caminhos. Ejes Trajetos pedem ser legais an ilegais, porém o unico que so depende da pura vontade Humana é a dos estudos. Para conseguir chegar ate as suas métas, pelo estuda, escrever bem é indispensáveh

A grande quantidade de pesseas existente neste mundo, fazcom que a cada dia mais Homens
fiquem ricos. Esses "Sortudos" sä expostos mundial. mente pela midia, comisso suas vidas passam a ser colaçada pelus demais cidadöes de diversas idades, mas principalmente os jovens. A midia tem como objetive afrair a atencó e com isso muitos vezes divulgam Notúcias sobre as dicas mais problematicas que conseguicam chegar até aquele ponto por um dom ou pela sorte, mas daro com muito esforce. Este fato faz afguns jovens pensacem que nó precisam do estude pra conseguir ter um a vida boa e chegar aos seus objetives, perem o que as no. licias uá mostram 50 as as pessas que chegaram a completar suas metas e viverem muito bem 5o a Travez do estudo. Estos pesscos estō̃ em un vúmero bem maior que as passuidoras de donis e sorte que sas popularizadas pelos meics de comunicacães. A com provacá disto e a Avance teondógico e Humano existente Hoje em dia.

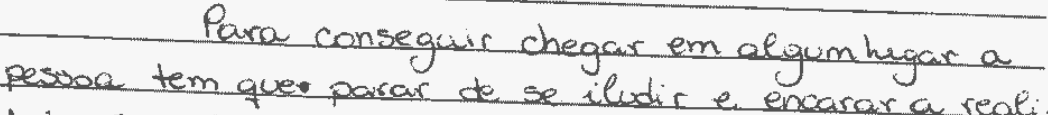
dade. Se nó passexi nentauma Hobilid encarar a reali.

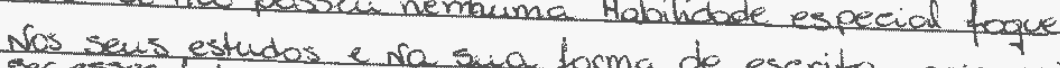
ser esses fatores que iram definir cate onde algerem vai vai chegar. 


\section{Anexo 16 - Proposta de Redação - Tema}

\section{Proposta de redação}

Muito tem se discutido sobre o ensino e uso da escrita formal em língua portuguesa e sua relação com a inclusão social. Os trechos abaixo selecionados tratam desse tema e têm por objetivo ajudá-lo a refletir sobre essa questão:

Ler e escrever faz parte do cotidiano de todas as pessoas, por isso a sua importância no convívio social. É através do uso da leitura e da escrita que o sujeito vai sentir-se incluso na sociedade e ser caracterizado como cidadão participante. Sabemos que um dos responsáveis pela socialização do individuo é a escola.

(adaptado de Santos, A. O. Disponível em www.artigonal.com em 27/01/2012)

“Acho mesmo que escrever é importante, quer dizer, saber escrever. Só que muita gente se esquece que há muitos artistas, jogadores de futebol e até empresários que nem tem o primeiro grau, mas acumulam muitos milhões em suas contas bancárias. E então, eu me pergunto: será que só escrever bem basta? Será que essa é a salvação? Será que é disso que eu preciso? Eu sei que só nascem um ou dois Sócrates e Pelés no mundo, mas quantas outras pessoas se saem bem sem estudar? Isso se chama 'estrela'. Ou a pessoa tem ou não tem."

(A.L.C. Estudante $3^{\circ}$ ano Ensino Médio)

Se, já hoje, uma boa formação no ensino médio é necessária para a plena emancipação e a inserção na força de trabalho, nenhum país pode ter a expectativa de um futuro promissor se empurra para a margem tão grande proporção de seus jovens como nós o fazemos. E, na maioria dos casos, o jovem deixa a escola com um profundo sentimento de não pertença à sociedade e com a autoestima rebaixada, o que afeta profundamente o seu futuro relacionamento com essa mesma sociedade. As consequências estão à vista de todos.

http://blogolitica.blogspot.com/2011/12/ensino-superior-exclusao-privatizacao-e.html

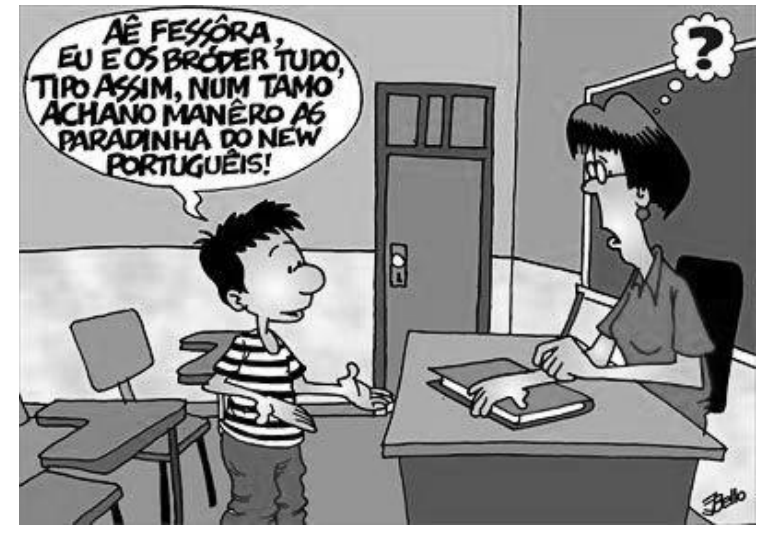

Tendo em vista as perspectivas apresentadas, escreva um texto dissertativoargumentativo, entre 25-30 linhas, refletindo sobre a seguinte questão:

Qual é a sua posição sobre o ensino da escrita em língua portuguesa na escola e sua importância (ou não) para a inclusão social?

Dê um título criativo a seu texto e organize seus argumentos de forma clara, a fim de defender e sustentar seu ponto de vista. 


\title{
Anexo 17 - Autorização de Pesquisa - Do colégio
}

Ric de tarairo. 25 de abril de 2012 .

\begin{abstract}
Assunto: Autorização de pesquisa
Solicito-vos a autorização dessa Divisão de Ensino para a realização de pesquisa vinculada ao projeto "Escrita e inclusão social: Análise da (re)construção identitária no Ensino Médio", desenvolvido no programa de pós-graduação (mestrado) em Estudos da Linguagem da PUC-Rio, do qual a professora ANA PAULA GUIDA TAVARES faz parte, e que esta Coordenação é de parecer positivo.

Solicito-vos, ainda, que os trabalhos desenvolvidos neste Estabelecimento de Ensino sejam incluídos no corpus da pesquisa, sob a condição de que o nome dos alunos e o do Colégio não serão divulgados.
\end{abstract}




\section{Anexo 18 - Autorização de Pesquisa - Dos responsáveis}

Rio de Janeiro, 24 de julho de 2012.

Srs. Pais,

Gostaríamos de solicitar sua autorização para obtenção e análise da redação produzida

pelo(a)

da turma

, do Colégio xxxxx. A produção textual dos alunos contribuirá para a pesquisa Escrita e inclusão social: análise da (re)construção identitária no Ensino Médio, vinculada ao Programa de Pós-Graduação em Estudos da Linguagem da PUC-Rio, que visa investigar a produção textual de alunos do terceiro ano do Ensino Médio, de diferentes contextos escolares, incluindo estabelecimentos de ensino público e particular. Os trabalhos serão incluídos no corpus do estudo, sob a condição de que o nome dos alunos e o da escola não será divulgado.

A proposta de redação tratará de questões voltadas à escrita e inclusão social. Para mais informações sobre a pesquisa, favor entrar em contato com a coordenadora do projeto, Profa. Dra. Adriana Nogueira Nóbrega (adriananobrega@puc-rio.br) e/ou acessar o site www.emeg.net.br.

Atenciosamente,

Adriana Nogueira Accioly Nóbrega

Coordenadora do Projeto de Pesquisa

$\begin{array}{lllllll}\text { Autorizo } & \text { a } & \text { obtenção } & \text { e } & \text { análise } & \text { redação } & \begin{array}{c}\text { produzida } \\ \text { turma }\end{array} \text {, que }\end{array}$

contribuirá para pesquisa sobre escrita escolar, vinculada ao Programa de Pós-Graduação em Estudos da Linguagem da PUC-Rio.

Assinatura do Responsável 


\section{Anexo 19 - Autorização de Pesquisa - Dos participantes}

Nos, alunos da série do Ensino Médio, ano letivo de devidamente matriculados no Colégio/Escola autorizamos a utilização dos trabalhos escolares produzidos por nós para as disciplinas de Língua Portuguesa e Literatura Brasileira, ministradas pela professora para desenvolvimento da pesquisa vinculada ao Projeto de Pesquisa Escrita e inclusão social: análise da (re)construção identitária no Ensino Médio, desenvolvido no Programa de Pós-Graduação em Estudos da Linguagem Pontifícia Universidade Católica do Rio de Janeiro (PUC-Rio), bem como autorizamos a inclusão dos trabalhos no corpus da referida pesquisa, sob a condição de que nossos nomes não serão publicados.

Rio de Janeiro, de de 


\section{Anexo 20 - Matriz de Competências para a Redação do ENEM}

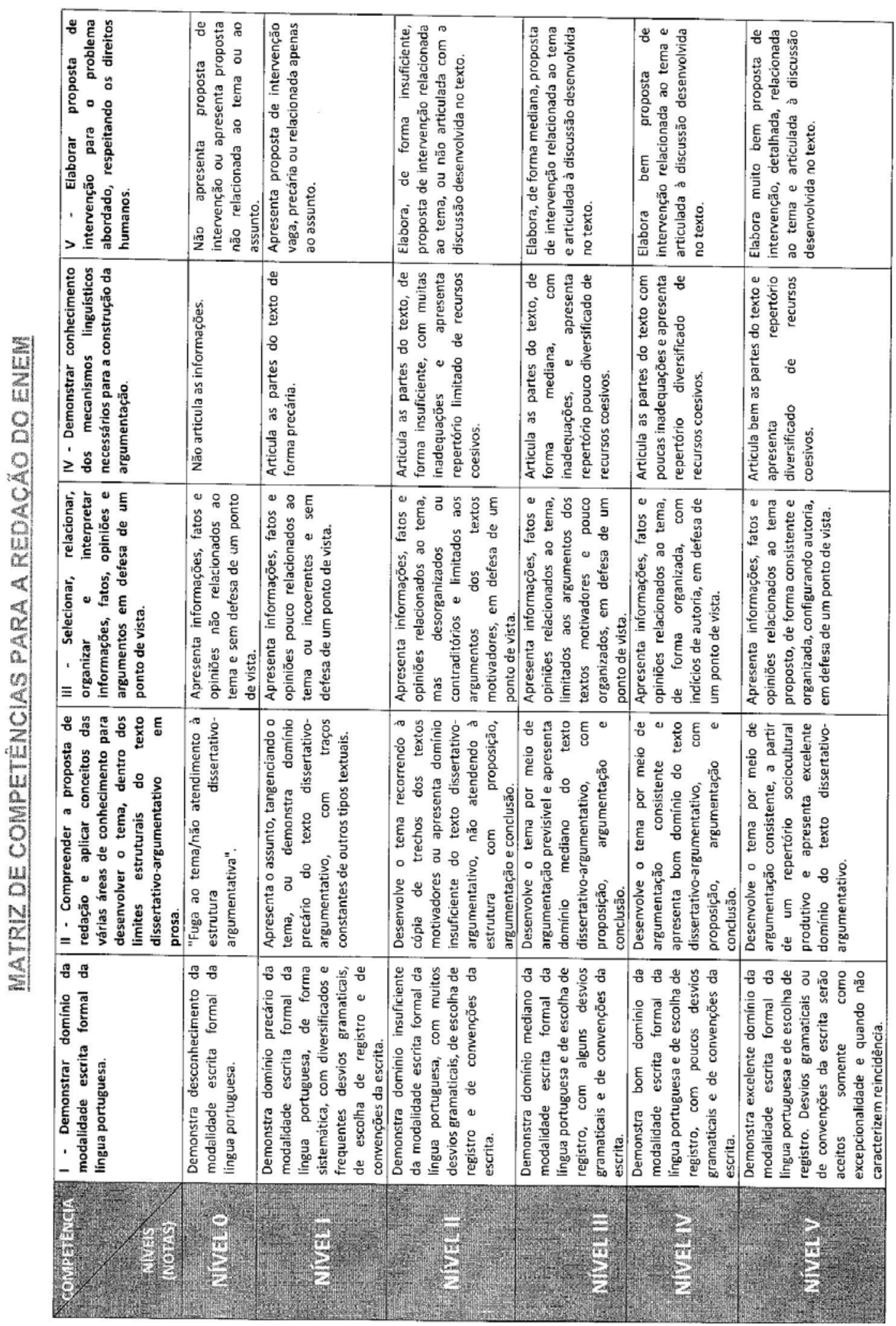

